\title{
Tainted Love: An Increasingly Odd Arbitral Infatuation in Derogation of Sound and Consistent Jurisprudence
}

\author{
Jeffrey W. Stempel
}

infatuate 1: to cause to be foolish: deprive of sound judgment 2: to inspire with a foolish or extravagant love or admiration. ${ }^{1}$

love 1a(1): a strong affection for another arising out of kinship or personal ties ... (3): affection based on admiration, benevolence, or common interests... 2: warm attachment, enthusiasm, or devotion . . . 3a: the object of attachment, devotion, or admiration. ${ }^{2}$

\section{INTRODUCTION: WHAT KIND OF “LOVE” IS THIS?}

Collectively, the U.S. Supreme Court, even if not "in love" with arbitration, appears to at least have a serious attachment to arbitration, subject to revision only in the service of other questionable preferences, such as support for the comparatively richer and more powerful litigant. In that sense, the Court's pronounced, but intellectually inconsistent, preferences for arbitration reflect a reckless, impure, or tainted love rather than the type of mature, realistic affection society generally sets forth as exemplary. ${ }^{3}$ The Court has an unrealistically sanguine view of the wonders of arbitration-so sanguine that it is willing in most cases to

* Doris S. \& Theodore B. Lee Professor of Law, William S. Boyd School of Law, University of Nevada Las Vegas. Thanks to Bill Boyd, Doris Lee, Ted Lee, Ann McGinley, Jim Rogers, and John White as well as to David McClure, Jennifer Anderson, Sabrina Dolson, Elizabeth Ellison, and Jeanne Price for valuable research assistance. Thanks also to Stephen Ware, Christopher Drahozal, and the University of Kansas Law Review for arranging this symposium and its resulting papers.

1. MERriam-Webster's Collegiate Dictionary 597 (10th ed. 1996).

2. Id. at 690. The dictionary definition of "love" has been edited to exclude, among other irrelevant definitions, "attraction based on sexual desire." See id. at 690.

3. A case can be made that in arbitration cases the Court is being dispassionately calculating in its result-orientation and disregard for its professed polestars of sound judicial decision-making. If this is the case, then the Court's performance in arbitration cases is even more contemptible in that it implies blatant misuse of judicial power rather than merely being led astray by arbitration's overall popularity. 
impose arbitration in situations far exceeding those envisioned by the drafters of the Federal Arbitration $\mathrm{Act}^{4}$ and despite significant issues of states' rights, the quality of contract consent, the fairness of the arbitration tribunal, and the overall operation of the dispute resolution system. But at crucial junctures, the Court strains to rein in arbitration when concerned that the arbitration might reach results the Court dislikes or come to resemble litigation-particularly aggregate litigation.

During the past three decades, the U.S. Supreme Court's approach to arbitration disputes has been more than just mere affection for arbitration, but it has also lacked the nuanced understanding and realistic appraisal associated with true love. Rather, the Court's arbitration decisions have reflected something more like a crush or obsession that tends to distort judgment, much as a person in the grip of infatuation views the object of that affection as though it has no faults and with blinders as to the contextual realities surrounding this outpouring of often one-sided emotion. ${ }^{5}$ This uncritical amore for arbitration-and a corresponding, if subconscious, derogation of litigation, at least if resorted to by consumers or employees-has produced a body of Federal Arbitration Act jurisprudence that has been something far short of the U.S. Supreme Court's finest hour.

But at the same time, the Court has resembled the suitor-or perhaps an overbearing parent having "birthed" an expansion of mandatory arbitration - in that it loves something only when it does what is expected. The Court loves arbitration, but only when arbitration functions as the Court thinks it should. Where arbitration seeks to embrace class-wide solutions to disputes, the Court's amore turns almost to anger. ${ }^{7}$ In fact, it seems that the only time the Court does not make

4. 9 U.S.C. §§ 1-16 (2006). The Court in its decisions often uses the short form "FAA" for the Act, which is grating and even confusing. Prior to the modern era of substantial Supreme Court arbitration jurisprudence, the acronym FAA was synonymous with "Federal Aviation Administration," and so it will remain in this article, where the Federal Arbitration Act will be referred to as the "Act" or the "Arbitration Act."

5. This Article talks of the "Court" primarily as a matter of shorthand, recognizing of course that many of the Court's arbitration decisions have divided the Justices, including some 5-4 votes on important issues. To be sure, some Justices are not under the spell of arbitration, but the Court as a whole has been under such a spell from approximately the mid-1980s to the present.

6. See infra notes 167-287 and accompanying text (discussing the Court's mid-1980s move from viewing the Arbitration Act as setting procedural law for federal courts to treating the act as substantive federal law).

7. See infra notes 355-74, 386-423 and accompanying text (discussing Stolt-Nielsen v. AnimalFeeds Int’l Corp., 130 S. Ct. 1758 (2010); AT\&T Mobility LLC v. Concepcion, 131 S. Ct. 1740 (2011)). 
figurative goo-goo eyes about the wonder of arbitration is when the Court thinks that arbitration has become too close to litigation by seeking class-wide treatment of disputes, ${ }^{8}$ which is something largely opposed by the business community with which the Court is arguably even more infatuated. ${ }^{9}$

The Court's embrace of arbitration suggests both infatuation and fickleness. Infatuation, at least in adjudication, is perhaps something worse than blind or even erratic love in that infatuation connotes the type

8. In Concepcion, the Court did both. See supra notes 386-423 and accompanying text. Itrather, five out of nine of its Justices-lavishly praised arbitration while simultaneously suggesting that all of these wonderful attributes of arbitration were eradicated if the arbitration involved classwide treatment of a dispute. See notes 386-423 and accompanying text.

9. See generally ERWIN CHEMERINSKY, THE CONSERVATIVE ASSAULT ON THE CONSTITUTION (2010) (noting the degree to which the Court in recent years has favored business litigants and results generally regarded as ideologically and politically conservative); J. Mitchell Pickerill, Something Old, Something New, Something Borrowed, Something Blue, 49 SANTA Clara L. ReV. 1063, 1063 (2009) ("Since John Roberts assumed the Chief Justiceship, the proportion of the docket devoted to business litigation appears to have increased; outcomes seem more likely to favor business interests; and the Court seems to be more consensual in its pro-business decisions, with divisions seemingly defying the expected conservative-liberal blocs.”); Jeffrey Rosen, Big Business and the Roberts Court, 49 Santa Clara L. Rev. 929, 932-34 (2009); Jeffrey Rosen, Supreme Court Inc., N.Y. TIMES, Mar. 16, 2008, at MM38; David G. Savage, High Court Is Good for Business, L.A. Times, June 21, 2007, at A1; David G. Savage, Supreme Court Gives Firms a Stronger Hand, L.A. TimeS, June 25, 2011, at B1 ("The Supreme Court, which winds up its term Monday, has once again shown itself to be highly skeptical of large lawsuits against big business, regardless of whether the suits are intended to protect workers, consumers or the environment.").

Dean Chemerinsky in fact uses the practical impact of the Court's arbitration cases as an example of unreasonable, pro-business jurisprudence. See CHEMERINSKY, supra, at 227-31 (criticizing Circuit City Stores, Inc. v. Adams, 532 U.S. 105 (2001)); infra notes 320-28 and accompanying text (discussing Circuit City). As Dean Chemerinsky explained:

Several years ago, I bought a new computer from Dell. I was about to teach the material on arbitration to my first-year civil procedure class and decided to read the fine print that came with the agreement accompanying the computer. There was a clause that said that by buying the computer and by turning it on, I was agreeing that any dispute that I would have with Dell would go to arbitration and not to a jury trial. I sent a letter back to Dell saying, "I do not consent to this and by opening my letter you hereby consent that I can take you to court.” I am pleased to report that the computer worked fine and that I had no occasion for suing Dell.

[This example and another given earlier in the book] are illustrations of a national trend toward businesses demanding arbitration whenever possible and rejecting courts and jury trials....

Yale law professor Judith Resnik has documented... [that] businesses prefer arbitration ... [in part because there is] an institutionalized bias among arbiters in favor of repeat players in the system. ...

$\ldots$

... [T] [he Supreme Court has been pushing matters to arbitration when there is no such agreement between the parties.

Id. at 227-28 (discussing Circuit City as an example of a poorly reasoned arbitration decision unfair to workers). 
of head-over-heels, uncritically high regard or worship one associates with an immature "crush" or the placing of an object of affection on a figurative pedestal. But just as the infatuated might take a 180-degree turn against an object of affection, during the past two Terms the Court has taken such a turn, restricting the scope of arbitration in the face of objections by the economically powerful. ${ }^{10}$

Although the Court has been enamored of arbitration for three decades, the Court's love of arbitration took a distinctly tainted turn under the Roberts Court. Although the Burger and Rehnquist Courts worked a sea change in the law with their elevation of the status of mandatory binding arbitration, ${ }^{11}$ there were at least moments of caution and care as those Courts on occasion attempted-albeit highly imperfectly-to fairly apply the controlling statute, the Federal Arbitration Act. ${ }^{12}$ By contrast, the Roberts Court appears to have shed any fidelity to the rules of statutory construction, civil litigation, or judicial neutrality in promoting arbitration-except when arbitration is at odds with the interests of a more economically favored and powerful litigant. $^{13}$

Fifteen years ago, the Court's preference for arbitration was so pronounced that I described it as an "infatuation" in which the Court

10. See infra notes 355-74 and accompanying text (discussing Stolt-Nielsen); infra notes 386423, and accompanying text (discussing Concepcion).

11. Some scholars take the view that a standardized pre-dispute arbitration agreements contained in a contract of adhesion is not a "mandatory" binding arbitration agreement but simply a consensual contract. The view expressed in this Article is to the contrary. When courts enforce a standardized arbitration agreement that is part of a take-it-or-leave-it transaction, relatively hidden in the documentation of the transaction and not negotiated by the parties, the arbitration clause is not so much a contractual agreement as a required term of a transaction (e.g., borrowing funds, buying a cell phone) or relationship (e.g., employment). At least this is true so long as courts tend to give short shrift to the issue of whether the party adhering to the arbitration clause really "agreed" to the clause. See Jeffrey W. Stempel, Bootstrapping and Slouching Toward Gomorrah: Arbitral Infatuation and the Decline of Consent, 62 BROOK. L. REV. 1381, 1430 (1996) [hereinafter Stempel, Bootstrapping and Slouching] (noting judicial reluctance to seriously examine issues of consent to arbitration clauses); see also Jeffrey W. Stempel, Keeping Arbitrations from Becoming Kangaroo Courts, 8 NEV. L.J. 251, 261 (2007) (noting the degree to which arbitration is, as a practical matter, imposed by the contracting party with greater leverage); Jeffrey W. Stempel, Mandating Minimum Quality in Mass Arbitration, 76 U. CIN. L. REV. 383, 432-34 (2008) (noting the degree to which modern arbitration is often imposed en masse upon consumers or employees rather than being agreed to as part of contract negotiations); accord, Jean R. Sternlight, The Rise and Spread of Mandatory Arbitration as a Substitute for the Jury Trial, 38 U.S.F. L. REV. 17, 18 (2003) (making a similar point and referring to what this Article labels "new" or "mass" arbitration, in which standardized contracts issued in high volume routinely provide for arbitration).

12. See infra Part III.B-C.

13. See infra Part III.D. 
ignored important issues of consent in contracting. ${ }^{14}$ At that time, the Court's uncritical embrace of arbitration was only a dozen years old, a pre-teen crush of sorts. The Court's strongly pro-arbitration jurisprudence, which began in 1983 or 1984-depending on which arbitration critic you read, ${ }^{15}$ or perhaps even earlier ${ }^{16}$ - is now in its late twenties, a time when usually even the most romantic young person has grown up emotionally or at least been stripped of adolescent naivety.

But the Court's relentless veneration of arbitration continues unabated, as disturbingly reflected in Stolt-Nielsen S.A. v. AnimalFeeds International Corp. ${ }^{17}$ Rent-A-Center West, Inc. v. Jackson, ${ }^{18}$ and AT\&T Mobility LLC. v. Concepcion. ${ }^{19}$ In Stolt-Nielsen, the Court overturned an arbitration panel's decision to permit class action treatment of a matter based on the record of the dispute and the custom and practice of dispute resolution in this industry. ${ }^{20}$ In Rent-A-Center, the Court permitted the drafter of the arbitration agreement to eject the judiciary from the process of determining whether an arbitration agreement had in fact been madea decision at odds with the statutory language and the Court's prior precedent forbidding the parties to agree to an expanded judicial role in policing arbitration agreements and outcomes. ${ }^{21}$ In Concepcion, the Court upheld an arbitration clause restricting class actions notwithstanding California state contract law that deemed the term unconscionable as an impermissible limitation on consumer remedies. ${ }^{22}$

As discussed below, Concepcion is a particularly glaring display (by a bare 5-4 majority vote) of the Court's infatuation with arbitration overcoming what should have been its fidelity to the language,

14. See Stempel, Bootstrapping and Slouching, supra note 11, at 1412.

15. Compare Jean R. Sternlight, Panacea or Corporate Tool?: Debunking the Supreme Court's Preference for Binding Arbitration, 74 WASH. U. L.Q. 637, 660 (1996) (describing new proarbitration jurisprudence of the Court as beginning with Moses H. Cone Memorial Hospital $v$. Mercury Construction Corp., 460 U.S. 1 (1983)), with Paul D. Carrington \& Paul H. Haagen, Contract and Jurisdiction, 1996 S. CT. REV. 331, 880 (describing the Court's pro-arbitration era as beginning with Southland Corp. v. Keating, 465 U.S. 1 (1984)), and Jeffrey W. Stempel, Arbitration, Unconscionability, and Equilibrium: The Return of Unconscionability Analysis as a Counterweight to Arbitration Formalism, 19 OHIO ST. J. ON DISP. RES. 757, 776-79 (2004) (also seeing Southland as the inauguration of the Court's strong pro-arbitration jurisprudence).

16. See infra Part III.B-C (discussing pre-Moses H. Cone cases).

17. 130 S. Ct. 1758 (2010).

18. 130 S. Ct. 2772 (2010).

19. 131 S. Ct. 1740 (2011).

20. See infra notes 355-74 and accompanying text (discussing Stolt-Nielsen).

21. See infra notes 375-85 and accompanying text (discussing Rent-A-Center.).

22. See infra notes 386-423 and accompanying text (discussing Concepcion). 
legislative intent, and purpose of the Arbitration Act as well as inadequate appreciation of states' rights and the legal system's commitment to making the class action remedy available in appropriate cases. $^{23}$ Concepcion, like Stolt-Nielsen, is also a reflection of the Court's tainted love-an infatuation with arbitration when faced with issues of contract law, party consent, statutory construction, or public policy but a rejection of class action arbitration. Apparently, the Court's uncritical view of arbitration shatters when confronted with its hostility to class actions and its concern that powerful economic interests might lose some of their advantage from the leveling effects of the class device. ${ }^{24}$

Rather than solely picking on Concepcion as a particularly egregious example of the continued swoon of the Court (or at least five members of the Court) regarding arbitration ${ }^{25}$ or attacking many of the Court's modern arbitration decisions on their outcomes alone, this discussion will focus on the degree to which the Court's arbitration jurisprudence has been disturbing not merely because it is often wrong (at least in the eyes of many academic commentators and the dissenting Justices) but because it also has so frequently been at odds with the professed jurisprudential principles of the very Justices who have favored outcomes of enforced arbitrability.

When the arbitration decisions of the past three decades are examined under the majoritarian Justices' own widely accepted standards of jurisprudence and statutory construction, the decisions frequently fail the test of consistency and principle. In arbitration case after arbitration case, a majority of the Court has jettisoned the profession's alleged polestar jurisprudential principles in favor of compelling arbitration-

23. Id.

24. See Jeffrey W. Stempel, Class Actions and Limited Vision: Opportunities for Improvement Through a More Functional Approach to Class Treatment of Disputes, 83 WASH. U. L.Q. 1127, 1166 (2005) (noting the degree to which class treatment of issues tends to increase the leverage of less powerful litigants and observing that institutional or repeat-player litigants such as governments, businesses, or insurers tend to have this power in ordinary, non-class litigation); accord Bruce Hay \& David Rosenberg, "Sweetheart" and "Blackmail" Settlements in Class Actions: Reality and Remedy, 75 NotRE DAME L. REV. 1377, 1378-82 (2000) (noting the leveling effect of class treatment). For discussion of the degree to which repeat-player litigants have advantages over "oneshot" litigants (e.g., consumers, employees, or debtors), see Marc Galanter, Why the "Haves" Come Out Ahead: Speculations on the Limits of Legal Change, 9 LAW \& SOC'Y REV. 95 (1974) (the seminal article on this point); see also Joel B. Grossman, Herbert M. Kritzer \& Stewart Macaulay, Do the "Haves" Still Come Out Ahead?, 33 LAW \& Soc'Y REV. 803, 807-09 (1999) (finding continued vitality in Professor Galanter's typology and observation); Stempel, supra, at 1166 n.140.

25. See generally Catherine Fisk \& Erwin Chemerinsky, The Failing Faith in Class Actions: Wal-Mart v. Dukes and AT\&T Mobility v. Concepcion, 7 DUKE J. CONST. L. \& PUB. POL'y 73 (2011). 
unless it is the politically and economically stronger party that opposes arbitration, producing result-oriented adjudication that ranks among the worst examples in the Court's history. ${ }^{26}$

As a consequence, the Court has expanded the scope of the Federal Arbitration Act in ways that are inconsistent with the role of the judiciary as fair and principled stewards of the rule of law. Instead of consistent application of bedrock legal principles, the pro-arbitration Court decisions of the modern era have often been just that-pro-arbitration decisions fueled by infatuation with arbitration (or concerns about maintaining the distinction between arbitration and litigation) sprinkled with occasionally blatant preferences for the more powerful, rather than the type of reflective assessment one expects from the bench.

In "going gaga" over arbitration, the Court has diminished itself in the eyes of wide segments of the academy, the legal profession, and the public. $^{27}$ As Justice Jackson famously observed, the Court is not infallible but it is final. ${ }^{28}$ As a result, American law is for the moment "stuck" with the Court's arbitration decisions. But they have been controversial enough to fuel at least some non-trivial efforts at a legislative response, ${ }^{29}$ something that could become reality should the

26. There is, of course, always ample room to debate which Supreme Court decisions are the “worst." See, e.g., Symposium, Supreme Mistakes: Exploring the Most Maligned Decisions in Supreme Court History, 39 PEPPER. L. REV. 1-223 (2011) (legal scholars examine infamously bad Court decisions such as Dred Scott v. Sandford, 60 U.S. 393 (1857)); Carol J. Williams, Scholars Look at 'Supreme Mistakes', L.A. TIMES, Apr. 2, 2011, at AA3 (discussing Pepperdine Symposium); Symposium, The Worst Supreme Court Decision Ever?, 13 NEV. L.J. (forthcoming 2012) (legal scholars identify less notorious Supreme Court decisions as among the "worst" because of poor judicial craft, disingenuousness, or failure to appreciate the full context of the case).

27. Although there is substantial scholarship generally approving the Court's modern arbitration jurisprudence, the bulk of commentary on the Court's arbitration decisions of the past forty years has been quite critical. See, e.g., Stempel, supra note 15, at 758-62 (gathering critical commentary); see also David S. Schwartz, Enforcing Small Print to Protect Big Business; Employee and Consumer Rights Claims in an Age of Compelled Arbitration, 1997 WIS. L. REV. 33 (criticizing the Supreme Court's approval of pre-dispute arbitration clauses); Sternlight, supra note 15.

28. Brown v. Allen, 334 U.S. 443, 540 (Jackson, J., concurring) ("We are not final because we are infallible, but we are infallible only because we are final.”).

29. See, e.g., Arbitration Fairness Act of 2011, S. 987, H.R. 1873, 112th Cong. § 2 (2011); Arbitration Fairness Act of 2009, S. 931, H.R. 1020, 111th Cong. § 2 (2009); Arbitration Fairness Act of 2007, S. 1782, H.R. 3010, 110th Cong. § 2 (2007); see also Sarah Rudolph Cole, On Babies and Bathwater: The Arbitration Fairness Act and the Supreme Court's Recent Arbitration Jurisprudence, 48 Hous. L. REV. 457, 491-93 (2011) (discussing legislative efforts including the Arbitration Fairness Act of 2009 and the role of recent Supreme Court decisions in motivating its proponents); Stacy A. Hickox, Ensuring Enforceability and Fairness in the Arbitration of Employment Disputes, 16 WIDENER L. REV. 101, 102-03 (2010) (discussing the role of recent Supreme Court decisions in motivating legislative efforts like the Arbitration Fairness Act of 2009). 


\section{Democratic Party regain control of Congress. ${ }^{30}$ Further, many of the arbitration precedents were either analytically infirm or the result of a closely divided Court. ${ }^{31}$ They remain vulnerable to overruling depending on the luck of incumbent longevity and whether retirements or deaths take place during the term of a Republican or Democratic president. ${ }^{32}$}

30. See Mike Sacks, Arbitration Kickback: Supreme Court's Anti-Consumer Rulings Trigger Democratic Bills, HUFFINGTON POST, Feb. 10, 2012, http://www.huffingtonpost.com/2011/ 10/20/arbitration-supreme-court-decisions-democratic-bills_n_1022207.html (predicting that reform of the Arbitration Act will fail to pass in the current Congress because of Republican opposition). Although an unfortunately large proportion of legal scholarship proceeds as if judicial decisions are made in a political vacuum, there are clear ideological, political, and even partisan divisions over mandated arbitration and the enforcement of arbitration agreements, particularly "new" or "mass" arbitration agreements. See Stempel, Mandating, supra note 11, at 398-99 (discussing the "CounterRevolutionary Voices" opposing the trend toward "mass" arbitration). The strongest support for aggressive enforcement of the widespread standardized use of arbitration agreements has come from the business community, its counsel, political conservatives, and allied political interests. See Schwartz, supra note 27, at 78 (describing the Act as intended for the benefit of its business community proponents). Conversely, the Court's enthusiasm for promoting mandatory arbitration has been most resisted by consumer groups, employee groups, plaintiffs' counsel, and political liberals. See generally Sternlight, supra note 15, at 701 (arguing that "unregulated mandatory binding arbitration agreements can be detrimental to consumers, employees, and other little guys").

31. Several of the decisions treated by this article as most problematic were decided in 5-4 votes. See, e.g., AT\&T Mobility LLC v. Concepcion, 131 S. Ct. 1740, 1740 (2011); Rent-A-Ctr. West, Inc. v. Jackson, 130 S. Ct. 2772, 2772 (2010); Stolt-Nielsen, S.A. v. AnimalFeeds Int'l Corp., 130 S. Ct. 1758,1758 (2010).

32. Again, a little candor is in order notwithstanding the tendency of much legal scholarship to act as though the Justices' prior political affiliations are irrelevant to their judicial decision-making. In nearly all of the Court's reasonably "close" arbitration decisions of recent vintage-those decided by 5-4 or 6-3 votes-the Justices supporting enforced arbitration, but resisting class-wide arbitration, have been those appointed by Republican presidents while those resisting compelled arbitration or supporting class-wide arbitration were those appointed by Democratic presidents.

For example, the current Court's pro-arbitration/anti-class action stalwarts are Chief Justice John Roberts (appointed by Republican President George W. Bush) and Justices Samuel Alito (appointed by George W. Bush), Clarence Thomas (appointed by Republican President George H.W. Bush), Antonin Scalia (appointed by Republican President Ronald Reagan), and Anthony Kennedy (appointed by Reagan). The Justices resistant to imposed mass arbitration are Elena Kagan (appointed by Democratic President Barack Obama), Sonia Sotomayor (appointed by Obama), Stephen Breyer (appointed by Democratic President Bill Clinton), and Ruth Bader Ginsburg (appointed by Clinton).

Justice John Paul Stevens (appointed by Republican President Gerald R. Ford), who preceded Justice Kagan as a member of the Roberts Court, was perhaps the only real exception to this pattern, although one can make similar but weaker claims regarding Justice David Souter (appointed by George H.W. Bush). Justice Sandra Day O’Connor (appointed by Reagan), an important member of the Burger and Rehnquist Courts, also was less predictable in her arbitration jurisprudence, most prominently in opposing the Court's 1984 decision declaring that the Federal Arbitration Act constituted substantive federal law rather than merely a rule of procedure applicable in federal courts. See Southland Corp. v. Keating, 465 U.S. 1, 17 (1984) (O’Connor, J., dissenting); see also infra notes 169-214 and accompanying text (discussing Southland). To an extent, Justice Thomas sometimes runs counter to this typology. For example, during his first decade on the Court, he took the O’Connor position that Southland was wrongly decided. See infra notes 288, 314, 336, and 341 and accompanying text. But since the dawn of the Roberts Court in 2004, Justice Thomas has 
almost always aligned with the pro-arbitration interests or the pro-powerful business forces. See infra Part III.C-D (discussing arbitration cases of the late Rehnquist Court and the Roberts Court). 
Although many questions of law are sufficiently political to engender opposition and thoughts of turning the tables in the future, the arbitration precedents are a lightning rod for criticism as well as possible legislative reform. These are particularly bad Court decisions in part because of their outcomes (e.g., requiring employees to arbitrate, shunting disputes to potentially unfair forums, or preventing class action treatment for the very types of cases for which they were designed). The Court's arbitration decisions are perhaps most condemnable because they reflect Court majorities in which the prevailing Justices were so attracted to arbitration (consciously or subconsciously) — or rather a particular type of arbitration that was distinctly more constrained than litigation-on grounds of personal preference that they acted in derogation of mainstream legal analysis as well as their own asserted long-time jurisprudence of adjudication and correct construction of positive law.

\section{THE LEGAL RULES OF THE JUDICIAL ROAD AND THE JURISPRUDENCE OF THE JUSTICES}

The term "rule of law" has now been so overused as to become something of a cliché. Both lawyers and laypersons increasingly seem to see judging as an exercise in policy preferences, a perception fed by recent battles over the disqualification practices of the Supreme Court as Democrats and Republicans squared off in efforts to keep Justices Elena Kagan and Clarence Thomas from participating in the review of the constitutionality of the Obama administration's health care legislation enacted in 2010. ${ }^{33}$

33. See Tony Mauro, Kagan, Thomas Appear Unlikely to Recuse in Health Care Reform Case, 246 N.Y. L.J. 6, Nov. 17, 2011, available at http://www.newyorklawjournal.com/PubArticle NY.jsp?id=1202532665408\&slreturn=1 (describing calls for Justice Kagan's recusal based on her prior job as Solicitor General at the time when the Obama administration was considering legal strategy in defending the Affordable Health Care Act of 2009 and for Justice Thomas's recusal based on his wife's employment as a conservative activist opposing the law).

The conventional wisdom is that under prevailing rules neither Justice must recuse. See Michael Mukasey, The ObamaCare Recusal Nonsense, WALl ST. J., Dec. 5, 2011, at A17 (former federal trial judge and attorney general finding no merit to recusal arguments); Dahlia Lithwick, Musing About Recusing, SLATE (Nov. 16, 2011, 7:00 PM), http://www.slate.com/articles/ news_and_politics/jurisprudence/2011/11/should_elena_kagan_recuse_herself_from_the_obamacare _case_of_course_not_html (prominent liberal legal journalist expressing a similar view). And as a practical matter, both Justices decided against recusing themselves from the case. How Health Care Case Will Unfold Before the Court, NPR (Mar. 24, 2012, 7:12 AM), http://www.npr.org/ templates/story/story.php?storyId=149277795.

But there was substantial support for the view that recusal would have been apt. See, e.g., Ronald D. Rotunda, Kagan Must Recuse from Obamacare Case, WASH. TIMES, Dec. 16, 2011, at B1 
Despite increasingly obvious partisan invocation of the law, a substantial portion of the bench and the legal profession in general, continues to agree about basic aspects of jurisprudence. Even if judges cannot always agree about the precise contours of "the law" by which we will be ruled, they usually can agree on the rules of the legal process and, in particular, approaches to construing statutes, assessing constitutional concerns, adhering to stare decisis, and applying precedent. ${ }^{34}$ The legal system embraces a reasonably concrete set of basic ground rules for statutory construction. ${ }^{35}$ The Supreme Court similarly embraces-or at least claims to embrace-these mainstream judicial approaches. ${ }^{36}$

(noted conservative law professor finding grounds for Kagan recusal); Deborah Rhode, Ethical Oversight for the Justices, NAT'L L.J., Mar. 14, 2011, available at http://law.com/jsp/ nlj/PubArticleNLJ.jsp?id=1202485716021 (noted liberal law professor finding Justice Thomas's situation troubling and noting other instances of excessive coziness between conservative Justices and powerful business or government figures with matters before the Court, most infamously Justice Scalia's duck hunting trip with former Vice President Dick Cheney, then a defendant in a case challenging his energy task force's confidential meetings with industry lobbyists).

The situation raised enough discomfort to spawn two lawsuits directed toward developing evidence in support of recusal—one by a liberal group, one by a conservative group—and proposed legislation broadening the grounds for disqualification of the Justices. See Supreme Court Transparency and Disclosure Act of 2011, H.R. 862, 112th Cong. § 2 (2011) (proposing application of the Code of Conduct to Supreme Court Justices); Media Research Ctr. v. U.S. Dep't of Justice, Nos. 10-2013 (ESH), 11-0426 (ESH), 2011 WL 4852224, at *13 (D.D.C. Oct. 13, 2011) (granting summary judgment on a motion by the Justice Department in a consolidated action under Freedom of Information Act).

34. See, e.g., Eva H. Hanks, Michael E. Herz \& Steven S. NEmerson, Elements of LAW 163-206, 253-296, 329-340 (2d ed. 2010) (discussing stare decisis and precedent, as well as theories and sources of statutory interpretation and canons of construction, noting that at least "a moderately strong consensus... holds among most contemporary judges" regarding theories of statutory interpretation); see also Michael A. Berch, ReBeCCA White BerCH \& RALPH S. Spritzer, Introduction to Legal Method and Process: Cases AND Materials 34-35, 40 52, 57-69, 379-86, 436-46, 476-77 (3d ed. 2002) (discussing the concept of stare decisis and role of precedent in judicial decisions, with a focus on jurists' views of the judicial process and function, with additional discussion of the interpretation of statutes and constitutional limitations on the power of federal courts to hear cases). See generally Charles R. CALleros, LegAL METHOD AND WRITING 53-67 (6th ed. 2011) (discussing the role of precedent and the doctrine of stare decisis in the court system).

35. See William N. Eskridge, JR. et al., Cases and Materials on Legislation: Statutes AND the CREATION OF Public Policy chs. 7-8 (4th ed. 2007) (describing mainstream approaches to statutory construction based on a law's text, legislative background, purpose, and function); see also id. at 847-1100 (discussing widely accepted rules, presumptions, and canons of statutory construction as well as accepted extrinsic sources for statutory interpretation, including legislative background).

36. See, e.g., Dolan v. U.S. Postal Serv., 546 U.S. 481, 486 (2006) (stating that the interpretation of a word or phrase in a statute "depends upon reading the whole statutory text, considering the purpose and context of the statute, and consulting any precedents or authorities that inform the analysis"); Dodd v. United States, 545 U.S. 353, 357 (2005) (holding that the text of a statute resolved a dispute over interpretation, remarking that the Court "must presume that [the] legislature says in a statute what it means and means in a statute what it says there" (citation omitted) 
Justices in the majority in most of the arbitration cases over the past thirty years are particularly likely to style themselves as mainstream and resist allegations of judicial activism, ${ }^{37}$ although their application of mainstream jurisprudence often has a conservative slant. ${ }^{38}$

(internal quotation marks omitted)); Norfolk \& W. Ry. Co. v. Am. Train Dispatchers Ass'n, 499 U.S. 117, 128 (1991) ("As always, we begin with the language of the statute and ask whether Congress has spoken on the subject before us. 'If the intent of Congress is clear, that is the end of the matter; for the court ... must give effect to the unambiguously expressed intent of Congress."” (quoting Chevron, U.S.A., Inc. v. Natural Res. Def. Council, Inc., 467 U.S. 837, 842-43 (1984))); see also ANTONIn SCALIA, A MATTER OF INTERPRETATION: FEDERAL COURTS AND THE LAW 14-37 (1997) (expressing support for strict textual reading of law, following established doctrine, and deferring to original understanding of laws); Stephen Breyer, Judicial Review: A Practicing Judge's Perspective, 78 TEX. L. REV. 761, 766 (2000) (expressing a less text-centered view that gives more weight to legislative background and functional operation of statutes but a view not widely disparate from that of the considerably more conservative Justice Scalia); Stephen Breyer, On the Uses of Legislative History in Interpreting Statutes, 65 S. CAL. L. REV. 845, 847 (1992) (arguing for the use of legislative history when the statute's text is ambiguous); Antonin Scalia, The Rule of Law as a Law of Rules, 56 U. CHI. L. REV. 1175, 1184-85 (1989) (expressing support for strict textual reading, following established doctrine, and deferring to original understanding of laws). See generally Richard A. POSNER, How Judges THINK (2008) (expressing a legal realist view of the judicial process that includes a chapter entitled "The Supreme Court Is a Political Court" but nonetheless also observing the widespread judicial embrace of mainstream legal principles and the strong tendency of jurists to wish to be perceived as fair-minded, mainstream, and not excessively political, partisan, or result-oriented).

37. See generally Timothy L. HALl, Supreme COURT Justices: A BiographicAL DICTIONARY 358-61, 380-432 (2001) (discussing the backgrounds and the professional and public view of the mainstream judicial approaches of Justices William Brennan, Potter Stewart, Byron R. White, Thurgood Marshall, Warren E. Burger, Harry Blackmun, Lewis Powell, William Rehnquist, John Paul Stevens, Sandra Day O’Connor, Antonin Scalia, Anthony Kennedy, David Souter, Clarence Thomas, Ruth Bader Ginsburg, and Stephen Breyer, all Justices participating in the Court's modern arbitration decisions during the period from 1980 to the present); DAVID G. SAVAGE, II GUIDE TO THE U.S. SUPREME COURT 1049-61, 1160-66 (5th ed. 2010) (discussing Court membership and fitting Justices into legal establishment even if they are otherwise demographically diverse and providing brief biographies of Justices involved in Court's modern arbitration decisions from Justice William Brennan to Justice Sonia Sotomayor).

This Article is not naively suggesting that there are no significant jurisprudential differences between the Justices. On the contrary, some are distinctly more liberal or more conservative, more formalist or functionalist, more textual or more contextual than others. See generally HENRY J. Abraham, Justices, Presidents, and Senators: A History of U.S. Supreme Court APPOINTMENTS FROM WASHINGTON TO BUSH II (5th ed. 2008) (providing a particularly candid and realistic history of the degree to which ideological, jurisprudential, political, and even partisan factors played a role in the appointment and confirmation process). But notwithstanding the very real differences between the Justices, a review of their backgrounds demonstrates that all qualify as "mainstream" judicial actors that purport to agree on basic premises of the legal process and do not espouse "impermissible" views that would have threatened or precluded nomination and confirmation.

38. In particular Justices such as Warren Burger, Sandra Day O’Connor, Anthony Kennedy, David Souter, John Roberts, Antonin Scalia, Clarence Thomas, and Samuel Alito are generally characterized as judicial conservatives, particularly the latter four. See ABRAHAM, supra note 37, at 233-324 (discussing the judicial conservatism of these Justices as it related to their appointment); HALL, supra note 37, at 384-87, 404-23 (describing the political leanings of Justices Burger, 
This judicial center of gravity seems particularly well established in matters of statutory interpretation. Although the Court's major arbitration cases present a range of legal questions, all are statutory construction cases focusing on the proper application of the Federal Arbitration Act-sometimes alone, sometimes in combination or arguable conflict with other statutes. Regarding statutory construction, the Supreme Court, during the same period that it has longingly embraced arbitration, has also professed fidelity to a statutory construction regime emphasizing the following interpretative tools.

\section{A. Statutory Text}

Mainstream legal thought places substantial emphasis on statutory text, and the Court has repeatedly used a statute's text as the starting point for assessing a statute such as the Arbitration Act. ${ }^{39}$ Justice Antonin Scalia is famous for his heavily textualist brand of statutory construction that looks almost exclusively at the text of the statute and eschews examination of the legislative history of the law or its overall purpose. $^{40}$ But even relative non-textualists such as Justice Stephen

O’Connor, Scalia, Kennedy, Souter, and Thomas); THOMAs M. KecK, THE Most Activist SUPREMe COURT IN History: THE ROAD TO MODERN JUdiCial CONSERVATISM 107-96 (2004) (describing the rise of the conservative wing of the Court starting with the end of the Warren era). See generally BERNARD SCHWARTZ, A HISTORY OF THE SUPREME COURT 311-36, 362-77 (1993) (describing the historical development of the Burger and Rehnquist Courts); THE UNITED STATES Supreme Court: THE PuRsuit of Justice 463-64, 492, 504-05, 514, 512-13, 521-22 (Christopher Tomlins ed., 2005). But none of these Justices are described as so conservative as to fall outside the judicial mainstream or be accused of espousing views inconsistent with the basic legal canon. But see CHEMERINSKY, supra note 9 (suggesting that in practice and application, the current conservative Justices are rendering decisions inconsistent with the Constitution).

39. See ESKRIDGE ET AL., supra note 35, at 765-66 (noting that Judge Frank Easterbrook insists that courts have no authority even to apply a statute to a problem unless the statute's language clearly targets that problem); see also Circuit City Stores, Inc. v. Adams, 532 U.S. 105, 109 (2001) (relying on the "plain meaning" of the Federal Arbitration Act's clause that excludes from coverage "contracts of employment of seamen, railroad employees, or any other class of workers engaged in foreign or interstate commerce," and holding that the Act exempts only contracts of employment of transportation workers, not all employment contracts (quoting 9 U.S.C. § 1 (2008))); Gilmer v. Interstate/Johnson Lane Corp., 500 U.S. 20, 25 n.2 (1991) (following the "plain language of the FAA" in holding that the Act's exclusionary clause did not apply to the employee's arbitration agreement, which was contained in a securities registration application and not an employment contract).

40. See ESKRIDGE, ET AL., supra note 35, at 765 (noting that Justice Scalia delivered a series of speeches urging courts to abandon virtually any reference to legislative history); William $\mathrm{N}$. Eskridge, Jr., The New Textualism, 37 UCLA L. REV. 621, 623 (1990) (describing Scalia’s refusal to look at legislative history); Jonathan T. Molot, The Rise and Fall of Textualism, 106 CoLUM. L. REV. 1, 32-33 (2006) (noting one finds more textual rhetoric in the opinions of Justices Scalia and Thomas); Nicholas S. Zeppos, Justice Scalia's Textualism: The "New” New Legal Process, 12 
Breyer, a comparative fan of legislative history and deferring to agency constructions of a statute, ${ }^{41}$ agree that the text of the law is the most important consideration and the place where statutory construction must begin. $^{42}$ Chief Justice Roberts-and Chief Justices Rehnquist and Burger before him-and the other Justices of the current Court all agree on the importance of text, with Justices Kennedy, Thomas, and Alito appearing closer to Justice Scalia's more textual orientation. Other Justices serving during the modern pro-arbitration era of the Court, including Justices Blackmun, Stevens, O’Connor, and Souter, also reflected the legal profession's general preference for the primacy of text in statutory construction, even if the primacy is at times a "soft" one. Overall, the Court as a whole has historically tended to operate in a pragmatic, largely centrist manner without undue emphasis on any particular method of statutory interpretation. ${ }^{43}$

\section{B. Legislative Intent}

All members of the Court during the modern pro-arbitration era, except Justice Scalia, acknowledge that the drafting history and

CARDOZo L. REV. 1597, 1598 (1991) (noting that Justice Scalia has urged the abandonment of the Court's traditional use of legislative history); see also WILLIAM D. POPKIN, MATERIALS ON Legislation, Political Language And the Political Process ch. 5 (5th ed. 2009) (providing a general overview of problems with the overly textualist view and noting leavening doctrines such as the whole act rule and the canon against overly literal constructions that leads to an absurd result).

41. See Stephen Breyer, On the Uses of Legislative History in Interpreting Statutes, 65 S. CaL. L. REV. 845 (1992) (defending the legitimacy of legislative intent as an interpretative tool); see also ESKRIDGE ET AL., supra note 35, at 955-56, 971-73, 990 n.j (noting acceptance of legislative background and other extrinsic information as tools of statutory construction and collecting substantial academic commentary to support both Justice Breyer's and Justice Scalia's view of the role of legislative history).

42. See, e.g., Minn. STAT. AnN. § 645.16 (West 1947) (codifying the view that legislative intent "controls" judicial construction of statutory meaning) ("The object of all interpretation and construction of laws is to ascertain and effectuate the intention of the legislature."); United States v. Tinklenberg, 131 S. Ct. 2007, 2012 (2011); Kasten v. Saint-Gobain Performance Plastics Corp., 131 S. Ct. 1325, 1331 (2011) (stating that "[w]e begin with the text of the statute" in a case involving interpretation of a Fair Labor Standards Act provision); POPKIN, supra note 40, at chs. 2-5 (noting that for most of legal history legislative intent or purpose was seen as the touchstone of statutory construction and even more salient than statutory text but that text has attained more prominence in modern statutory construction theory).

43. See, e.g., William N. Eskridge, Jr. \& Philip P. Frickey, Foreword: Law as Equilibrium, 108 HARV. L. REV. 26, 57 (1994) (observing that the Court is unlikely to adhere to any single foundation for interpreting statutes); William N. Eskridge, Jr. \& Philip Frickey, Statutory Interpretation as Practical Reasoning, 42 STAN. L. REV. 321, 322 (1990) (suggesting that the Court considers a broad range of textual, historical, and evolutive evidence when it interprets statutes) [hereinafter Eskridge \& Frickey, Statutory Interpretation]. 
legislative intent of a statute are relevant to determining its meaning and application in particular contexts. ${ }^{44}$ The Justices vary in the degree to which they will end their inquiry if the text appears to direct a result. ${ }^{45}$ Some appear to see legislative history as inappropriate unless the statutory text is ambiguous, while others appear willing to consult legislative history as a check on their reading of the text. A few, on occasion, even suggest that sufficiently clear legislative intent may be invoked to determine if seemingly clear statutory language is a drafting error. $^{46}$ The Justices also frequently differ, of course, as to whether particular language is ambiguous. ${ }^{47}$

44. See, e.g., FDA v. Brown \& Williamson Tobacco Co., 529 U.S. 120, 146-161 (2000) (utilizing legislative in the majority opinion by Justice O'Connor, which Justices Scalia and Thomas joined); Blanchard v. Bergeron, 489 U.S. 87, 91 (1989) (invoking legislative history in Justice White's majority opinion); Kosak v. United States, 465 U.S. 848, 855-61, 862-69 (1984) (using legislative history in Justice Marshall's); id. at 862-69 (Stevens, J., dissenting) (taking a textualist approach); Bob Jones Univ. v. United States, 461 U.S. 574, 599-602 (1983) (considering legislative history in Chief Justice Burger's opinion for the Court); Leo Sheep Co. v. United States, 440 U.S. 668, 669-70 (1979) (relying heavily on legislative background and perceived intent and purpose of Congress in Justice Rehnquist's opinion); see also James J. Brudney \& Corey Ditslear, Liberal Justices' Reliance on Legislative History: Principle, Strategy, and the Scalia Effect, 29 BERKELEY J. EMP. \& LAB. L. 117, 169-70 (2008) (finding that both liberal and conservative Justices make frequent resort to legislative history); Patricia M. Wald, Some Observations on the Use of Legislative History in the 1981 Supreme Court Term, 68 IowA L. REV. 195, 214 (1983) (noting widespread acceptance of legislative history as an interpretative tool but contending that the Court has not been following "consistent and uniform rules for statutory construction and use of legislative materials"). But see ESKRIDGE ET AL., supra note 35, at 987-90 (noting Justice Scalia's opposition to the use of legislative history, specifically committee reports).

45. See, e.g., Green v. Bock Laundry Mach. Co., 490 U.S. 504, 507, 527, 530 (1989) (providing three different approaches to the use of legislative history in the majority, concurring, and dissenting opinions).

46. See, e.g., Christian E. MAMmen, Using Legislative History in AMERICAN StATUTORY INTERPRETATION 10-11 (2002) (describing various "interpretive agendas" of Supreme Court Justices); Abner S. Greene, The Missing Step of Textualism, 74 FordHAM L. REV. 1913, 1916 (2006) (describing the contrasting views of "purposivists" and "textualists" toward legislative history); Anita S. Krishnakumar, Statutory Interpretation in the Roberts Court's First Era: An Empirical and Doctrinal Analysis, 62 HASTINGS L.J. 221, 241-42, 50-58 (2011) (describing the Roberts Court's perspectives on, and use of, interpretive tools, such as legislative history and legislative intent).

47. Compare Sossamon v. Texas, 131 S. Ct. 1651, 1659-68 (2011) (concluding that no statute expressly and unequivocally includes a waiver of sovereign immunity to private suits for money damages under the Religious Land Use and Institutionalized Persons Act (RLUIPA)), with id. at 1664-68 (Sotomayor, J., dissenting) (stating the majority's conclusion cannot be reconciled with the fact that the availability of such relief is evident in light of RLUIPA's plain terms). Other examples exist. Compare Negusie v. Holder, 555 U.S. 511, 517 (2009) (concluding the Immigration and Nationality Act has an ambiguity), with id. at 550 (Thomas, J., dissenting) (noting a statute cannot be deemed ambiguous until the court exhausts the traditional tools of statutory construction). 


\section{Legislative Purpose}

Legislative intent connotes a specific intent of the legislature to achieve a particular result or that courts apply statutory language in a specific way in situations envisioned by the drafters. ${ }^{48}$ Legislative purpose connotes more general goals of the statute. ${ }^{49}$ For example, where the legislative history reflects congressional consensus that particular legal precedents be overturned, this is a matter of legislative intent. The Pregnancy Discrimination Act, ${ }^{50}$ for example, was designed specifically to overrule the Court's 1976 General Electric Co. v. Gilbert decision by deeming pregnancy discrimination a violation of Title VII, a reversal of the Court's finding that pregnancy discrimination by an employer did not violate Title VII because only women get pregnant. ${ }^{51}$

Where, by contrast, the legislative history reflects a more general congressional desire to achieve certain results, or to prevent or discourage undesirable results, this is a matter of legislative purpose. For example, the Private Securities Litigation Reform Act of $1995^{52}$ (PSLRA) was designed to make it more difficult to bring securities violation lawsuits on the basis of a hunch and, therefore, required more particularized pleading. The statute did not, however, clearly state whether the specified pleading standards found in case law applying Federal Rule of Civil Procedure 9(b) were adequate. ${ }^{53}$ Based on the legislative purpose of the law and its enactment, notwithstanding the existence of Rule 9(b), a judge might view the legislative purpose as requiring more particularized pleading than found under the Rule in cases subject to the PSLRA. ${ }^{54}$ Conversely, a judge might find

48. See POPKIN, supra note 40, at 251-56 (noting the distinction between legislative intent as something specifically sought by an enacting legislature and legislative purpose as the more generalized goals of legislation).

49. Id.

50. Pub. L. No. 95-555, 92 Stat. 2076 (codified as amended in scattered sections of 42 U.S.C.).

51. Gen. Elec. Co. v. Gilbert, 429 U.S. 125, 134, 145-46 (1976), superseded by statute, Civil Rights Act of 1964, Pub. L. No. 95-555, 92 Stat. 2076; see also AT\&T Corp. v. Hulteen, 129 S. Ct. 1962, 1967, 701 (2009) (noting that current statutory provision superseded Gilbert).

52. See 15 U.S.C. § 78u-4(b) (2006) (codification of pleading standards of Private Securities Litigation Reform Act (PSLRA) of 1995).

53. See Marc I. Steinberg \& Diego E. Gomez-Cornejo, Blurring the Lines Between Pleading Doctrines: The Enhanced Rule 8(a)(2) Plausibility Pleading Standard Converges with the Heightened Fraud Pleading Standards Under Rule 9(b) and the PSLRA, 30 REV. LITIG. 1, 16-25 (2010).

54. See, e.g., Hill v. Gozani, 638 F.3d 40, 55 (1st Cir. 2011) (noting that the PSLRA goes further than Fed. R. Civ. P. 9(b) with regard to the scienter element and requires that the pleading "state with particularity facts giving rise to a strong inference that the defendant acted with the 
congressional silence on the issue an indication that Congress, despite its general concern over weak securities claims filed on a hunch, simply wanted something more than mere notice pleading and wider application of cases taking a strong view of Rule 9(b). ${ }^{55}$

Another example is provided by the Sherman ${ }^{56}$ and Clayton $^{57}$ Antitrust Acts, which were both designed to fight monopolization and to forbid contracts, combinations, and conspiracies in restraint of tradebut Congress was relatively vague about how that should be done. Although there is some legislative history suggesting that the laws were designed to prevent specific behemoths such as the Sugar Trust or the domination of the oil industry by John D. Rockefeller's Standard Oil Company, the statutes are, in the main, laws expressing general purposive guidelines. ${ }^{58}$ As a result, the courts have tended to apply "rules of reason" rather than per se rules in many cases challenging alleged anti-competitive conduct. ${ }^{59}$ Judge Posner has characterized the

required state of mind” (quoting 15 U.S.C. § 78u-4(b)(2)(A))); In re Alpharma Inc. Sec. Litig., 372 F.3d 137, 148 (3d Cir. 2004) (stating "to the extent that Rule 9(b)'s allowance of general pleading with respect to mental state conflicts with the PSLRA's requirement that plaintiffs 'state with particularity facts giving rise to a strong inference that the defendant acted with the required state of mind,' the PSLRA supersedes Rule 9(b) as it relates to Rule 10b-5 actions" (citation omitted) (quoting 15 U.S.C. § 78u-4(b)(2)(A))).

55. Justice Stevens was perhaps the best known proponent of what is sometimes called the "dog didn’t bark” approach to statutory construction. See, e.g., Chisom v. Roemer, 501 U.S. 380, 389 ("Congress would not have authorized vote dilution claims in judicial elections without making an express, unambiguous statement to that effect.”). Under this view, congressional silence can be regarded as meaningful and frequently is invoked to suggest that a newly enacted statute was not designed to overturn an established practice touching on the area of statutory concern. If Congress wanted to make a change, then it logically would have indicated as much the face of the statute or in the legislative history. That Congress did not speak implies it intended no such change. See ESKRIDGE ET AL., supra note 35, at 1035.

The metaphor is taken from the Sherlock Holmes story involving the theft of a prize racehorse at night from a stable in which the family dog did not bark during the burglary. Chisom, 501 U.S. at 396 n.23. Holmes correctly discerns that the thief must have been "someone whom the dog knew well," such that the animal was not alarmed enough to bark. Id.; see also ARTHUR CONAN DOYLE, Silver Blaze, in THE COMPLETE SHERlOCK Holmes 415 (Barnes \& Noble Classics ed., 2003).

56. See 15 U.S.C. §§ $1-7$ (2006).

57. See id. §§12-27.

58. See Robert H. Bork, Legislative Intent and the Policy of the Sherman Act, 9 J.L. \& Econ. 7, $10-11$ (1966).

59. See Herbert Hovenkamp, Federal Antitrust Policy: The LaW of Competition AND ITS PRACTICE $\S 6.4$ (4th ed. 2011) ("In antitrust litigation most practices are considered to be analyzed under a rule of reason. A per se rule is generally appropriate only after judges have had long experience with a certain practice, and have concluded that the practice produces many pernicious results and almost no beneficial ones.”); RICHARD A. POSNER, ANTITRUST LAW 39-40 (2d ed. 2001) (distinguishing "Rule of Reason" from per se rules in the antitrust context); 1 JULIAN O. VON KALINOWSKI ET AL., ANTITRUST LAWS AND TRADE REGULATION § 8.01(2) (b) (2d ed. 1999) ("Consequently, the common law courts sustained particular restrictions provided that they were 
Sherman Act as something of a common law statute, one that seems to invite judicial application because of the absence of specific directives in the law's text or legislative history. ${ }^{60}$

In construing the antitrust laws, the Court has used legislative purpose to trump the actual text of the law. For example, if the Sherman Act were read literally and applied to "every" contract restraining trade, ${ }^{61}$ franchises and licenses would be forbidden, because this is both the literal language of the statute and because all contracts by definition constrain the contracting parties to at least some degree, in that, as a result of the contract, they are obligated to perform or pay damages. ${ }^{62}$ This view can also be considered akin to the "absurd result" canon of statutory construction, a principle positing that statutory text will not be applied so literally as to render an absurd result. ${ }^{63}$

both reasonable and ancillary to the main transaction. Of particular importance is the fact that the 'rule of reason,' a method by which the legality of restraints are analyzed, is derived directly from these exceptions for reasonable and ancillary restraints.”); see also 15 U.S.C. § 9.02(3)(b) (“A close examination of the substantive provisions of the Sherman Act reveals that the Act does not make specific methods of business conduct or particular types of business arrangement unlawful. Congress chose, instead, to adopt a statute that, by the very generality of its language, would interdict any contract, combination, or conspiracy that restrained trade as well as monopolies. Because the Sherman Act is couched in such broad terms, the courts have been able to adapt it to the changing methods of commercial production and distribution since its enactment.”).

60. See Richard A. Posner, Legal Formalism, Legal Realism, and the Interpretation of Statutes and the Constitution, 37 CASE W. RES. L. REV. 179, 212 (1986) ("The Sherman Act is a standard instance of a statute that is poorly thought through, that is delivered to the courts in a severely incomplete state, that begs - though it doesn't actually ask - the courts to do what they can to make it reasonable."); Richard A. Posner, Statutory Interpretation-In the Classroom and in the Courtroom, 50 U. CHI. L. REV. 800, 818 (1983) ("Sometimes a statute will state whether it is to be broadly or narrowly construed; more often the structure and language of the statute will supply a clue. If the legislature enacts into statute law a common law concept, as Congress did when it forbade agreements in 'restraint of trade' in the Sherman Act, that is a clue that the courts are to interpret the statute with the freedom with which they would construe and apply a common law principle....”); accord HovenKAMP, supra note 59, § 2.1b ("Federal courts have always interpreted the antitrust statutes in a common law fashion, and the result is a substantial divergence between statutory language and judicial decision.”).

61. The Sherman Act states that " $[e]$ very contract, combination ... or conspiracy, in restraint of trade” is illegal. See 15 U.S.C. § 1 (emphasis added).

62. See David G. Epstein, Bruce A. Markell \& Laurence Ponoroff, MaKing AND Doing DEALS: CONTRACTS IN CONTEXT 1-3 (2d ed. 2006) (observing that contract law exists to satisfy the basic impulse that the reasonable expectations excited by a promise are entitled to recompense in a court of law).

63. See United States v. Wilson, 503 U.S. 329, 334 (1992) (applying the absurd result exception to the general rule of applying the "plain" textual meaning of statute); Green v. Bock Laundry Mach. Co., 490 U.S. 504, 509-11 (1989) (noting that a "literal reading would compel an odd result in a case like this"). 


\section{The Hierarchy of Legislative History}

Not all legislative history is created equal, but jurists tend to agree on the relative authority and persuasiveness of different forms of legislative history. In general, there is a preference, in roughly the following order for: committee reports, ${ }^{64}$ statements by the chief authors of the legislation, hearing testimony and congressional reaction, floor statements, and contemporary accounts of enactment of the legislation. ${ }^{65}$

\section{E. Canons of Construction}

Canons of statutory construction are general rules for interpreting the laws and are derived from common understandings of drafting conventions, legislative processes, public policy, or jurisprudence. ${ }^{66}$ Although varying in their affection for particular canons, all of the Justices appear to find them potentially useful in particular situations. Among the more commonly invoked canons are those of textual construction such as: ${ }^{67}$

- the plain meaning rule, which requires adherence to the clear linguistic meaning of statutory text unless this would bring about an absurd result or there is evidence that the text is in error in departing from the specific intent of the legislature; ${ }^{68}$

64. See Jorge L. Carro \& Andrew R. Brann, The U.S. Supreme Court and the Use of Legislative Histories: A Statistical Analysis, 22 JURIMETRICS J. 294, 304 (1982) (over a forty-year period, more than forty-five percent of the Court's citations to legislative history were to committee reports); see, e.g., Hishon v. King \& Spalding, 467 U.S. 69, 75, n.7 (1984) (relying on a Senate report regarding a civil rights bill that was not enacted but that included similarities to the Civil Rights Act of 1964).

65. See ESKRIDGE ET AL., supra note 35, at 981, 1029 (observing that compared to committee reports, statements made during committee hearings and floor debates have traditionally received less weight); POPKIN, supra note 40, at 6, 9-11; see also OtTO J. HETZEL ET AL., LEGISLATIVE LAW AND STATUTORy INTERPRETATION: CASES AND MATERIAls 589-90 (3d ed. 2001) (providing an extensive list of twenty different forms of legislative background information that courts may use).

66. See generally, HETZEL ET AL., supra note 65, at 705-65 (discussing judicially created canons).

67. See ESKRIDGE ET AL., supra note 35, app. B (presenting an exhaustive review of the canons).

68. See id.; see, e.g., Barnhart v. Thomas, 540 U.S. 20, 26-29 (2003) (noting that "when a statute is 'silent or ambiguous' we must defer to a reasonable construction”). 
- expressio unius exclusio alterius, meaning the expression of one thing suggests the exclusion of things not included in the list or catalog; ${ }^{69}$

- noscitur a sociis, which requires a general term to be construed in a manner consistent with similar specific terms in a statute ${ }^{70}$

- ejusdem generis, providing that general terms should be construed to reflect the class of objects shown in exemplary or specific terms used in the statute; ${ }^{71}$

- preference for ordinary meaning rather than technical or specialist meaning (unless there is strong legislative history indicating congressional preference for the specialized meaning); ${ }^{72}$

- continued use of the settled meaning of terms previously defined in adjudication; ${ }^{73}$

- use of dictionary definitions (unless there is evidence to suggest this definition was not intended by Congress); ${ }^{74}$

- deference to experts, such as administrative agencies, regarding the meaning of a term; ${ }^{75}$ and

69. See ESKRIDGE ET AL., supra note 35, app. B, at 19.

70. See id. app. B, at 20; see, e.g., Gustafson v. Alloyd Co., 513 U.S. 561, 575 (1995) (noting that "[t]he constructional problem is resolved by the ... principle ... that a word is known by the company it keeps").

71. See ESKRIDGe ET AL., supra note 35, app. B, at 20; see, e.g., Circuit City Stores, Inc. v. Adams, 532 U.S. 105, 106 (2001) (applying ejusdem generis to the terms "seamen" and "railroad employees"); see also infra notes 320-28 and accompanying text (discussing Circuit City).

72. See ESKRIDGE ET AL., supra note 35, app. B, at 20; see, e.g., Will v. Mich. Dep’t of State Police, 491 U.S. 58, 65 (1989) (citing the preference for ordinary meaning as an "ordinary rule of statutory construction").

73. See ESKRIDGE ET AL., supra note 35, app. B, at 20; see, e.g., Stewart v. Dutra Constr. Co., 543 U.S. 481, 487 (2005) (presuming that Congress intended the word "seaman" to have the same meaning as under established maritime law).

74. See ESKRIDGE ET AL., supra note 35, app. B, at 20; see, e.g., Pittston Coal Group v. Sebben, 488 U.S. 105, 113 (1988) (citing the Webster's Dictionary definition of “criteria”).

75. See ESkRIDGe ET AL., supra note 35, app. B, at 20; see e.g., Zuni Pub. Sch. Dist. No. 89 v. Dep't of Educ., 550 U.S. 81, 89 (2007) (stating that the Court will uphold an administrative agency's reasonable interpretation of an ambiguous statute). 
- in the absence of information to establish a definition, resort to the default definitions of terms set forth in the Rules of Construction Act, 1 U.S.C. $\S 1$, if available. ${ }^{76}$

In addition, there are a number of grammar, punctuation, and syntax canons. These include the "rule of the last antecedent"" understanding that "may" implies discretion, ${ }^{78}$ "shall" implies something mandatory or less discretionary, ${ }^{79}$ and "or" is disjunctive rather than conjunctive. ${ }^{80}$

Additionally, there are widely accepted canons regarding what might be termed the structural or "textual integrity of the statute." 81 Among these are:

- the whole act rule, which provides that particular terms or provisions of a statute must be construed with reference to the entire statute and the commands and goals of the legislation; ${ }^{82}$

- the presumption of purposive amendment, which is the view that amendments to a statute, unless specifically denominated as "housekeeping" amendments, are designed to have a significant substantive impact on the statute and its meaning; ${ }^{83}$

- a preference for the avoidance of broad constructions of the statute unless justified by the statutory language or indications that Congress intended the statute to have broad construction; ${ }^{84}$

76. See ESKRIDGE ET AL., supra note 35, app. B, at 21; see, e.g., Stewart, 543 U.S. at 488 (noting that the Rules of Construction Act provides the default definition of "vessel").

77. See ESKRIDGE ET AL., supra note 35, app. B, at 21; see, e.g., Nobelman v. Am. Sav. Bank, 508 U.S. 324, 330-31 (1993) (articulating the rule of the last antecedent).

78. See ESKRIDGE ET AL., supra note 35, app. B, at 21; see, e.g., Jama v. Immigration \& Customs Enforcement, 543 U.S. 335, 346 (2005) (providing that “may” implies discretion).

79. See ESKRIDGE ET AL., supra note 35, app. B, at 21; see, e.g., Mallard v. United States Dist. Ct., 490 U.S. 296, 302 (1989) (stating that "shall” implies a command).

80. See ESKRIDGE ET AL., supra note 35, app. B, at 21.

81. See id.

82. See id.; see, e.g., Ledbetter v. Goodyear Tire \& Rubber Co., 550 U.S. 618, 630 (2007) (declining plaintiff's argument because it would be inconsistent with Title VII as a whole), superseded by statute, Lilly Ledbetter Fair Pay Act of 2009, Pub. L. No. 111-2, 123 Stat. 5 (codified as amended in scattered sections of 26 U.S.C.); Pavelic \& LeFlore v. Marvel Entm't Grp., 493 U.S. 120, 123 (1989) (holding a specific phrase of Rule 11 should be viewed in context of the rule as a whole), superseded by rule, FED. R. CIV. P. 11 (amended 1993).

83. See ESKRIDGE ET AL., supra note 35, app. B, at 23; see also FDA v. Brown \& Williamson Tobacco Corp., 529 U.S. 120, 144 (2000).

84. Id. at 159-60 (narrowly construing Congressional grants of authority to the FDA). This 
- the view that specific terms of a statute designed to deal with a particular issue are generally given greater weight than more general provisions of the statute ${ }^{85}$ and

- a view that exceptions to the reach of the statute expressed by the legislature should be strictly construed in order to prevent evisceration of the statute through expansive application of exceptions. $^{86}$

There is also judicial agreement tending to embrace canons expressing a preference for "continuity in law." ${ }^{87}$ Among these is a presumption of stare decisis, but acceptance that wrongly decided precedents can be overruled where the case for change is sufficiently compelling. ${ }^{88}$ In addition, there is a presumption against repeals by implication $^{89}$ and a presumption that statutory terms are used consistently across statutes. ${ }^{90}$ Related to these presumptions is the in pari materia rule providing that the use of similar statutory provisions in comparable statutes will be applied in the same way. ${ }^{91}$ There is also a canon that the views of a later Congress are generally not seen as illuminating the views of an enacting Congress. ${ }^{92}$

canon sometimes comes into tension with the canon that remedial legislation is to be liberally construed to implement its purpose.

85. See ESKRIDGE ET AL., supra note 35, app. B, at 23; see, e.g., Green v. Bock Laundry Mach. Co., 490 U.S. 504, 524-26 (1989) ("A general statutory rule usually does not govern unless there is no more specific rule.").

86. See ESKRIDGE ET AL., supra note 35, app. B, at 23; see, e.g., United States v. Smith, 499 U.S. 160, 167 (1991) ("Where Congress explicitly enumerates certain exceptions to a general prohibition, additional exceptions are not to be implied... [absent] contrary legislative intent." (quoting Andrus v. Glover Constr. Co., 446 U.S. 608, 616-17 (1980))).

87. See ESKRIDGE ET AL., supra note 35, app. B, at 25-26.

88. Id.

89. See id. app. B, at 26; see, e.g., Morton v. Mancari, 417 U.S. 535, 549-50 (1974) (calling the "presumption against repeals by implication" a "cardinal rule").

90. See ESKRIDGE ET AL., supra note 35, app. B, at 26; see, e.g., Pierce v. Underwood, 487 U.S. 552, 567-68 (1988) (discussing the interpretation of the meaning of "substantially justified" across statutes).

91. See ESKRIDGE ET AL., supra note 35, app. B, at 26; see, e.g., Ledbetter v. Goodyear Tire \& Rubber Co., 550 U.S. 618, 640-43 (2007) (analyzing arguments based on analogies to the EPA and FLSA in an EEOC claim), superseded by statute, Lilly Ledbetter Fair Pay Act of 2009, Pub. L. No. 111-2, 123 Stat. 5 (codified as amended in scattered sections of 26 U.S.C.). As observed above, Ledbetter was legislatively overruled in 2009 because of a widespread perception that the Court's holding was in error; the in pari materia canon, however, is widely followed by both liberals and conservatives, although they may of course differ in its application. See sources cited supra note 82.

92. See ESKRIDGE ET AL., supra note 35, app. B, at 28. 
In addition, there are also a number of canons reflecting substantive policy generally embraced by the courts. Despite the legal realist truth that judges can differ considerably in their personal preferences, the bench as a group appears to accept a basic core of substantive legal, political, and social substantive values as well as adherence to governing procedural rules. For example, a leading casebook divides these canons into several groups, including:

- federalism canons, which indicate (1) a strong presumption against statutory construction that would alter the federal-state balance of power, including a "super strong" rule against federal invasion of core state functions, ${ }^{93}$ and (2) a presumption against federal preemption of traditional state regulation, although this presumption can be overcome by clear statutory language or evidence of clear congressional purpose, so long as Congress has authority to so act pursuant to the Supremacy Clause; ${ }^{94}$ and

- due process canons and canons derived from common law, which include (1) a presumption against construing statutes in a manner that works to deny a jury trial otherwise available under the Constitution, ${ }^{95}$ (2) a presumption in favor of judicial review, ${ }^{96}$ and (3) a presumption in favor of enforcing forumselection clauses. ${ }^{97}$

As discussed below, the bulk of these canons or other conventions of statutory construction weigh against most pre-arbitration jurisprudence of the modern Court. The Court's support of arbitration is now so sufficiently established that legal scholars have posited that we now also have canons of construction favoring arbitration. ${ }^{98}$ This disturbing

93. See id. app. B, at 30.

94. See id., app. B, at 31; see, e.g., Rush Prudential HMO, Inc. v. Moran, 536 U.S. 355, 359 (2002) (holding that an Illinois statute did not conflict with ERISA's civil enforcement scheme); Cipollone v. Liggett Group, Inc., 505 U.S. 504, 530-31 (1992) (holding that the Federal Cigarette Labeling and Advertising Act did not preempt state law damages actions).

95. See ESKRIDGE ET AL., supra note 35, app. B, at 33.

96. See id.

97. See id.; e.g., Carnival Cruise Lines v. Shute, 499 U.S. 585, 589 (1991) (enforcing a forumselection clause because it was not fundamentally unfair); Stewart Org. v. Ricoh Corp., 487 U.S. 22, 33 (1988) (Kennedy, J., concurring) (observing that forum-selection clauses are enforceable and further vital interests of the justice system).

98. See ESKRIDGE ET AL., supra note 35, app. B, at 38 (noting that there is "[f]ederal court deference to arbitral awards, even where the Federal Arbitration Act is not by its terms applicable” 
development reflects the degree to which the Court's excessive affection for a particular concept has interfered with fair application of traditional tools of adjudication.

The legal profession should be hesitant to accept the premise that we have entered an era where there legitimately exists a "pro-arbitration" canon or set of canons. Although there appear to be broad social concerns about excessive litigation and a preference for less formal and combative modes of dispute resolution, ${ }^{99}$ it is not at all clear that the public and the body politic reflexively favor mandatory, privatized mass arbitration over litigation, mediation, or some government-administered hybrid such as court-annexed arbitration or an ombudsperson. ${ }^{100}$ To the contrary, employees, consumers, debtors, and state governments-large segments of society-appear to have significant objections to being "forced" to arbitrate due to judicial enforcement of broadly worded, standardized arbitration clauses embedded in contracts of adhesion. ${ }^{101}$

and stating that there exists a "[s]trong presumption in favor of arbitration" and a "[r]ule favoring arbitration of federal statutory claims").

99. See Jeffrey W. Stempel, Reflections on Judicial ADR and the Multi-Door Courthouse at Twenty: Fait Accompli, Failed Overture, or Fledgling Adulthood?, 11 Оніо ST. J. ON DisP. Resol. 297, 309-24 (1996) (reviewing the history of the modern ADR movement, which included both community efforts and rise of popularity of arbitration and mediation in business contexts). A major spur supporting ADR was the "Pound Conference" organized by Chief Justice Burger, which included prominent speakers criticizing excessive litigation and extolling the benefits of ADR. See id. at 316; see also Warren E. Burger, Isn't There a Better Way?, 68 A.B.A. J. 274, 276-27 (1982) (reflecting the former Chief Justice's strong support for arbitration and other forms of ADR and use of the bully pulpit of Chief Justiceship to promote both private and court-annexed arbitration).

100. See Stempel, Mandating, supra note 11, at 385-86 (2008) (noting the substantial differences between the traditional style of arbitration envisioned by the Congress that enacted the Federal Arbitration Act and the modern mass arbitration sought by vendors, lenders, and employers on the basis of broadly worded standardized clauses contained in contracts of adhesion deployed in high volume under circumstances where non-drafters have little or no appreciation of the existence of the arbitration agreement or its meaning); see also generally Linda J. Demaine \& Deborah R. Hensler, "Volunteering" to Arbitrate Through Predispute Arbitration Clauses: The Average Consumer's Experience, LAW \& CONTEMP. PROBS., Winter/Spring 2004, at 55, 62, 73 (outlining a study showing that nearly all consumer contracts of some type (e.g., cell phone contracts) have arbitration clauses but that consumers are largely ignorant of them).

101. See, e.g., Arbitrators, Civil Rights Groups Tell U.S. Supreme Court: Don't Erode Access to Courts, PUBLIC CiTIZEN (Apr. 1, 2010), http://www.citizen.org/pressroom/pressroomredirect.cfm? ID=3105 (describing "broad coalition of civil rights groups, labor unions and consumer advocacy organizations" that filed amici briefs opposing mandatory arbitration in Rent-A-Center); Mandatory Arbitration, PuBlic JusticE, http://www.publicjustice.net/Key-Issues-Cases/Access-To-Justice/ Mandatory-Arbitration.aspx (last visited Feb. 11, 2012) (describing the group's “Mandatory Arbitration Abuse Prevention Project”); Fair Arbitration, PuBliC CITIZEN, http://www.citizen.org/ Page.aspx?pid=2512 (last visited Feb. 11, 2012) (providing resources on taking action against forced arbitration and arbitration fairness); All Things Considered: Rape Case Highlights Arbitration Debate (NPR radio broadcast June 9, 2009), available at http://www.npr.org/templates/ story/story.php?storyId=105153315 (describing former Halliburton employee's efforts to combat 
One state attorney general brought charges that resulted in a large arbitration provider abandoning the field of debtor arbitration. ${ }^{102}$ There has also, of course, been substantial scholarly criticism of the enforcement of such clauses. ${ }^{103}$

These factors suggest that there is not a strong national consensus in favor of arbitration, regardless of the contextual factors of a given case and arbitration agreement. The pro-arbitration rejoinder to this observation, of course, is that there is a federal statute favoring arbitration that has been the law of the land since 1926, which is not bad support for a pro-arbitration canon of construction. But this still begs the question of whether the Arbitration Act, which was designed to foster specific enforcement of arbitration clauses in traditional commercial contracts among merchants, was ever meant to apply to the new mass arbitration and whether the now eighty-six-year-old act can be legitimately expanded by the judiciary to the point of fairly supporting the existence of a pro-arbitration canon.

Under the traditional approach to statutory construction, as discussed below in reviewing the Court's thirty-year embrace of arbitration, the answer would appear to be a clear "no." The intent and purpose of the Act was rather narrowly focused upon merchants rather than consumers, employees, or debtors and specifically exempted employees, although the courts aggressively confined the scope of this exception, even prior to the modern Supreme Court amore for arbitration. ${ }^{104}$ Much of the pro-

mandatory arbitration clauses).

102. See In re Nat'l Arbitration Forum Trade Practices Litig., 704 F. Supp. 2d 832, 835 (2010) ("On July 14, 2009, the Minnesota Attorney General brought a complaint in Hennepin County against NAF alleging consumer fraud act and deceptive trade practices act violations and false advertising. NAF settled that litigation less than a week later, agreeing to cease performing consumer arbitrations and entering into a consent judgment to that effect with the Minnesota Attorney General.”); Kathy Chu \& Taylor McGraw, Minnesota Lawsuit Claims Credit Card Arbitration Firm Has Ties to Industry, U.S.A. TODAY, July 15, 2009, at 6A; Carrick Mollenkamp, et al., Turmoil in Arbitration Empire Upends Credit-Card Disputes, WALl ST. J., Oct. 15, 2009, at A14 ("NAF settled the case with Minnesota Attorney General Lori Swanson in July without admitting the charges. It agreed in the settlement to stop arbitrating credit-card cases nationwide."); see also Tom Abate, Arbitration Firm Calling It Quits, S.F. CHRON., July 22, 2009, at C1 (describing similar lawsuit by the San Francisco city attorney's office against the NAF); Sam Zuckerman, S.F. Sues Credit Card Service, Alleging Bias, S.F. CHRON., Apr. 8, 2008, at D1 (same).

103. See, e.g., Paul D. Carrington, Unconscionable Lawyers, 19 GA. ST. U. L. REV. 361, 373-79 (2002); Kenneth R. Davis, The Arbitration Claws: Unconscionability in the Securities Industry, 78 B. U. L. REV. 255 (1998) ; Russell D. Feingold, Mandatory Arbitration: What Process Is Due?, 39 HARV. J. ON LEGIS. 281 (2002); Schwartz, supra note 27; Sternlight, supra note 15; Jean R. Sternlight, Creeping Mandatory Arbitration: Is It Just?, 57 STAN. L. REV. 1631 (2005).

104. See Stephen K. Huber \& Maureen A. Weston, Arbitration: Cases and Materials 9-11 (3d ed. 2011) (describing the background of the Act and other arbitration legislation such as 
arbitration jurisprudence of the last thirty years has emerged because the Court failed to faithfully apply more long-standing canons and principles of statutory construction. Particularly disappointing is the Court's unwillingness to follow statutory text or legislative history when it argues against arbitration and the Court's failure to appreciate the federalism implications of Court decisions riding roughshod over the states' traditional powers of contract construction and policing of allegedly unfair contracts. ${ }^{105}$

Under these circumstances, it would be a mistake via illegitimate fait accompli to attempt to defend the current Court's arbitration decisions as justified according to a perceived pro-arbitration canon of construction. It is also a bit of a tautology for a court to construe a statute concerning arbitration through the lens of a pro-arbitration canon. The very object of the exercise of judicial scrutiny is to assess the meaning of the arbitration statute. Resort to a mythical pro-arbitration canon prejudges the issue and short circuits the judicial process.

Although there has not been a great amount of systematic empirical analysis of the individual Justices' use of the canons, it appears that the more politically and jurisprudentially conservative Justices make more frequent use of the canons, perhaps as an alternative to greater resort to legislative history or more open-ended public policy analyses. ${ }^{106}$ For example, Justice Scalia has made use of the canons, presumably because this permits him to better construe statutory language without resort to legislative history. ${ }^{107}$

the Uniform Arbitration Act and Labor Management Relations Act, which covers labor arbitration); LEONARD L. RISKIN ET AL., DisPUTE RESOLUTION AND LAWYERS 554-63 (4th ed. 2009) (describing the background of the Arbitration Act); Jeffrey W. Stempel, Pitfalls of Public Policy: The Case of Arbitration Agreements, 22 ST. MARY's L.J. 259, 277-83 (1990) (describing the Act's "genesis, thrust and context”).

105. See infra notes 355-74 and accompanying text (discussing Stolt-Nielsen); infra notes 386423 and accompanying text (discussing Concepcion).

106. See James Brudney \& Corey Ditslear, Canons of Construction and the Elusive Quest for Neutral Reasoning, 58 VAND. L. REV. 1, 52-53, 57-63 (2005) (noting the degree to which conservative Justices invoke canons of construction more frequently than liberal Justices and that the Rehnquist Court utilized canons more frequently than the less conservative Burger Court); see also ESKRIDGE ET AL., supra note 35, at 951 (referencing Circuit City as an example of result-oriented invocation of canons by conservative majority and noting that "[a] neutral observer who just read the statute and the legislative history in Circuit City, for example, would have expected the Court to read the labor exemption to the Arbitration Act much more expansively than the five-Justice majority in fact did").

107. See, e.g., Bryan v. United States, 524 U.S. 184, 200-01 (1998) (Scalia, J., dissenting) (calling for application of the canon requiring doubts to be resolved in favor of the defendant where there is ambiguity in a criminal statute); Babbitt v. Sweet Home Chapter of Cmtys. for a Great Or., 


\section{F. More Controversial Approaches to Statutory Construction}

As noted above, the mainstream approach to statutory construction embraced by the Justices generally begins with and emphasizes text but also considers legislative intent and purpose to the degree appropriate so long as it does not strain the reading of the text. The Court as a whole seems to have been less willing, or perhaps even unwilling, to endorse some of the less-established modes of statutory interpretation, which enjoy support in the academic community. Among these are considerations of public policy, appreciation of interest group influence on legislation, and the view that construction of legislation should evolve with changing circumstances. ${ }^{108}$ In practice, however, it appears that courts use a variety of approaches that permit them to exercise more personal preferences than courts are willing to acknowledge. ${ }^{109}$ In addition, there are questions of the role of the executive branch and administrative agencies in the construction of statutes. ${ }^{110}$

Against this backdrop of the generally-agreed-upon ground rules of statutory construction, the Court's jurisprudence-even when it was less enamored of arbitration-is not a particularly fine example of judicial craft. Under "normal" circumstances where the Justices consistently applied the agreed rules of statutory interpretation, one would expect to see consistent fidelity to clear text, an effort to vindicate any fairly discernible specific intent of the enacting Congress, decisions consistent

515 U.S. 687, 720-21 (1995) (Scalia, J., dissenting) (applying the canon noscitur a sociis); Chisom v. Roemer, 501 U.S. 380, 404 (1991) (Scalia, J., dissenting) (describing the "regular method" for interpreting statutory language as follows: "first, find the ordinary meaning of the language in its textual context; and second, using established canons of construction, ask whether there is any clear indication that some permissible meaning other than the ordinary one applies").

108. See, e.g., William N. Eskridge, JR., DyNAmic Statutory InTERPRETATION (1997) (arguing that construction of statutes should evolve with changes in society, economics, and business in a manner consistent with the purposes of the enacting legislatures); see also GUIDO CALABRESI, A COMMON LAW FOR THE AGE OF STATUTES (1982) (suggesting that older statutes should be treated like common law precedents that can, in compelling cases, be "overruled" by courts); William N. Eskridge, Jr., Public Values in Statutory Interpretation, 137 U. PA. L. REV. 1007 (1989) (noting public policy considerations are frequently, if tacitly, used by courts in deciding cases and finding such use appropriate and legitimate but questioning particular values emphasized in certain decisions); Richard Stewart, The Reformation of Administrative Law, 88 HARV. L. REV. 1669, 168384, 1813 (1975) (noting rising interest group influence on modern legislation and administrative agency action but diffuse as to recommended reaction). See generally ESKRIDGE ET AL., supra note 35, Chs. 6-8 (reviewing approaches to statutory construction).

109. See Eskridge \& Frickey, Statutory Interpretation, supra note 43, at 324-45.

110. See Cass Sunstein, Interpreting Statutes in the Regulatory State, 103 HARV. L. REV. 405, 413 (1989) (noting that statutory interpretation extends to administrative agencies attempting to implement statutes). 
with the overall purpose of the statute, and respect for traditional state law prerogatives unless areas of state autonomy were clearly superseded by a valid exercise of congressional power. Instead, we see a mixed pattern of decision-making during the first six decades of the Act, followed by growing infatuation with arbitration, reduced adherence to the traditional ground rules of statutory construction, and most recently, an appallingly bad decision-Concepcion-that tramples upon traditional state contract prerogatives, federal civil disputing policy, and the legislative intent and purpose underlying the Act.

\section{THE PATH OF TAINTED LOVE: TRACKING THE COURT’S ARBITRATION DECISIONS}

As Shakespeare famously observed, "[t]he course of true love never did run smooth." 111 So it is with tainted love as well. Before the modern Supreme Court's infatuation with arbitration, there was substantial resistance, and sometimes outright hostility, to arbitration clauses because they were seen as improperly depriving courts of jurisdiction. The Federal Arbitration Act was prompted in large part by the business community's dismay over such decisions and its persuasion of Congress that legislative overruling of anti-arbitration decisions was in order. ${ }^{112}$

A personal favorite illustration of pre-Act judicial hostility to arbitration is Rederiaktiebolaget Atlanten v. Aktieselskabet Korn-Og Foderstof Kompagniet, often also known as the Atlanten or Korn-Og. ${ }^{113}$ In this case, decided shortly before the enactment of the Federal Arbitration Act, the Court, affirming a Learned Hand trial court decision and a Second Circuit decision, held that even what appeared to be a broadly worded arbitration clause in a shipping contract between merchants - with no discernible issues of consumer protection, consent, etc.- does not require arbitration. ${ }^{114}$ The Court reasoned that the

111. See William ShaKesPeAre, A Midsummer NighT's DreAm act 1, sc.1.

112. See Jeffrey W. Stempel, A Better Approach to Arbitrability, 65 TuL. L. REV. 1377, 1380 (1991) (describing the historical judicial resistance to arbitration and the response by businesses and legislators culminating in the Federal Arbitration Act); Stempel, supra note 104, at 270-90 (noting the degree to which some modern courts as late as the 1980s continued to resist enforcement of arbitration agreements based on problematic "public policy" concerns about arbitration).

113. 252 U.S. 313, 315-16 (1920), aff'g 250 F. 935 (2d Cir. 1918), aff'g 232 F. 403 (S.D.N.Y. 1916).

114. The arbitration clause in question included the following provision:

If any dispute arises the same to be settled by two referees, one to be appointed by the

Captain and one by charterers or their agents, and if necessary, the arbitrators to appoint 
arbitration clause was inapplicable because one party sought to arbitrate an issue of breach of contract because the claim arose out of a breach of the contract and not an issue related to performance of the contract. ${ }^{115}$

Cases like Korn-Og were not that unusual. English courts resisted specific enforcement of arbitration clauses on the ground that they improperly ousted courts of their rightful jurisdiction, a view that was largely adopted in the United States. In reaction, the commercial community sought corrective legislation and obtained it with passage of the Act, now codified at 9 U.S.C. $\S \S 1-16 .{ }^{116}$

\section{A. The Federal Arbitration Act}

The Act itself, which was passed in 1925 and had an effective date of January 1, 1926, ${ }^{117}$ is rather short and straight-forward. After defining key terms such as "commerce" and "maritime," the Act states:

A written provision in any maritime transaction or a contract evidencing a transaction involving commerce to settle by arbitration a controversy thereafter arising out of such contract or transaction, or the refusal to perform the whole or any part thereof, or an agreement in writing to submit to arbitration an existing controversy arising out of such a contract, transaction, or refusal, shall be valid, irrevocable, and enforceable, save upon such grounds as exist at law or in equity for the

an Umpire. The decision... shall be final, and any party attempting to revoke this submission to arbitration without leave of a court shall be liable to pay to the other or others, as liquidated damages, the estimated amount of chartered freight. Id. at 315 .

115. See Aktieselskabet Korn-Og Foderstof Kompagniet v. Rederiaktiebolaget Atlanten, 232 F. 403, 405 (S.D.N.Y. 1916) ("The theory appears to be that such a provision is part of the execution of the contract, a piece of its administration, and ought not to be construed as applicable to an entire change of purpose which results in the abandonment by one party of the enterprise as a whole.”). The logic and anti-arbitration effect of Korn-Og is baffling and shows that even great minds like Learned Hand can have bad days.

116. See Stempel, supra note 104, at 321-23 (summarizing pre-Act common law resistance to arbitration and the gestation and passage of the Act).

117. United States Arbitration Act, Pub. L. 68-401, 43 Stat. 883 (1925) (codified at 9 U.S.C. § 14 (2006)). Section 1 of Pub. L. No. 282, 61 Stat. 669 (1947) was codified and enacted into positive law in Title 9 of the U.S. Code. Prior to that, the text of Title 9 containing the Act had been legally viewed as "merely prima facie evidence of the law." S. REP. No. 664, 80th Cong., 1st Sess. 1 (1947); see Philip E. Karmel, Note, Injunctions Pending Arbitration and the Federal Arbitration Act: A Perspective from Contract Law, 54 U. CHI. L. ReV. 1373, 1373 n.2 (1987); Wesley A. Sturges \& Irving Olds Murphy, Confusing Matters Relating to Arbitration Under the United States Arbitration Act, 17 LAW \& CONTEMP. PROBS. 580, 580 (1952). 
revocation of any contract. ${ }^{118}$

Section 3 provides that courts may issue a stay of judicial proceedings in order to permit arbitration to proceed pursuant to an enforceable agreement. ${ }^{119}$ Section 4 gives federal courts authority to enter an order compelling arbitration if the petitioning party to a valid arbitration agreement is "aggrieved by the alleged failure, neglect, or refusal of another to arbitrate." ${ }^{20}$ Several sections of the Act deal with procedural matters. $^{121}$

The Act provides strong support for enforcing arbitration awards, specifying that federal courts may confirm awards and enter judgment based on the award, ${ }^{122}$ which in turn gives the prevailing arbitration party the normal range of judgment collection tools under applicable procedural law. Section 10 of the Act permits arbitration awards to be challenged, but on grounds considerably narrower than those available in litigation, specifically:

(1) where the award was procured by corruption, fraud, or undue means;

(2) where there was evident partiality or corruption in the arbitrators, or either of them;

(3) where the arbitrators were guilty of misconduct in refusing to postpone the hearing, upon sufficient cause shown, or in refusing to hear evidence pertinent and material to the controversy, or any other misbehavior by which the rights of any party have been prejudiced; or

(4) where the arbitrators exceeded their powers, or so imperfectly executed them that a mutual, final, and definite award upon the subject matter submitted was not made. ${ }^{123}$

The final section of the Act governs appeals and reflects the

118. 9 U.S.C. § 2 (2006).

119. Id. § 3 .

120. Id. § 4 .

121. See, e.g., id. $\S 5$ (governing the appointment of arbitrators); id. $\S 6$ (providing that applications for relief are treated as motions); id. § 7 (allowing for use witnesses and subpoenas, and setting fees); id. § 8 (subjecting admiralty matters, such as seizure of vessels, to arbitration); id. § 11 (regulating modification and correction of errors in an arbitration award); id. § 13 (governing papers and docketing); id. § 15 (providing for the inapplicability of the "Act of State" doctrine).

122. Id. § 9 .

123. Id. § 10. Section 10 also specifically provides that a reviewing court may direct a rehearing by the arbitrators if a ground for vacating the award is shown. Id. 
congressional preference-largely through the 1990 amendments rather than the original 1925 enactment - to reduce appellate challenges to proarbitration orders but to permit appellate review of orders refusing to 
compel arbitration or refusing to stay judicial proceedings pending arbitration. ${ }^{124}$

\section{B. The First Five Decades of Construing the Arbitration Act}

Despite passage of the Act, there remained some judicial resistance to arbitration, as occasionally reflected in case law over the next fifty years. Most prominent was Wilko v. Swan, which held-seemingly out of the blue-that claims arising under the Securities Act of 1933 were not subject to arbitration, regardless of the clarity of the arbitration clause, the knowing and voluntary consent of the parties, the standard practice of the industry, or the expectations of the parties. ${ }^{125}$

In a similar vein was Bernhardt v. Polygraphic Co. of America, ${ }^{126}$ which the Court implicitly revisited and reversed in the watershed Southland Corp. v. Keating ${ }^{127}$ decision. In Bernhardt, the Court held that the Arbitration Act was procedural rather than substantive and consequently was subject to the Erie doctrine, which made Vermont law applicable in the instant case. ${ }^{128}$ Under Vermont law, an arbitration agreement of the type at bar was unenforceable. ${ }^{129}$ Hence, arbitration was not required, regardless of the contracting circumstances. ${ }^{130}$

The Court took a more receptive approach to arbitration in the context of labor arbitration in the Steelworkers Trilogy, three cases involving disputes between the then-powerful United Steelworkers union and companies with which it had collective bargaining agreements providing for arbitration of workplace disputes. ${ }^{131}$ Some argue that these

124. Section 16 states that "an appeal may not be taken from an interlocutory order” granting a stay of litigation, directing/compelling arbitration, or refusing to enjoin an arbitration except pursuant to 28 U.S.C. $\S 1292$ (b), which permits trial courts to certify for immediate review decisions involving close legal questions where the judge believes earlier appellate review will expedite ultimate disposition of the matter. Id. § 16(b)(1)-(4); 28 U.S.C. § 1292(b) (2006).

125. 346 U.S. 427, 438 (1953) (ruling that enforcing an agreement to arbitrate was tantamount to permitting a waiver of the substantive protections of the $1933 \mathrm{Act}$ ), overruled by Rodriguez de Quijas v. Shearson/Am. Express, Inc., 490 U.S. 477 (1989). The dissenting Justices objected on the ground that a forum selection clause requiring arbitration did not deprive a claimant of the substantive benefits of the Act. Id. at 440 (Frankfurter, J., dissenting).

126. 350 U.S. 198 (1956)

127. 465 U.S. 1 (1984).

128. 350 U.S. at 208.

129. Id. at 204-06.

130. See id. Bernhardt was a diversity case, prompting the Court to apply the Erie doctrine in concluding that rather than enforcing the Arbitration Act, the federal court sitting in diversity should apply Vermont law, which prevented specific enforcement of arbitration agreements. Id. at 212.

131. United Steelworkers v. Am. Mfg. Co., 363 U.S. 564, 564-66 (1960); United Steelworkers v. 
cases-rather than the Court's 1980s cases promoting arbitrationcomprise the inauguration of the modern era of Supreme Court precedent favoring arbitration. ${ }^{132}$ In United Steelworkers $v$. American Manufacturing Co. and United Steelworkers v. Warrior \& Gulf Navigation Co., the Court enforced arbitration agreements. ${ }^{133}$ In United Steelworkers v. Enterprise Wheel \& Car Corp., the Court announced a very deferential standard for the review of labor arbitration decisions, holding that the decision would be confirmed by courts so long as the arbitrator's decision "draws its essence" from the agreement. ${ }^{134}$ A cynic might note that even a horribly erroneous decision can still deal with the essence or core of the agreement giving rise to the dispute.

Because these three cases were so focused on labor arbitration rather than commercial or consumer arbitration, they can be considered precursors to the modern era. To be sure, the Court showed signs of greater affection for arbitration, but that resulted largely from the Court's view that arbitration is a particularly critical component of the collective bargaining process and an established means by which labor peace is preserved. ${ }^{135}$ As the Court's other 1960s and 1970s cases show, the

Warrior \& Gulf Navigation Co., 363 U.S. 574, 575-77 (1960); United Steelworkers v. Enter. Wheel \& Car Corp., 363 U.S. 593, 594-96 (1960).

132. See Linda R. Hirchsman, The Second Arbitration Trilogy: The Federalization of Arbitration Law, 71 VA. L. REV. 1305, 1306 (1985) (viewing the Steelworkers Trilogy as important but seeing Dean Witter Reynolds, Inc. v. Byrd, Moses H. Cone Memorial Hospital v. Mercury Construction, and Southland Corp. v. Keating as a "second" important arbitration trilogy); see also infra notes 162-222 and accompanying text (discussing Byrd, Moses H. Cone, and Southland).

133. See Am. Mfg., 363 U.S. at 567-69; Warrior, 363 U.S. at 581-85.

134. See Enterprise Wheel, 363 U.S. at 597-99. The Enterprise Wheel standard of review of labor arbitration awards actually differs from the standard of review set forth in section 11 of the Federal Arbitration Act, which underscores the longstanding view that the Act was aimed directly at commercial arbitration. Id.; 9 U.S.C. § 11. In the Steelworkers Trilogy, the Court fashioned labor arbitration law on the strength of Section 301 of the Labor Management Relations Act, which the Court has construed to provide authority for common law development of federal labor law. Warrior, 363 U.S. at 577-78; see Textile Workers Union v. Lincoln Mills, 353 U.S. 448, 456 (1957) (holding that federal law applies to suits under § 301(a)); 29 U.S.C. § 185 (2006).

Under the Federal Arbitration Act, an arbitration award is presumptively valid unless the arbitrators have exceeded their powers or acted with bias or favoritism. See 9 U.S.C. § 2; Moses H. Cone Mem'l Hosp. v. Mercury Constr. Corp., 460 U.S. 1, $24-25$ (1983). Although this may not be much different in practice than the Enterprise Wheel "draws-its-essence-from-the-agreement test," one can make a strong case that the same standard should apply to review of both labor and commercial arbitration awards. See Mark W. Lee, Note, Judicial Review of Labor Arbitration Awards: Refining the Standard of Review, 11 WM. MitcheLl L. REV. 993, 1011-17 (1985) (arguing that the Act's standard better serves the public policy favoring labor arbitration).

135. See Am. Mfg., 363 U.S. at 567-69 ("Arbitration is a stabilizing influence only as it serves as a vehicle for handling any and all disputes that arise under the agreement.”). 
Court was warming to arbitration but continued to have doubts about it outside the labor arena. ${ }^{136}$

In Moseley v. Electronic \& Missile Facilities, Inc., a plumbing and heating subcontractor filed suit in Georgia to collect funds allegedly owed it by the general contractor for a United States government missile site and successfully resisted arbitration even though the contractor had previously filed an action in New York seeking to enforce the arbitration clause. ${ }^{137}$ The Court found that the subcontractor had adequately alleged an issue regarding possible fraud regarding the procurement of the arbitration agreement. ${ }^{138}$ This seems a classic case of "old" or traditional commercial arbitration rather than the "new" or "mass" arbitration of retail consumer matters that has troubled many. ${ }^{139}$ One might argue, however, that the terms of the arbitration agreement unfairly subjected the subcontractor to a seriously inconvenient forum. ${ }^{140}$ Notwithstanding the Steelworkers Trilogy, Moseley suggested the Court's continuing wariness toward arbitration. ${ }^{141}$

In Prima Paint Corp. v. Flood \& Conklin Manufacturing Co., the Court held (arguably overruling Moseley) that a question of fraudulent inducement as to the contract containing an arbitration clause was in the first instance a question for the arbitrator. ${ }^{142}$ By giving arbitrators "first dibs" on these questions, the Court appeared to approach a more favorable attitude toward arbitration. ${ }^{143}$ Continuing this substantial deference to private dispute resolution agreements, the Court in Bremen v. Zapata Off-Shore Co. enforced a forum selection clause in a maritime towing agreement, even though the party adhering to the towing contract had relatively little bargaining power in light of the disabled condition of its vessel. ${ }^{144}$ The case was regarded as a sign that the Court was beginning to look more favorably on such private dispute resolution agreements. ${ }^{145}$ Logically, this suggested a similar shift in the Court's

\footnotetext{
136. See infra text accompanying notes $137-61$.

137. 374 U.S. 167, 168-71 (1963).

138. See id. at $170-72$.

139. See supra notes $1-16$ and accompanying text (discussing distinctions between traditional, individualized, "old" style commercial arbitration and "new" standardized mass arbitration of consumer, employment, and debtor-creditor disputes); see also Stempel, supra note 15.

140. See Stempel, supra note 112, at 1397 (discussing Moseley in detail).

141. Id.

142. 388 U.S. 395, 403-04 (1967).

143. See id. 403-06; Stempel, supra note 112, at 1390-92 (discussing Prima Paint).

144. See 407 U.S. 1, 9-20 (1972).

145. See Harold G. Maier, The Three Faces of Zapata: Maritime Law, Federal Common Law,
} 
attitude toward arbitration agreements. Zapata is another precursor to the modern era, however, because it was a case of traditional commercial arbitration rather than of new mass arbitration affecting consumers.

Merrill Lynch, Pierce, Fenner \& Smith, Inc. v. Ware involved a dispute over wage claims. ${ }^{146}$ The Court refused to enforce the standard arbitration clause signed by workers in the financial services industry as a condition of their employment because of a state law prohibiting arbitration of wage claims. ${ }^{147}$ Although this decision is now effectively overruled by Southland and its progeny, ${ }^{148}$ the latter cases are arguably distinguishable in that the state law in Ware appears more directly aimed against arbitration, while the state law in Southland was applicable to any contract provisions waiving substantive rights as a condition of obtaining a franchise. ${ }^{149}$ In view of the Court's most recent arbitration decision in AT\&T Mobility LLC v. Concepcion, which refused to apply state contract law to arbitration agreements despite the language of the Federal Arbitration Act inviting its application, ${ }^{150}$ Ware is effectively dead (absent a change in Court composition and a willingness to re-examine the issue) and represents the Court's old skeptical concern about arbitration rather than its newfound affection for arbitration. ${ }^{151}$

Federal Courts Law, 6 VAND. J. TRANSNAT’L L. 387, 398 (1973) (“When [Prima Paint] is read together with Zapata one conclusion that can reasonably be drawn is that all agreements to arbitrate as well as all reasonable selections of forums in international commercial contracts will be enforced in the federal courts.”); Linda S. Mullenix, Another Choice of Forum, Another Choice of Law: Consensual Adjudicatory Procedure in Federal Court, 57 FoRDHAM L. REV. 291, 307 n.49 (1988) (gathering commentary regarding Zapata); Kurt H. Nadelmann, Choice-of-Court Clauses in the United States: The Road to Zapata, 21 AM. J. CoMP. L. 124, 127 (1973) (noting Zapata brought a "more favorable climate for forum selection clauses"); Willis L. M. Reese, The Supreme Court Supports Enforcement of Choice of Forum Clauses, 7 INT'L LAW. 530, 537 (1973) ("The initial judicial hostility to such clauses appears to be on the wane ....”).

146. 414 U.S. 117,119 (1973).

147. Id. at $119-25,140$.

148. See infra notes 169-214 and accompanying text (discussing Southland and its overruling of Bernhardt).

149. See Cal. Civ. Proc. Code $\S 1281.2$ (West 2007) (“[T]he court shall order the petitioner and the respondent to arbitrate the controversy if it determines that an agreement to arbitrate the controversy exists.”); Ware, 414 U.S. at 122-23.

150. See infra notes 386-423 and accompanying text (discussing Concepcion).

151. The issue of permissible state "interference" with arbitration is even a bit more complicated because, in Doctor's Associates v. Casarotto, the Court struck down a Montana law requiring that arbitration clauses in franchise agreements comply with certain disclosure requirements. 517 U.S. 681, 689 (1996). Casarotto clearly seems to constructively overrule Ware. See id. But in AT\&T Mobility $L L C$ v. Concepcion, the Court astonishingly suggested that even though it was preventing application of California's judicially crafted doctrine of unconscionability as a contract defense, the states might be free to enact the type of specific legislation that Court had struck down in Casarotto. See infra notes 413-21 and accompanying text (discussing this aspect of Concepcion). 
A year after Ware, in Scherk v. Alberto-Culver Co., the Court enforced an arbitration clause-one calling for arbitration in Francecontained in a sale-of-business agreement between a businessperson and a large multinational company. ${ }^{152}$ Although a trip to France is hardly the greatest dispute resolution burden one might face, the Court's enforcement reflects its general comfort with arbitration, at least in the commercial context. But, as in Zapata, the Court was dealing with oldstyle commercial arbitration and not the new mass arbitration of consumer complaints that would arise as a consequence of the Court's pro-arbitration jurisprudence. ${ }^{153}$ Even so, scholarly discussion of the decision expressed concern that the franchisee dealing with the manufacturer might lack sufficient independence, savvy, and bargaining power, as well as concern that the language and reasoning of Scherk could lead to more aggressive enforcement of arbitration clauses contained in consumer contracts. ${ }^{154}$

As of the mid-1970s, the Court's approach could be characterized as one of greater acceptance of arbitration but with some continuing concern or even outright hostility when arbitration clauses swept statutory claims within their textual ambit. For example, in Alexander $v$. Gardner-Denver Co., the Title VII claim of a union employee was held to be beyond the scope of the arbitration clause contained in the

152. 417 U.S. 506, 508-09, 512-20 (1974).

153. Id. at 517; see supra notes $144-45$ and accompanying text.

154. See, e.g., C. Edward Fletcher, III, Privatizing Securities Disputes Through the Enforcement of Arbitration Agreements, 71 MinN. L. REV. 393, 408 (1987) ("Scherk is most commonly acknowledged as standing for the proposition that international securities transactions are not subject to the Wilko limitation on the enforceability of arbitration clauses. The case, however, stands for much more than that."); Samuel H. Gruenbaum, Avoiding the Protections of the Federal Securities Laws: The Anti-Waiver Provisions, 20 SANTA ClARA L. REV. 49, 57 (1980) (“[T]he Court in Scherk does not appear to have limited its rationale to 'truly international transactions.' On the contrary, it implied rather strongly that its holding applied to transactions having fewer foreign contacts than the transaction in Scherk.") ; Brett Robert Chapman, Comment, The Case for Domestic Arbitration of Federal Securities Claims: Is the Wilko Doctrine Still Valid?, 16 Sw. U. L. REV. 619, 641 (1986) ("The Supreme Court took care in both Mitsubishi and Scherk to distinguish the decisions from their domestic equivalent. This distinction is without merit, for both decisions rest on an implied recognition of the capabilities of foreign arbitral tribunals to make subjective findings of intent and knowledge involving complex statutory rights. No rational basis exists for continued denial of similar capabilities in their domestic counterparts.”); Gail Elaine Papermaster, Note, Will the Courts Sherck The Little Old Lady in Dubuque? The Impact of Scherk v. Alberto-Culver on the Individual Investor in a Global Securities Market, 21 TEX. INT'L L.J. 129, 146-47 (1985) (“The existence of unequal bargaining power at the time an agreement is made argues strongly for inapplicability of Scherk .... "); Stephen C. Sieberson, Note, Scherk v. Alberto-Culver Co. and Arbitration Under the Securities Exchange Act: A Comity of Errors, 1 J. CORP. L. 100, 119 (1975) ("The most satisfying formulation would be one that focuses on the bargaining posture of the securities buyer.”). 
collective bargaining agreement to which he was subject. ${ }^{155}$ Although the decision can be fairly regarded as one merely interpreting the scope of the arbitration clause and the nature of union-management dispute resolution as opposed to a civil rights claim, the decision can also be read as one applying a statutory or public policy exception to the Arbitration Act. ${ }^{156}$ In any event, Alexander suggested that the Court remained at least mildly skeptical about arbitration in some contexts.

For example, in Barrentine v. Arkansas-Best Freight System, Inc., the Court held that a broadly worked arbitration clause in a collective bargaining agreement did not apply to the workers' Fair Labor Standards Act claims. ${ }^{157}$ Barrentine stands pretty clearly as a case applying a "statutory" claims exception to arbitration in the manner of Wilko $v$. Swan. ${ }^{158}$ After Barrentine, the Court, although not overtly hostile to arbitration, continued to limit its reach and deny arbitrability for certain types of cases. ${ }^{159}$ In McDonald v. City of West Branch, in a fashion quite similar to Barrentine, the Court refused to compel arbitration of civil rights claims made pursuant to 42 U.S.C. $§ 1983,{ }^{160}$ suggesting that the Court had not yet fully embraced arbitration. ${ }^{161}$

\section{The Modern Era of Arbitration at the Court}

Within a short time after McDonald, the Court's affection for arbitration solidified. Despite early-1980s cases such as Barrentine and McDonald that reflected continued wariness about arbitration, by the mid-1980s the Court had embarked on a new path. Decided during the same term as McDonald, the Court in Moses H. Cone Memorial Hospital v. Mercury Construction Corp. enforced an arbitration agreement in a dispute over a construction project between the buyer-hospital and the general contractor. ${ }^{162}$ The hospital sought a state court order staying arbitration proceedings notwithstanding that the construction contract

\footnotetext{
155. See 415 U.S. 36, 38-43, 59-60 (1974).

156. See Stempel, supra note 104, at 321-23.

157. 450 U.S. $728,730,745$ (1981).

158. See id. at 740; supra notes 125 and accompanying text.

159. See Stempel, supra note 104, at 308-19 (discussing Barrentine).

160. 466 U.S. 284, 285 (1984).

161. See Stempel, supra note 104, at 323-27 (discussing McDonald).

162. 460 U.S. 1, 5, 29 (1983), superseded by statute on other grounds, Federal Arbitration Act, 9 U.S.C. § 16(b)(1) (2006).
} 
contained a broadly worded arbitration clause committing all such contracts-related disputes to arbitration. ${ }^{163}$

The Court's decision to compel arbitration and reject the view that Colorado River abstention ${ }^{164}$ was required of the federal court by notions of deference to ongoing state proceedings ${ }^{165}$ made eminent sense. In dissent, however, Chief Justice Burger and Justices Rehnquist and O'Connor argued that in its zeal to render the pro-arbitration ruling, the majority had been too quick to find a sufficiently final order that permitted appeal. ${ }^{166}$ Legal realists might also note with some irony that in Moses H. Cone, it was three of the Court's Republican-appointed conservatives who had misgivings about the pro-arbitration resultexactly the opposite of the trend in the current Court.

What prompts some to see Moses $H$. Cone as the dawn of the modern pro-arbitration era is its rhetoric favoring arbitration. ${ }^{167}$ More substantively, the Moses $H$. Cone majority states that the Act "create[s]... a substantive law of arbitrability applicable to any arbitration agreement within the coverage of the Act." ${ }^{\text {"68 }}$ In other words, the Act appeared to apply in state courts as well as in federal court. But this issue was not prominently addressed until the Court's next important arbitration case. Although the Moses H. Cone decision favored arbitration, it was not the full-fledged infatuation that came in Southland Corp. v. Keating, ${ }^{169}$ which most regard as the dawn of the Court's modern pro-arbitration jurisprudence.

163. Id. at $5-7$.

164. Colorado River abstention, named after Colorado River Water Conservation Dist. v. United States, 424 U.S. 800, 817-21 (1976), occurs when a federal court dismisses or stays proceedings based on the existence of concurrent state court proceedings involving the same parties and controversy. See Roger S. HAYdOCK, DAVID F. HERR \& JEFFREY W. STEMPEL, FUNDAMENTALS OF PRETRIAL LitigATION § 4.5 (8th ed. 2011).

165. See Moses H. Cone, 460 U.S. at 13-23.

166. See id. at 30 (Rehnquist, J., dissenting).

167. See, e.g., id. at 24 (majority opinion) (viewing section 2 of the Federal Arbitration Act as "a congressional declaration of a liberal federal policy favoring arbitration agreements, notwithstanding any state substantive or procedural policies to the contrary"). The Court continued:

[Q]uestions of arbitrability must be addressed with a healthy regard for the federal policy

favoring arbitration.... The Arbitration Act established that, as a matter of federal law, any doubts concerning the scope of arbitrable issues should be resolved in favor of arbitration, whether the problem at hand is the construction of the contract language itself or an allegation of waiver, delay, or a like defense to arbitrability.

Id. at 24-25.

168. See id. at 24.

169. 465 U.S. 1 (1984). 
Southland involved a dispute between the convenience store chain 7Eleven and a California franchisee. ${ }^{170}$ The franchise agreement contained a broadly worded arbitration clause, ${ }^{171}$ which the franchisor sought to enforce in order to compel arbitration of the dispute. ${ }^{172}$ The franchisee resisted, citing a portion of the state's franchise law that forbade enforcement of waivers of franchisee rights. ${ }^{173}$ The California Supreme Court reasoned that an arbitration clause was in effect a waiver of the franchisee's right to seek judicial relief in the event of a controversy over the franchise agreement. ${ }^{174}$ The U.S. Supreme Court reversed. ${ }^{175}$

Southland thus presented, in starker relief than Moses $H$. Cone, the issue of whether the Federal Arbitration Act was substantive federal law that took precedence over contrary state law. The Supreme Court could not alter the construction of a state statute declared by the state's highest court, even if it found the reasoning - here, that agreement to arbitration was a sufficient waiver of substantive rights to be forbidden under state franchise law-flawed. ${ }^{176}$ If the decision was to be reversed, it had to be because the state law was powerless against a federal law commanding arbitration ${ }^{177}$-as the Southland Court so found, over the dissents of Justice Stevens ${ }^{178}$ and Justice O'Connor (joined by Justice Rehnquist). ${ }^{179}$

Southland, authored by Chief Justice Burger, who had been promoting alternative dispute resolution from the bully pulpit of the Chief's office, ${ }^{180}$ also appears to mark the beginning of an ideological shift in that Republican and conservative Justices, who might otherwise have opposed broad arbitration clause enforcement on federalism and states' rights grounds, became arbitration advocates notwithstanding the powerful pull these concepts normally exert over Republicans and

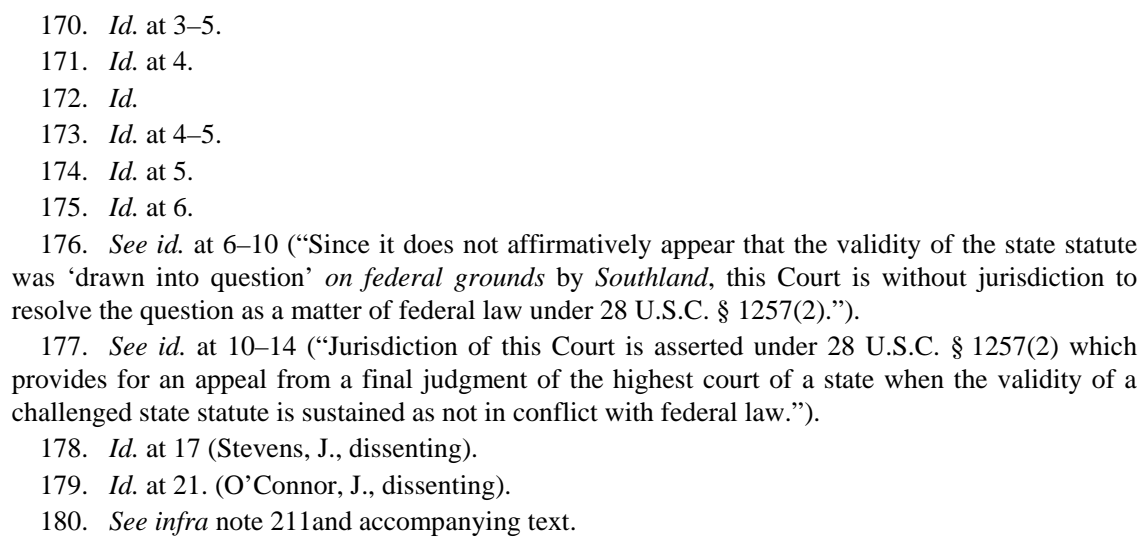
resolve the question as a matter of federal law under 28 U.S.C. § 1257(2).”).

177. See id. at 10-14 (“Jurisdiction of this Court is asserted under 28 U.S.C. § 1257(2) which provides for an appeal from a final judgment of the highest court of a state when the validity of a challenged state statute is sustained as not in conflict with federal law.”).

178. Id. at 17 (Stevens, J., dissenting).

179. Id. at 21. (O’Connor, J., dissenting).

180. See infra note 211and accompanying text. 
conservatives. Justice Rehnquist would soon be largely supportive of outcomes favorable to arbitration. ${ }^{181}$ Although Justice O'Connor continued to express opposition to the nationalization and substantification of the Arbitration Act in Southland, ${ }^{182}$ and was later joined by Justice Thomas, there are today no Republican-appointed Justices opposing arbitrability in close cases. ${ }^{183}$

The Southland majority embraced the modern view of the Act as federal substantive law, relying in part on the statement to that effect in Justice Brennan's Moses $H$. Cone opinion. ${ }^{184}$ Although acknowledging that "the legislative history [of the Act] is not without ambiguities," the Court found that "there are strong indications that Congress had in mind something more than making arbitration agreements enforceable only in the federal courts." 185 The Court further found that "[i]n creating a substantive rule applicable in state as well as federal courts, Congress intended to foreclose state legislative attempts to undercut the enforceability of arbitration agreements." 186 Thus, the Court held "that $\S 31512$ of the California Franchise Investment Law violate[d] the Supremacy Clause” and contained inconsistencies with the Arbitration Act. $^{187}$

Like Moses H. Cone, Southland can be defended as a reasonable decision that does not reflect excessive swooning over arbitration as a forum preferable to court. The text of section 2 of the Act certainly admits of a substantive law construction even if it does not compel the Southland result. The case was a commercial dispute akin to the type of paradigmatic vendor-customer disputes that proponents of the Act had in mind when lobbying for the legislation. ${ }^{188}$ Although franchisees typically are smaller, poorer, and have less leverage than franchisors-at least once the relationship commences-franchisees are usually

181. See, e.g., infra notes 215-22 and accompanying text (discussing Byrd); infra notes 230-42 and accompanying text (discussing Mitsubishi).

182. 465 U.S. at 21-36 (O’Connor, J., dissenting).

183. See infra Part III.D (discussing modern cases in which Republican appointees and conservatives support arbitration generally but oppose class-wide treatment of arbitrable disputes while Democratic appointees and moderates/liberals oppose arbitrability in certain contexts).

184. See 465 U.S. at 14-15; supra text accompanying note 169.

185. 465 U.S. at 12.

186. Id. at 16 (footnotes omitted).

187. Id.

188. See iAN R. MACNEIL, AMERICAN ARbitration LAW: REFORMATIONNATIONALIZATION-INTERNATIONALIZATION 89, 94 (1992) (noting proponents' concerns regarding interstate business contracts). 
competent and often experienced businesspersons or they never would have been awarded the franchise. They are usually not business innocents, and they seldom can credibly claim to be particularly surprised by the presence of an arbitration clause in the franchise agreement given the ubiquity of such clauses in business-to-business contracts throughout the twentieth century. ${ }^{189}$

And unlike consumers signing form receipts before hurrying away from a cash register or continuing to pay bills without reading inserted brochures, franchisees would seem rather certain to have actually read any arbitration clause in the franchise agreement-or at least reasonably can be expected to have actually read the franchise agreement. Becoming a franchisee is a major event in one's working life that logically prompts some study of the terms and conditions insisted upon by the franchisor. To perhaps state the obvious: no one forces a franchisee to become a franchisee. If a franchisor's terms are too unfavorable, the a prospective franchisee continues to have what appears to be the fine option of hanging on to his or her savings, avoiding the risk of a failed franchise, and continuing to work at whatever had provided the prospective franchisee with the funds that made her eligible for a franchise in the first place.

In short, it is difficult to cry very hard for the losing franchisee in a case like Southland, provided that the arbitration forum in which the dispute is heard is a fair one and the procedures available permit adequate factual development of issues involved in the dispute. Southland only required arbitration. ${ }^{190}$ It did not declare that 7-Eleven was certain to win.

Southland can thus be defended as a fair result consistent with the general support for arbitration reflected in the Act and motivated by reasonable public policy concerns in favor of consistency among state and federal courts regarding enforcement of pre-dispute arbitration agreements. Southland may reflect love for arbitration, but this is not the tainted, reckless love the court would later shower upon arbitration. ${ }^{191}$

But neither is Southland a particularly encouraging example of the High Court in action. Although the majority has a plausible textual

189. See, e.g., Edward Wood Dunham, William A. Darrin, Jr. \& Benjamin A. Levin, Franchisor Attempts to Control the Dispute Resolution Forum: Why the Federal Arbitration Act Trumps the New Jersey Supreme Court's Decision in Kubis, 29 RUTGERS L.J. 237, 238 (1998) (noting that "[m]any franchisors use arbitration”).

190. 465 U.S. at 17

191. See supra Part I (discussing the Court's infatuation with arbitration through the years). 
construction of the Act, it can also be argued that the Act's language stating that arbitration agreements may be avoided on "grounds as exist at law or in equity for the revocation of any contract"192 includes illegality under applicable state law such as the California Franchise Investment Act. Although it would not be well articulated for another decade or so, ${ }^{193}$ a natural reading of this statutory language also clearly encompasses state contract law concepts such as fraud, misrepresentation, and unconscionability (both procedural and substantive) that can support setting aside contract terms such as arbitration clauses if the terms are deemed sufficiently oppressive.

The majority has a plausible view of the legislative history. ${ }^{194}$ But Justice O'Connor's dissent is much more thorough in its exploration of legislative history and quite convincing in its argument that the Act was always intended by Congress only to apply to federal court proceedings, which were, at the time, the proceedings with which the commercial proponents of the Act were concerned. ${ }^{195}$ In an important illumination of the result-orientation of the Southland majority, Justice O'Connor notes that Southland is effectively overruling Bernhardt, ${ }^{196}$ which had viewed the Arbitration Act as procedural and thus applied Erie ${ }^{197}$ to require that the validity and enforceability of an arbitration clause litigated in Vermont federal court be decided by Vermont law. ${ }^{198}$ But the Southland majority does not even cite Bernhardt, let alone address it and explain why its reasoning some thirty years earlier-much closer to the time the Arbitration Act was passed-was in error.

This failure suggests that the Southland majority may have been excessively intent on expanding the Act and embracing arbitration on personal preference grounds rather than giving the issue the careful reading of precedent that it deserved. Even if one agrees with the Southland majority that the time had come to consider the Act as

192. 9 U.S.C. $\S 2$ (2006).

193. See Stempel, Bootstrapping and Slouching, supra note 11, at 1385-86 (discussing different ways in which the Federal Arbitration Act has been and can be interpreted).

194. For the majority's discussion of the legislative history of the Federal Arbitration Act, see Southland, 465 U.S. at 12-16.

195. Id. at 25-29 (O’Connor, J., dissenting).

196. See id. at 23 (noting that Bernhardt found "the duty to arbitrate a contract dispute is outcome-determinative... and... governed by state law in federal diversity cases"). For a discussion of Bernhardt v. Polygraphic Co. of American, 350 U.S. 198 (1956), see supra notes 12630 and accompanying text.

197. 304 U.S. 64 (1938).

198. Bernhardt, 350 U.S. at 202-05. 
substantive federal law applicable in state court, the Bernhardt-Erie question at least needed to be addressed. Instead, the Southland majority dodged the issue-another indication of the Court's rush to embrace arbitration notwithstanding the normal rules of adjudication in the face of contrary precedent.

Both Justice O'Connor's dissent and Justice Stevens' concurrence and dissent in Southland make a strong case that the majority's application of the Act is inconsistent with the federalism and states' rights concerns that not only tend to animate U.S. law but also appear to have been on the mind of the enacting Congress. Justice Stevens, in addition to noting Justice O'Connor's compelling review of the legislative history of the Act, focuses on the importance of states' rights and federalism as a strong background norm of statutory interpretation:

The general rule prescribed by $\S 2$ of [the Act] is that arbitration clauses in contracts involving interstate transactions are enforceable as a matter of federal law. That general rule, however, is subject to an exception based on such grounds as exist at law or in equity for the revocation of any contract. I believe that exception leaves room for the implementation of certain substantive state policies that would be undermined by enforcing certain categories of arbitration clauses.

The exercise of State authority in a field traditionally occupied by State law will not be deemed preempted by a federal statute unless that was the clear and manifest purpose of Congress ....

The limited objective of the Federal Arbitration Act was to abrogate the general common law rule against specific enforcement of arbitration agreements.... [B] eyond this conclusion, which seems compelled by the language of $\S 2$ and case law concerning the Act, it is by no means clear that Congress intended entirely to displace state authority in this field.... [W] must be cautious in construing the act lest we excessively encroach on the powers which Congressional policy, if not the Constitution, would reserve to the states ....

... The existence of a federal statute enunciating a substantive federal policy does not necessarily require the inexorable application of a uniform federal rule of decision notwithstanding the differing conditions which may exist in the several States and regardless of the decisions of the States to exert police powers as they deem best for the welfare of their citizens. Indeed, the lower courts generally look to State law regarding questions of formation of the arbitration agreement under $\S 2 \ldots$. .

A contract which is deemed void is surely revocable at law or in equity, and the California Legislature has declared all conditions purporting to waive compliance with the protections of the Franchise Investment 
Law, including but not limited to arbitration provisions, void as a matter of public policy. Given the importance to the State of franchise relationships, the relative disparity in the bargaining positions between the franchisor and the franchisee, and the remedial purpose of the California Act, I believe this declaration of state policy is entitled to respect. $^{199}$

The opinion by Justice Stevens, like much of his judicial work, makes its insights concisely but powerfully and stakes out a moderate position consistent with his overall approach to law. ${ }^{200}$ He respects the text of the statute but does not read it woodenly or hyper-literally. Instead, he reads the text with a healthy reverence for the legislative history of the law that may shed light on specific legislative intent. He is mindful of the purpose of the statute and practical realities of modern commerce and regulation. He respects state prerogatives in an area of traditional state autonomy and the federalist model of U.S. government and law. He is willing to read the Act as laying down substantive law applicable in state as well as federal court, but he gives breathing space to state contract law and regulation. He appreciates that the California franchise law is not an anti-arbitration law but a franchisee protection law, which arguably takes it out of the broad reach of the Act's ${ }^{201}$ compelling of arbitration and puts it into the savings clause of section 2 of the Act.

199. Southland, 465 U.S. at 17-20 (Stevens, J., concurring in part and dissenting in part) (citations omitted) (quoting Metro Indus. Painting Corp. v. Terminal Constr. Co., 287 F.2d 382, 386 (2d Cir. 1961) (Lumbard, C.J., concurring)) (internal quotation marks omitted).

200. See Bill Barnhart \& Gene Schlickman, John Paul Stevens: An Independent Life 200-03 (2010) (discussing Stevens's independent approach to law); Symposium, The Finest Legal Mind: A Symposium in Celebration of Justice John Paul Stevens, 99 GEO. L.J. 1263 (2011). Articles in this symposium noted Justice Stevens's eclectic, flexible, and centrist approach to legal issues that contrasted with more doctrinaire Justices of the left or right. See, e.g., Justin Driver, Judicial Inconsistency as Virtue: The Case of Justice Stevens, 99 GEO. L.J. 1263, 1264 (2011) (discussing different views of Justice Stevens's jurisprudence and tenure on the Court); Jamal Greene, The Rule of Law as a Law of Standards, 99 GEO. L.J. 1289, 1290 (2011) (describing Justice Stevens as "more a justice of standards than a justice of rules"); see also Symposium, The Jurisprudence of Justice Stevens, 74 Fordham L. REV. 1557 (2006); John F. Manning, Competing Presumptions About Statutory Coherence, 74 FORDHAM L. REv. 2009, 2009-10 (2006) (describing Justice Stevens's approach to statutory interpretation).

In his lone dissent in National League of Cities $v$. Usery, in fewer than two pages, Justice Stevens demolishes the majority's concern that wage regulation of local government employees was too much of a federal intrusion on state sovereignty to withstand Tenth Amendment scrutiny. See 426 U.S. 833, 880-81 (1976) (Stevens, J., dissenting). Within a decade, the full Court came to appreciate his wisdom and overruled Usery in Garcia v. San Antonio Metropolitan Transit Authority, 469 U.S. 528, 557 (1985).

201. 9 U.S.C. $\S 2$ (2006). 
Justice Stevens also correctly recognizes, in light of Justice O'Connor's strong arguments based on legislative history, that the Southland majority is engaging in what might be termed "dynamic" or "evolutive" statutory construction ${ }^{202}$ by adapting the 1925 legislation to 1984 commercial reality. Even though he was not persuaded of the applicability of the Act to the California Franchise Investment Act, he noted that “Justice O'Connor's review of the legislative history... demonstrates that the 1925 Congress that enacted the statute viewed the statute as essentially procedural in nature," and he observed that "intervening developments in the law" nonetheless compelled the conclusion reached by the Court-that the Act is substantive law. ${ }^{203}$

The opinion by Justice Stevens in Southland sets a standard by which we can assess the Court's arbitration jurisprudence in the emerging proarbitration or "infatuation" era. Unlike the majority opinion, Justice Stevens' opinion is consistent with mainstream statutory construction, save perhaps that dynamic statutory construction has not been expressly embraced by the legal mainstream, even though the Court sometimes applies it implicitly, as did the Southland majority. ${ }^{204}$

Rightly or wrongly, Southland is an example of dynamic or evolutive statutory construction. The majority expanded the reach of the statute beyond the specific intent of the enacting Congress-and perhaps beyond the basic purpose of the statute as well-although the Southland result can be defended, in part, on broad legislative grounds (i.e., general congressional support for arbitration). But in its sub silentio dynamism, the Southland majority arguably over-reads the text of the Act and minimizes or ignores traditional mainstream concerns of federalism, historical practice, restraint in expanding congressional power absent a clear statement, and deference to traditional state prerogatives.

That the Southland majority was at least partially blinded by love because of its substantive attraction to arbitration seems clear in light of the membership of the Southland majority. Majority opinion author Chief Justice Burger is widely regarded as a jurisprudential conservative, one who would never embrace dynamic or evolutive statutory construction. $^{205}$ Similarly, he was a supporter of states' rights. ${ }^{206}$ One

202. See supra note 108 and accompanying text (discussing the evolutive/dynamic statutory construction approach).

203. Southland, 465 U.S. at 17, 21 (Stevens, J., concurring in part and dissenting in part).

204. See supra note 108 and accompanying text (discussing evolutive approaches to statutory construction).

205. See ABRAHAM, supra note 37, at 239 (reviewing the Burger Court and noting the Chief 
would not have expected Chief Justice Burger to overturn-without so much as a mention or nod-precedent that has stood for thirty years, like Bernhardt, ${ }^{207}$ and to dramatically expand the reach of a federal statute beyond the conceptions of the drafters.

Judge Posner once observed, with perhaps uncomfortable accuracy, that most judicial conservatives tend to be strict constructionists of legislation because they usually wish the statute had not gone so far, while most judicial liberals tend to be "no constructionists" because they wish the statute had gone further. ${ }^{208}$ But where arbitration was concerned, Chief Justice Burger ran counter to this stereotype, as would, in time, the remainder of the Court's conservatives. Southland finds Chief Justice Burger pretending that the legislative history of the Federal Arbitration Act clearly favors compelled arbitration, ${ }^{209}$ an unpersuasive argument even if one likes the outcome in Southland. He similarly reads the text of the law in a manner friendly to the party desiring arbitration ${ }^{210}$ rather than a manner supportive of the State of California, even though the statutory text clearly embraces the use of standard state contract law-and perhaps any state law affecting contracts so long as it is not an unreasonable impediment to federal policy. Under the standard rules of statutory interpretation, California should have received more judicial deference than 7-Eleven. Instead, the Court came to 7-Eleven's rescue, invoking national legislation to steamroll state regulatory efforts-hardly the stuff one expects from a mainstream or conservative Court such as the one sitting during the 1983 Term.

In Southland, Chief Justice Burger was not being true to his professed jurisprudential self. He was, however, being true to his personal preference and public-policy self. Chief Justice Burger had long been a strong supporter of alternative dispute resolution and a strong critic of what he perceived as an unwise litigation explosion. ${ }^{211}$

\footnotetext{
Justice's general conservatism); HALL, supra note 37, at 384-87 (describing Chief Justice Burger as a judicial conservative).

206. See ABraham, supra note 37, at 247 (reviewing the Burger Court and noting the Chief Justice's, and other Justices', general support for state prerogatives); HALL, supra note 37, at 384-87 (describing Chief Justice Burger as supporter of states' authority, particularly in criminal matters).

207. 350 U.S. 198 (1956); see supra notes 126-30 and accompanying text.

208. RICHARD A. POSNER, THE FEDERAL COURTS: CRISIS AND REFORM 293 (1985).

209. See Southland Corp. v. Keating, 465 U.S. 1, 11-14 (1984) (using the Arbitration Act's legislative history to infer that Congress meant for it to have a broad reach).

210. Id.

211. See Jeffrey W. Stempel, New Paradigm, Normal Science, or Crumbling Construct? Trends in Adjudicatory Procedure and Litigation Reform, 59 BROOK. L. REV. 659, 688-705 (1993) (noting
} 
Similarly, one could credibly accuse the other Justices in the majority of inconsistency driven by a personal preference for more arbitration and less litigation, or out of a view that the time, expense, and procedural protection of litigation, including lay jury trials, offers an unfair advantage to deadbeat franchisees or saddles businesses with undue transaction costs in seeking to enforce their franchise agreements.

Joining the Southland majority opinion were Justices Brennan, White, Blackmun, and Powell. ${ }^{212}$ With the exception of Justice Brennan, who espoused support for a "living Constitution" to be interpreted consistently with changes in American society (but who seldom embraced statutory dynamism with equivalent zeal) and who tended to favor federal authority over state authority in many cases, ${ }^{213}$ these Justices were traditionalists who eschewed dynamism for original legislative intent and federalism over unitary control by a central government. $^{214}$ But in Southland they embraced a result seemingly at

the anti-litigation turn taken by legal elites in part as a response to Chief Justice Burger's efforts, including the 1976 Pound Conference, which criticized litigation as wasteful and inefficient, and extolled the virtues of alternative dispute resolution, including arbitration).

212. See 465 U.S. at 1 (Burger, C.J., majority opinion); id. at 17 (Stevens, J., concurring in part, dissenting in part); id. at 21 (O’Connor, J. and Rehnquist, J., dissenting).

213. In Southland, however, Justice Brennan arguably acted inconsistently with his general sympathy for less powerful litigants such as workers, women, racial and ethnic minorities, and small businesspersons. See generally SETH STERn \& STEPHEN WERMIEL, JUSTICE BRENNAN: LiBerAL CHAMPION (2010) (tracing the life, career, and judicial philosophy of Justice Brennan).

214. See ABRAHAM, supra note 37, at 233-34 (reviewing the Burger Court and noting that Justices White, Blackmun, and Powell were generally viewed as moderates, and observing that when Justice Blackmun first joined the Court, his voting was more conservative and closer to that of Chief Justice Burger); HALL, supra note 37, at 368-71, 388-95 (describing Justice White as a moderate and recounting Justice Blackmun's close voting record with Chief Justice Burger); see also LiNDA GREenHOUSE, BECOMing JustiCE BlACKMUN 102-21 (2005) (noting Justice Blackmun's general drift toward more liberal stances during the latter half of his time on the Court).

Both Justices Blackmun and Powell arguably were selected for the Court because of their moderation. Prior to their emergence as candidates for the Court, President Nixon had nominated G. Harrold Carswell and Clement Haynsworth to open seats, only to have both run into confirmation problems. ABRAHAM, supra note 37, at 10-13. Nixon needed to submit new names of candidates who would not have the arguable problems of competence-Carswell-or conflict of interestHaynsworth-(although the allegations against Haynsworth, a respected Fourth Circuit judge, are not, in the wisdom of hindsight, considered unfair by most observers) as well as having sufficient centrist tendencies that Democrats would not fight as too conservative. Id. Justice Powell, a former ABA president, and Justice Blackmun, a long-time Eighth Circuit judge and former counsel to the Mayo Clinic, both fit the bill as impeccable mainstream candidates for the Court. HALL, supra note 37, at 389, 393; ABRAHAM, supra note 37, 13-15 (describing President Nixon's appointments of Justices Blackmun and Powell to the Supreme Court). For other descriptions of President Nixon's appointment process, see LeE EpSTEIN \& JOSEPH F. KOBYLKA, THE SUPREME COURT \& LEGAL Change: Abortion \& THe Death Penalty 16-17 (1992); Richard Nixon, RN: THE MEMOIRS of Richard NiXon 415, 420-24 (1978); Richard ReEVEs, President NiXon: Alone in the WHITE HOUSE 126, 132, 134, 151-52, 164, 185-86 (2001); CHRISTOPHER L. TOMLINS, THE UNITED 
odds with their professed jurisprudential philosophies. The logical catalyst for this departure from their traditional moorings in Southland was a substantive preference for arbitration, even if this group was not overtly cheerleading for alternative dispute resolution and decrying litigation.

In Dean Witter Reynolds, Inc. v. Byrd, decided in 1985, the year after Southland, the Court continued in a pro-arbitration vein, but a defensible one. ${ }^{215}$ The issue was whether a customer's mixture of federal securities claims - not arbitrable because of Wilko ${ }^{216}$-and state law claimsclearly arbitrable by themselves under the Act-prevented arbitration of the state claims because they were intertwined with the non-arbitrable federal claim. ${ }^{217}$ Resolving a split in the circuits, the Court rejected the intertwinement doctrine that had required all claims to go to litigation and held that arbitration of the state law claims could be compelled and need not await resolution of the securities claims. ${ }^{218}$ The Court recognized that there could be preclusion issues, depending on which adjudication took place first, but it did not attempt to provide guidance on that issue. ${ }^{219}$ The Byrd decision was unanimous, ${ }^{220}$ a reflection of its reasonableness under the circumstances - the Court was saddled with the Wilko precedent that was steadily falling out of fashion. The Byrd opinion supports more arbitration rather than less, but it can hardly be viewed as unduly colored by personal preferences for arbitration.

Concurring separately, Justice White, a member of the Moses $H$. Cone and Southland majorities, and a consistent supporter of arbitration during his time on the Court, criticized Wilko, noting that the holding involved only claims under the Securities Act of 1933 and that courts cannot assume the same reasoning applies to claims brought under the Securities Exchange Act of 1934. ${ }^{221}$ Justice White argued that there were sufficient differences between the laws such that Wilko's restriction on

States Supreme Court: The Pursuit of Justice 303 (2005); Michael A. Genovese, Richard M. Nixon and the Politicization of Justice, in WATERgATE AND AFTERWARD: THE LEGACY OF RICHARD M. NIXON 79 (1992).

215. 470 U.S. 213 (1985)

216. 346 U.S. 427 (1953), overruled by Rodriguez de Quijas v. Shearson/Am. Express, Inc., 490

U.S. 477 (1989); see supra notes 125 and accompanying text (discussing the holding in Wilko).

217. Byrd, 470 U.S. at 214

218. Id. at 223-24.

219. Id. at 221-24.

220. Id. at 213.

221. Id. at 224-25 (White, J., concurring). 
arbitration should be confined strictly to claims under the 1933 Act. $^{222}$ Although Justice White's attempt to differentiate the statutes is not particularly persuasive, it is an important small step toward overruling Wilko — and its shaky reasoning based on the 1933 Act and the Burger Court majority's personal public-policy preferences-and removing statutory restrictions on arbitration.

In Mitsubishi Motors Corp. v. Soler Chrysler-Plymouth, Inc., the Court again supported arbitration, dealing an implicit blow to cases like Wilko, Alexander, Barrentine, and McDonald that had restricted arbitration for statutory claims. ${ }^{223}$ The Court found no legal barrier to requiring arbitration of antitrust claims raised by an automobile retailer in its dispute with the manufacturer. ${ }^{224}$ The contract between the retailer and the manufacturer, as might be expected in this commercial setting, contained a broadly worded arbitration clause. ${ }^{225}$

Writing for the majority, Justice Blackmun found no basis in statutory text, legislative intent or purpose, or public policy for cutting back the scope of the arbitration agreement merely because one of the bases of dispute involved a federal statute. ${ }^{226}$ In reaching this result, the Court sounded more loudly the death knell of Wilko and similar cases that opposed arbitration of certain claims based on public policy grounds. "[W]e find no warrant in the Arbitration Act for implying in every contract within its ken a presumption against arbitration of statutory claims," wrote Justice Blackmun. ${ }^{227}$ The majority opinion reiterated much of the pro-arbitration rhetoric of Moses H. Cone, Southland, and Prima Paint about the strong federal policy favoring arbitration. ${ }^{228}$

Lost in some of the rhetoric was the better interpretation that Congress intended to mandate enforcement of validly made arbitration agreements more than it was making a general endorsement of arbitration under all circumstances. But the arbitration clause at issue between these

222. Id.

223. 473 U.S. 614, 640 (1985); see supra notes 125-26 and accompanying text (discussing Wilko and Barrentine); supra notes 155-58 and accompanying text (discussing Alexander); supra notes 160-61 and accompanying text (discussing McDonald).

224. Mitsubishi, 473 U.S. at 640.

225. See id. at 617 (discussing the terms of the sales contract).

226. Id. at $636-40$.

227. Id. at 625 .

228. Id. at 625-26 (analyzing Moses H. Cone, Southland, and Prima Point); see supra notes 142-43 and accompanying text (discussing Prima Paint); supra notes 162-69 and accompanying text (discussing Moses H. Cone), supra notes 169-214 and accompanying text (discussing Southland). 
merchants did not raise serious issues of consent, construction, fraud, coercion, or other bases for setting aside the agreement. ${ }^{229}$ The party resisting arbitration hoped that the Court, like some lower courts, would find antitrust law too sacred to be submitted to arbitrators, even at the request of the parties.

Mitsubishi can thus be seen as part of the arbitration trend of the 1980s, but not a case where the Court is unduly infatuated with arbitration. Certainly, the entire Court was not infatuated. ${ }^{230}$ The Court's rejection of a statutory claim defense to arbitration was rejected by only a 5-3 majority. ${ }^{231}$ At this juncture, one can argue it is the dissenters who are unfaithful to their normal jurisprudential approaches of applying the statute as written with appreciation of legislative intent, congressional purpose, and the norms of contract formation and enforcement.

In dissent, Justice Brennan, the author of Moses H. Cone and part of the Southland majority, suddenly positioned himself against arbitration merely because the case involved an antitrust claim. ${ }^{232}$ Despite dissenting here, Justice Marshall had also been part of the Moses $H$. Cone and Southland majorities. Justice Stevens' dissent was arguably inconsistent with his prior positions as well, but the issues in Southland are distinct from the statutory exception question presented in Mitsubishi and prior cases such as Wilko, Alexander, Barrentine, and McDonald. But Justice Stevens is also arguably consistent in his respect for stare decisis. ${ }^{233}$ He often took the position that precedents, even precedents he viewed as incorrect at the time decided, should be respected going forward, absent very strong intervening events counseling overruling. ${ }^{234}$

229. See Mitsubishi, 473 U.S. at 617.

230. Id. at 640 (Stevens, J., Brennan, J., and Marshall, J., dissenting). Justice Powell did not participate in the decision. Id.

231. Id. at 614 (majority opinion).

232. See id. at 640 (Stevens, J., Brenan, J., and Marshall, J., dissenting).

233. See id. at 650 (concluding that because the Court has repeatedly recognized the distinction between federal statutory rights and contract rights and that arbitration has been used almost entirely in labor and commercial disputes, a presumption exists that arbitration clauses do not apply to federal statutory claims).

234. See, e.g., Quill Corp. v. North Dakota, 504 U.S. 298, 311 (1992) (adhering to precedent even though "contemporary ... jurisprudence might not dictate the same result were the issue to arise for the first time today”); Square D Co. v. Niagara Frontier Tariff Bureau, Inc., 476 U.S. 409, 420, 423-24 (1986) (refusing to reject settled Court precedent even assuming the decision "was unwise as a matter of [public] policy" and that its reasoning had been undermined by subsequent procedural and judicial developments, as these developments "are insufficient to overcome the strong presumption of continued validity that adheres in the judicial interpretation of a statute"). 
His dissent can be defended as merely seeking to treat antitrust claims the same as 1933 Securities Act claims (and perhaps 1934 Act claims as well), Title VII claims, Fair Labor Standards Act Claims (FLSA), and 42 U.S.C. § 1983 claims - all of which had been exempted to a degree from arbitration in the Court's prior decisions. ${ }^{235}$ At this juncture, Justice Stevens was willing to embrace the statutory exception perhaps as much for its pedigree as for its rationale. ${ }^{236}$

But Justice Stevens in his Mitsubishi dissent appears to be more than just a reluctant follower of precedent. ${ }^{237}$ He seems to enthusiastically embrace the notion that there is something different about statutory claims that makes them unsuitable for arbitration — or at least outside the intended scope of the Arbitration Act. ${ }^{238}$ Justice Stevens, whose Southland dissent was so persuasive, had a tough position to defend in Mitsubishi, where the dissent is considerably less convincing. The text of the Arbitration Act contains no restraint on statutory claims. ${ }^{239}$ The legislative history reflects no congressional aversion to arbitration of such claims. ${ }^{240}$ The purpose and background of the statute, although contract-focused and praising commercial actor expertise, do not suggest that Congress viewed arbitrators as incompetent on statutory claims. ${ }^{241}$ Pragmatically, it would also appear odd and inefficient to separate antitrust claims from the rest of a dispute that arbitrators must hear in any event. But whatever one's views on the merits, the case, while proarbitration, does not reflect unbridled infatuation with arbitration. ${ }^{242}$

235. See Mitsubishi, 473 U.S. at 647-50 (Stevens, J., Brenan, J., and Marshall, J., dissenting) (noting that the Court has not allowed arbitration under the 1933 and 1934 Securities Acts, Title VII, FLSA, and § 1983).

236. C.f. Burnham v. Superior Court, 495 U.S. 604, 621 (1990) (Scalia, J., plurality opinion) (asserting that service of process on a nonresident defendant who is physically in the forum state at the time of service satisfies due process because of longstanding custom and that for service conferring personal jurisdiction its "validation is its pedigree").

237. See supra note 234 and accompanying text.

238. See Mitsubishi, 473 U.S. at 650-57 (Stevens, J., Brenan, J., and Marshall, J., dissenting) (describing the unique nature of the antitrust statutes).

239. See supra Part II.A.

240. See supra note 194; see also 1 IAN R. MACNEIL, Richard E. SPEIDEL \& THOMAS J.

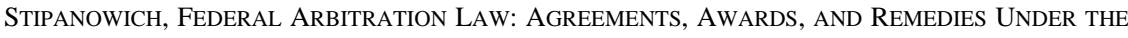
FEDERAL ARBITRATION ACT §§ 8:1-8:2 (1994) (discussing the Arbitration Act’s legislative history). 241. Id.

242. AT\&T Technologies, Inc. v. Communication Workers of America is a bit of driftwood on the generally rising tide of arbitration. 475 U.S. 643 (1986). Although continuing to give rhetorical support to arbitration, the Court finds that the instant labor-management dispute does not fall within the scope of what appears to be a very broadly worded arbitration clause-at least it did not fall within the confines of Prima Paint, which requires that questions regarding defenses to the contract are in the first instance for the arbitrator. Id. at 651-52. Instead, the Court found that the trial court 
Two Terms later, the Court advanced the cause of arbitrability and sounded the death knell of Wilko in Shearson/American Express, Inc. v. McMahon. ${ }^{243}$ Picking up on Justice White's concurrence in Byrd, ${ }^{244}$ the Court refused to extend the securities law statutory exception from Wilko to claims made pursuant to the Securities Exchange Act of 1934, holding the agreement to arbitrate enforceable under the Federal Arbitration Act. ${ }^{245}$ Although the 1933 Act exception from Wilko was not dead yet, it was living on borrowed time in that the rationale for refusing a statutory claim exception in McMahon is equally applicable to and powerful regarding 1933 Act claims that were at issue in Wilko. ${ }^{246}$ The McMahon Court also rejected the argument that claims made pursuant to the Racketeer Influenced and Corrupt Organizations Act (RICO) were exempt from arbitration, a view shared by the entire Court, that also runs counter to the notion of the existence of a statutory claims or public policy exception to arbitrability. ${ }^{247}$

McMahon was thus an important pro-arbitration opinion in the sense that it set the stage for further curtailment of the statutory claims exception to arbitrability. Symbolically, Justice O'Connor, who dissented so strongly in Southland, wrote the McMahon majority opinion. To be fair, her view in McMahon is not inconsistent with her Southland view that the Act applies only in federal court proceedings because McMahon was federal court litigation. But her emerging enthusiasm for arbitration at least looks a little odd when compared to her resistance to it just three years earlier.

Justice Blackmun, as joined by Justices Brennan and Marshall, dissented, arguing that the 1934 Act was sufficiently similar to the 1933 Act such that the McMahon claim should enjoy the protection against arbitrability provided by Wilko. ${ }^{248}$ Scoring some points in opposition to

that should initially assess the scope of the arbitration clause in the collective bargaining agreement at issue. Id. at 652. The Court was unanimous, with Justice White authoring the majority opinion, id. at 645, and Justice Brennan concurring in an opinion joined by Chief Justice Burger and Justice Marshall. Id. at 652 (Brennan, J., concurring)..

243. 482 U.S. 220 (1987).

244. 470 U.S. 213 (1985); see supra notes 215-22 and accompanying text.

245. 482 U.S. at 238.

246. See Stempel, supra note 104, at 294 (likening Wilko's status to that of a "wounded animal limping across the Savannah," sure to be attacked again after McMahon's undercut its rationale).

247. 482 U.S. at 238-42 (concluding that an arbitral forum would not adequately vindicate RICO claims and that enforcement of the arbitration clause did not constitute a waiver of substantive rights under the statute).

248. See 482 U.S. at 243. 
arbitration, the dissent noted that in 1975 Congress made extensive amendments to the 1934 Act and it appeared from the legislative history that "Congress did not want the amendments to overrule Wilko" and that "[legislative history of] an amendment to the Exchange Act suggests that Congress was aware of [and approved] the extension of Wilko to § 10(b) claims [made under the 1934 Act]."249

Although on the losing side of this significant battle, the dissenters fought hard against the constriction and foreshadowed demise of Wilko. The dissenting opinion is longer than the majority opinion. ${ }^{250}$ But the decision has some reasonable jurisprudential support in seeking to treat all claims as equal for purposes of arbitrability. ${ }^{251}$ The decision is not so much one enamored of arbitration as it is a reflection of the absence of fear that arbitration might be too inferior a process for resolving statutory claims. The Court is not hostile to arbitration, but neither is it in arbitration's thrall.

The same year, in Perry v. Thomas, the Court struck another blow for arbitration. In an opinion by Justice Marshall, it compelled arbitration of a wage claim in the face of a state law exempting wage claims from arbitration. ${ }^{252}$ In effect, Merrill Lynch, Pierce, Fenner \& Smith, Inc. v. Ware ${ }^{253}$ was overruled while Southland ${ }^{254}$ was affirmed, shoring up the strength of the pro-arbitration working majority of the Court just four years after the watershed Southland decision. Perry continued the Court's embrace of arbitration on the rhetorical level as well as making substantial citation to the Court's recent pro-arbitration decisions. ${ }^{255}$ The message to even the casual reader is pretty clear: arbitration is generally strongly supported by the Court, even in the face of contrary state law.

Perry is generally susceptible to the same bases of praise or scorn one might heap on Southland. The majority, with Justices Marshall, Burger, Blackmun, Brennan, and White, purports to embrace mainstream jurisprudence but arguably neglects to consider core mainstream judicial concerns of federalism, state prerogatives of contract regulation, and

\footnotetext{
249. Id. at 247 (Blackmun, J., concurring in part and dissenting in part).

250. Compare id. at 222-42 (majority opinion), with id. at 247-68 (Blackmun, J., concurring in part and dissenting in part).

251. See id. at 226 (majority opinion).

252. 482 U.S. 483, 490-91 (1987).

253. 414 U.S. 117 (1973); see supra text accompanying notes 146-51.

254. 465 U.S. 1 (1984); see supra text accompanying notes 169-214.

255. See Perry, 482 U.S. at 489-91.
} 
legislative intent and purpose, and it reads the Arbitration Act's text too broadly. ${ }^{256}$ But Perry may be better defended than Southland in that the California Labor Code $\S 229$ at issue in Perry appears more directly aimed at arbitration ${ }^{257}$ and, thus, is in conflict with the now-deemedsubstantive federal law, while the California Franchise Investment Act at issue in Southland was a broader prohibition against waivers of all types, not solely arbitration clauses. ${ }^{258}$ Only Justices Stevens and O’Connor dissented, each in separate opinions. ${ }^{259}$ Justice O’Connor reiterated her view that the enacting Congress did not intend the Arbitration Act to create substantive federal law applicable to state proceedings and echoed Justice Stevens' view from Southland that the Act's own language permits refusal to order arbitration if there were other bases under state law preventing enforcement of the contract. ${ }^{260}$

Justice Stevens made a similar argument based on legislative intent and purpose, and he defended an originalist notion of statutory interpretation even though his Southland dissent had been relatively dynamic in its approach to the statute. ${ }^{261}$

Even though the Arbitration Act had been on the books for almost 50 years in 1973, apparently neither the Court nor the litigants even considered the possibility that the Act had pre-empted state-created rights. It is only in the last few years that the Court has effectively rewritten the statute to give it a pre-emptive scope that Congress certainly did not intend. ${ }^{262}$

Whatever the merits of the pro- and anti-arbitration perspectives clashing in Perry, it seems odd that the majority did so little to defend its position against the contention that it had been unfaithful to the legislative intent and purpose of the law as well as the rights of the sovereign states to regulate contractual undertakings. In essence, the

256. See Larry J. Pittman, The Federal Arbitration Act: The Supreme Court's Erroneous Statutory Interpretation, Stare Decisis, and a Proposal For Change, 53 ALA. L. REV. 789, 874-75 (2002).

257. See CAL. LAB. CODE ANN. § 229 (West 2011) (specifically stating that actions for payment of wages may be maintained "without regard to the existence of any private agreement to arbitrate").

258. See supra note 173 and accompanying text.

259. Perry, 482 U.S. at 493-96 (Stevens, J. and O’Connor, J., dissenting).

260. See id. at 493 (O’Connor, J., dissenting).

261. Id. at 493-94 (Stevens, J., dissenting); see supra text accompanying note 200.

262. 482 U.S. at 493 (Stevens, J., dissenting) (citing to his Southland dissent and also contending that "the States' power to except certain categories of disputes from arbitration should be preserved unless Congress decides otherwise"). 
Perry majority rests on the analysis of Southland, which makes Perry subject to the same criticisms and the same concern that enthusiasm for arbitration has overwhelmed the Court's ordinary concern about the intent and goals of the enacting Congress and protection of the states.

In what could be regarded as a retreat from its ordinary preference for arbitration, the Court in Volt Information Sciences, Inc. v. Board of Trustees of the Leland Stanford Junior University held that where a contract containing an arbitration clause also selects specific state law as applicable to the dispute, the state's law regulating arbitration agreements supplants the Federal Arbitration Act. ${ }^{263}$ In this case, that meant that California state law restrictions on arbitration were not preempted by the Federal Arbitration Act and could prohibit enforcement of an arbitration agreement that was otherwise enforceable under federal law. ${ }^{264}$ The decision prompted the ire of Justice Brennan, who dissented with Justice Marshall and contended that the ruling was a threat to the overall enforceability of the federal law. ${ }^{265}$ The dissent's argument is that most of the same contracts that contain arbitration clauses contain choice-of-law clauses as well. ${ }^{266}$ Consequently, the dissent saw the decision as a threat to the enforcement of a host of arbitration agreements, seeming to overlook that contract drafters could easily write their way around any potential problems by providing that federal law controlled questions of arbitrability. Although the dissent may be consistent with Justice Brennan's generally pro-arbitration views, it seems inconsistent with dissents in other cases. In any event, Volt as a whole suggests some limits on the Court's arbitral infatuation of the 1980s.

In Rodriguez de Quijas v. Shearson American/Express, Inc., the Court completed the process begun in Byrd and McMahon and formally overruled Wilko. ${ }^{267}$ The Court had now eliminated the rationale for recognizing a statutory claims exception to arbitration as well as for making 1933 Act claims subject to arbitration. ${ }^{268}$ Although the arbitral exceptions for Title VII, FLSA, and § 1983 claims in prior case law were not overturned, they appeared to be in jeopardy.

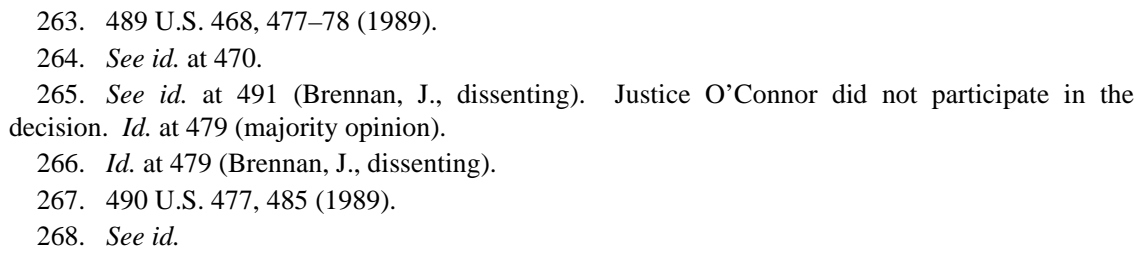


But in Gilmer v. Interstate/Johnson Lane Corp., the Court reaffirmed its apparently continuing commitment to these public policy exceptions to arbitrability by distinguishing them from Age Discrimination in Employment Act (ADEA) claims, for which the Court found no such exception. ${ }^{269}$ Notwithstanding the arguable support for exceptions from arbitration for Title VII, FLSA, and $\S 1983$ claims, arbitral infatuation is dramatically present and ascendant in Gilmer. ${ }^{270}$ The case involved a securities industry employee making an ADEA claim against the brokerage house that fired him at age sixty-two. ${ }^{271}$ The Gilmer majority, in an opinion by Justice White, treats the case as simply one of whether a statutory exception exists for ADEA claims and determines the answer is “no," as per Rodriguez, McMahon, and Mitsubishi. ${ }^{272}$

The Court gave only glancing attention, in part because the issue was raised late in the proceedings by Gilmer's amici, ${ }^{273}$ to a much stronger argument contending that the Act itself, in its clear text, states that arbitration clauses in employment contracts are not enforceable, at least for workers engaged in interstate commerce. ${ }^{274}$

Rather than simply refusing to consider the section 1 argument because of waiver, the Gilmer majority used a bit of linguistic sleight of hand to avoid the issue:

In any event, it would be inappropriate to address the scope of the $\S 1$ exclusion because the arbitration clause being enforced here is not contained in a contract of employment. The FAA requires that the arbitration clause being enforced be in writing. The record before us does not show, and the parties do not contend, that Gilmer's

269. 500 U.S. 20, 33-35 (1991).

270. E.g., id. at 30 ("[G]eneralized attacks on arbitration ... are 'far out of step with our current strong endorsement of the federal statutes favoring [arbitration].”' (quoting Rodriguez de Quijas, 490 U.S. at 481)).

271. Id. at 23.

272. Id. at 23, 26.

273. See id. at 24 n.2 ("Several amici curiae in support of Gilmer argue that [section 1 of the Act] excludes from the coverage of the FAA all 'contracts of employment.' Gilmer, however, did not raise the issue in the courts below, it was not addressed there, and it was not among the questions presented in the petition for certiorari.").

274. See 9 U.S.C. § 1 (2008) (“[N]othing herein contained [in the Act] shall apply to contracts of employment of seamen, railroad employees, or any other class of workers engaged in foreign or interstate commerce.”). Although an individual worker may be engaged in interstate commerce, he or she might not be part of a class of workers regularly engaged in such commerce. Gilmer, however, as a stock broker, surely fell within a common-sense meaning of the words of section 1 in that securities brokers, dealers, agents, and sales and servicing employees most certainly are as a group engaged in interstate commerce because of the nature of financial markets and the common use of wire, mail, and telephone communications as part of their activities. 
employment agreement with Interstate contained a written arbitration clause. Rather, the arbitration clause at issue is in Gilmer's securities registration application, which is a contract with the securities exchanges, not with Interstate. The lower courts addressing the issue uniformly have concluded that the exclusionary clause in $\S 1$ of the FAA is inapplicable to arbitration clauses contained in such registration applications.... Unlike the dissent, we choose to follow the plain language of the FAA and the weight of authority, and we therefore hold that $\S 1$ 's exclusionary clause does not apply to Gilmer's arbitration agreement. Consequently, we leave for another day the issue raised by amici curiae. $^{275}$

The Gilmer majority's dismissive language begs the question of how an arbitration clause can be sufficiently subject to the Act to be enforceable by the employer if it is not contained in a contract between the employer and employee. The success of the securities industry in requiring that all its licensed brokers sign arbitration agreements would logically make out a stronger case for extending section 1 protections to those workers, who clearly must submit to the arbitration clause as a condition of employment and where there is no reasonable alternative. ${ }^{276}$ Instead, the Gilmer Court defined the problem away through a legal fiction.

In dissent, Justice Stevens, who raised troubling objections to the Court's embrace of arbitration rather than federalism or legislative history in Southland, ${ }^{277}$ offered a rather devastating rebuttal. ${ }^{278} \mathrm{He}$ pointed out that the Court on many occasions has not strictly enforced the concept of waiver in order to render a full assessment of a case before it. ${ }^{279}$ He then noted the narrowness of the Court's concept of what constitutes a "contract of employment:"

275. Gilmer, 500 U.S. at 24 n.2 (citations omitted). "Another day" came a decade later when the Court decided Circuit City. 532 U.S. 105, 109 (2001) (holding that even where the arbitration agreement was in a direct contract between employer and employee asserting a Title VII claim, section 1's exclusion was inapplicable because the employee, a retail electronics salesperson and manager, was not part of a class of workers engaged in interstate commerce); see infra notes 320-28 and accompanying text.

276. See id. at 23 (noting that Gilmer was required by his employer to register with several stock exchanges, his uniform application for registration provided for arbitration, and the New York Stock Exchange has a rule providing for arbitration for registered representatives).

277. See Southland Corp. v. Keating, 465 U.S. 1, 21 (1984) (Stevens, J., dissenting) (finding "no evidence" that Congress intended to treat a state's definition of "invalid as contrary to public policy" differently than the federal government's with respect to the enforceability of an arbitration agreement).

278. See Gilmer, 500 U.S. at 36-43 (Stevens, J., dissenting).

279. See id. at 37. 
Given that the FAA specifically was intended to exclude arbitration agreements between employees and employers, I see no reason to limit this exclusion from coverage to arbitration clauses contained in agreements entitled "Contract of Employment." In this case, the parties conceded at oral argument that Gilmer had no "contract of employment" as such with respondent. Gilmer was, however, required as a condition of his employment to become a registered representative of several stock exchanges, including the New York Stock Exchange (NYSE) Just because his agreement to arbitrate any "dispute, claim or controversy" with his employer that arose out of the employment relationship was contained in his application for registration before the NYSE rather than in a specific contract of employment with his employer, I do not think that Gilmer can be compelled pursuant to the FAA to arbitrate his employment-related dispute. Rather, in my opinion the exclusion in $\S 1$ should be interpreted to cover any agreements by the employee to arbitrate disputes with the employer arising out of the employment relationship, particularly where such agreements to arbitrate are conditions of employment. ${ }^{280}$

On the issue of the meaning of section 1, Justice Stevens marshals equally compelling evidence of legislative intent to protect vulnerable workers from unwanted arbitration agreements when they are seeking work. ${ }^{281}$ Although the legislative history focused on workers who were constantly and visibly involved in physical movement across state lines, this was a mere consequence of the involvement of the Seaman's Union during the legislative process, which understandably used seamen as their paradigmatic example of workers who should not be unfairly saddled with nonconsensual arbitration agreements. ${ }^{282}$

Although the discussion of the employment exception in Gilmer is necessarily truncated, it foreshadows the Court's ultimate unfortunate, crabbed reading of section 1 in Circuit City, Inc. v. Adams. ${ }^{283}$ In taking a narrow view of section 1, the Court downplayed the text of the Act, congressional intent, statutory purpose, and the federalism concerns of the states in protecting workers from potentially unfair tribunals that

280. Id. at 40. Justice Stevens then marshaled history and precedent supporting a broad reading of the term "contract of employment" with respect to the Act. Id. at 40-41 (noting that collectivebargaining agreements have fit into the section 1 exclusion).

281. See id. at 41-42.

282. See Jeffrey W. Stempel, Reconsidering the Employment Contract Exclusion in Section 1 of the Federal Arbitration Act: Correcting the Judiciary's Failure of Statutory Vision, 1991 J. DIsP. RESOL. 259, 263-64 (reviewing the origin of the statutory provision and case law and arguing for a construction of section 1 applicable to all workers involved in interstate commerce, rather than the narrow railroad-trucker-seaman-only construction provided by some courts).

283. 532 U.S. 105, 119 (2001); see infra notes 320-28 and accompanying text. 
might be imposed upon the workers without their consent due to the great leverage held by employers. ${ }^{284}$

There is of course a jurisprudential inconsistency in the Court's broad and aggressive reading of section 2 of the Act regarding the enforceability of arbitration coupled with the Court's very narrow reading of section 1 of the Act protecting employees from compelled arbitration. Logically, section 1 should receive the same interpretative treatment as does section 2. Given the legislative intent and statutory purpose of enforcing commercial arbitration agreements between merchants and halting judicial reluctance to specifically enforce clearly consensual arbitration clauses, there is nothing inconsistent with a proarbitration view of the Act that also recognizes that the Act does not extend its support of arbitration to the employment context.

Despite the tangential treatment of section 1 in Gilmer, the decision, with only Justices Stevens and Marshall in dissent, suggests a Court becoming more committed to arbitration as a process and willing to depart from standard statutory construction to support this favored process. Ironically, however, the same Court that was moving toward a narrow view of section 1 and the degree of interstate activity required to protect workers from unwanted pre-dispute arbitration clauses took a broad view of interstate commerce regarding the reach of the Act generally in its next case.

In a divided opinion in Allied-Bruce Terminex Companies, Inc. v. Dobson, the Court held that the Arbitration Act reaches as broadly as the limits of congressional power under the Commerce Clause. ${ }^{285}$ The division of the Court revolves around more technical issues of language and procedure rather than basic orientation toward the Act. ${ }^{286}$ The decision supports arbitration but was hardly a shocking break with expectations, at least in light of the fact that the Act had been considered substantive law for ten years since Southland and that the Court had given a broad construction to the concept of interstate commerce at least since the New Deal. ${ }^{287}$ Dobson continued the Court's support for

284. See id. at 109 ("[T] he better interpretation is to construe the statute... to confine the exemption to transportation workers.”).

285. 513 U.S. 265, 268 (1995).

286. The concurring opinion of Justice O'Connor and the dissenting opinions of Justices Scalia and Thomas argue that the Act should not apply in state courts; they do not argue against the breadth of section 2. See id. at 282-84 (O’Connor, J., concurring); id. at 284-85 (Scalia, J., dissenting); id. at 285-97 (Thomas, J., dissenting).

287. See, e.g., NLRB v. Jones \& Laughlin Steel Corp., 301 U.S. 1, 37 (1937) (holding Congress 
arbitration but is a defensible decision that simply looks bad when juxtaposed with the Court's unwillingness to give pro-employee section 1 the same treatment accorded the Act generally.

Nonetheless, Justices Scalia and Thomas were moved to dissent (at length in the case of Justice Thomas), arguing that Southland was wrongly decided. $^{288}$ By this juncture, however, Justice O'Connor appeared to have thrown in the towel. ${ }^{289}$ She still thought Southland was wrongly decided but acknowledged its precedential authority and concurred in the Dobson decision. ${ }^{290}$

As discussed below, Dodson was hardly the end of the Court's "effort to expand the Federal Arbitration Act." 291 That would await Justice O'Connor's retirement and the personnel changes of the Roberts Court, which produced more infatuatedly and dramatically divisive proarbitration opinions restricting class action litigation and even class action arbitration. ${ }^{292}$

During the same year Dodson was decided, the Court in Mastrobuono v. Shearson Lehman Hutton, Inc., refused to limit the arbitrator's authority to award punitive damages in a case that turned largely on choice-of-law principles and the peculiar New York rule that punitive damages could not be awarded in arbitration. ${ }^{293}$ The decision is pro-arbitration in that it favors greater remedial powers for arbitrators, although that would not have been the case had the agreement in question properly imported New York substantive law. But the decision is also pro-consumer in that it provides the prospect of greater remedies in the arbitrations into which more and more matters are being funneled. $^{294}$

On the whole, Mastrobuono is not a moment when the Court's infatuation with arbitration is on display-the case is resolved on more technocratic grounds. ${ }^{295}$ The uncontroversial nature of the ruling is

\footnotetext{
has the power to control activities that have a "close and substantial relation to interstate commerce").

288. See Dobson, 513 U.S. at 284 (Scalia, J., dissenting) ("I agree with respondents ... that Southland clearly misconstrued the Federal Arbitration Act.”); id. at 285 (Thomas, J., dissenting) ("In my view, [stare decisis] is insufficient to save Southland.").

289. See id. at 283-84 (O’Connor, J., dissenting).

290. Id.

291. Id.

292. See infra Part III.D.

293. 514 U.S. 52, 56 (1995).

294. See id. at 61-64.

295. The Court based its decision on common law rules for contract interpretation, not on public
} 
reflected in the 8-1 vote of the Court, with Justice Thomas dissenting on the ground that the choice-of-law provision at issue in the case is not materially different than the one in Volt, which required application of California law at odds with the federal common law of arbitration. ${ }^{296}$ Justice Thomas saw the New York law sought by the brokerage house as insufficiently different to avoid the reach of New York's prohibition on punitive damages in arbitration. ${ }^{297}$

In another 1995 decision, the Court in First Options of Chicago, Inc. $v$. Kaplan, reaffirmed the general rule that, notwithstanding the federal policy favoring arbitration, the question of whether an agreement requires arbitration is for the courts and not the arbitrator. ${ }^{298}$ By contrast, general questions going to the contract as a whole are initially for the arbitrators as provided in Prima Paint and its progeny. ${ }^{299}$ The actual decision-making in such cases turns on whether a party resisting arbitration has a challenge to the arbitration agreement itself or merely a defense to the contract as a whole or some portion of the contract other than the arbitration clause. ${ }^{300}$ The Court held that "because the Kaplans did not clearly agree to submit the question of arbitrability to arbitration, the Court of Appeals was correct in finding that the arbitrability of the dispute was subject to independent review by the courts." ${ }^{301}$ Regarding standards of review, the First Options Court unanimously held that:

[T] here is no special standard governing [appellate] review of a district court's decision [to confirm or vacate an arbitration award]. Rather, review of, for example, a district court decision confirming an arbitration award on the ground that the parties agreed to submit their dispute to arbitration, should proceed like review of any other district court decision finding an agreement between parties, e.g., accepting findings of fact that are not "clearly erroneous" but deciding questions of law de novo. ${ }^{302}$

policy rationales supporting arbitration. Id. at 62 .

296. See Volt Info. Sci., Inc. v. Bd. of Trs. of the Leland Stanford Junior Univ., 489 U.S. 468, 470 (1989); see supra notes 263-66 and accompanying text (discussing Volt).

297. See Mastrobuono, 514 U.S. at 64 (Thomas, J., dissenting); see also Garrity v. Lyle Stuart, Inc., 353 N.E.2d 793, 794 (N.Y. 1976) (forbidding award of punitive damages in arbitration), superseded by statute, Federal Arbitration Act, 9 U.S.C. §§ 3, 4 (2006).

298. 514 U.S. 938, 944-47 (1995).

299. See supra notes $142-47$ and accompanying text.

300. See Prima Paint Corp. v. Flood \& Conklin Mfg. Co., 388 U.S. 395, $403-07$ (1967); see also First Options, 514 U.S. at 945-46.

301. First Options, 514 U.S. at 947.

302. Id. at $947-48$. 
In addition to being a middle-of-the-road, uneventful decision, First Options tends to avoid the excesses of arbitral infatuation in its rhetoric, approach, and decision, and it stands as a moment of relative lack of passion by the Court regarding arbitration. But in another decision from that year, Vimar Seguros y Reaseguros, S.A. v. M/V Sky Reefer, the Court reverted to its pro-arbitration amore in refusing to apply the Carriage of Goods by Sea Act (COGSA) to prevent arbitration of a dispute in Japan pursuant to a clause in a bill of lading for a shipment of oranges from Morocco to Boston, which also included a Japanese choice-of-law provision. ${ }^{303}$ COGSA provides that:

[a]ny clause, covenant, or agreement in a contract of carriage relieving the carrier or the ship from liability for loss or damage to or in connection with the goods, arising from negligence, fault, or failure in the duties and obligations provided in this section, or lessening such liability otherwise than as provided in this chapter, shall be null and void and of no effect. ${ }^{304}$

Given a plain reading, COGSA would appear to foreclose imposition of an arbitration agreement if arbitration resulted in any shrinkage of claimant remedies. But the Court majority avoided this seeming command by holding that the arbitration and choice-of-law clauses were not provisions "lessening . . liability."305 Justice Stevens explained in dissent:

The foreign-arbitration clause imposes potentially prohibitive costs on the shipper, who must travel—and bring his lawyers, witnesses, and exhibits - to a distant country in order to seek redress. ... .

$\cdots$

The Court assumes that the words "lessening such liability" must be narrowly construed to refer only to the substantive rules that define the carrier's legal obligations. Under this view, contractual provisions that lessen the amount of the consignee's net recovery, or that lessen the likelihood that it will make any recovery at all, are [erroneously placed] beyond the scope of the statute.

In my opinion, this view is flatly inconsistent with the purpose of

303. 515 U.S. 528, 530 (1995).

304. 46 U.S.C. App. § 1303(8) (2002) (current version recodified in notes for section of 46 U.S.C. 30701 (2006)).

305. Vimar Seguros, 515 U.S. at 536-37. 
COGSA $\S 3(8) .{ }^{306}$

306. Id. at 549-50 (Stevens, J., dissenting) (citations omitted). 
In effect, the majority, through its minimization of the practical impact of the arbitration clause's dictating a distant and inconvenient forum and distant applicable law, held that COGSA, enacted in 1936-a decade after the Act-was trumped by the Act, notwithstanding that COGSA is as much substantive law as the Act. Further, the case presented a rather sympathetic shipper forced to adhere to a one-sided contract that might well fail unconscionability analysis under state law. As Justice Stevens' dissent noted, COGSA was enacted to correct such problems. $^{307}$

Once again reviewing section 2 of the Federal Arbitration Act, which makes arbitration clauses specifically enforceable "save upon such grounds as exist at law or in equity for the revocation of any contract,",308 Justice Stevens observed that:

[t]his language plainly intends to place arbitration clauses upon the same footing as all other contractual clauses. Thus, like any clause, an arbitration clause is enforceable, "save upon such grounds" as would suffice to invalidate any other, nonarbitration clause. The FAA thereby fulfills its policy of jettisoning the prior regime of hostility to arbitration. Like any other contractual clause, then, an arbitration clause may be invalid without violating the FAA if, for example, it is procured through fraud or forgery; there is mutual mistake or impossibility; the provision is unconscionable; or, as in this case, the terms of the clause are illegal under a separate federal statute which does not evidence a hostility to arbitration. Neither the terms nor the policies of the FAA would be thwarted if the Court were to hold today that a foreign arbitration clause in a bill of lading "lessens liability" under COGSA. COGSA does not single out arbitration clauses for disfavored treatment; it invalidates any clause that lessens the carrier's liability. Illegality under COGSA is therefore an independent ground "for the revocation of any contract," under FAA $\S 2$. There is no conflict between the two federal statutes. ${ }^{309}$

Justice Stevens attributed the majority's error to "overzealous formalism, ${ }^{\text {„10 }}$ but the decision appears just as much to be a preference for arbitration regardless of the text, intent, or purpose of the Act-a preference embraced by the Court in spite of the Act's direction that arbitration agreements be subject to the same contract-based defenses to

307. Id. at 550; see also id. at 545-46 (noting academic support for enforcing COGSA and similar precedent authored by respected Second Circuit Judge Henry Friendly).

308. 9 U.S.C. $\S 2$ (2006).

309. Vimar Seguros, 515 U.S. at 555-56 (Stevens, J., dissenting).

310. Id. at 556 . 
enforcement listed by Justice Stevens. Just as disturbingly, Justice Stevens dissented alone. A supermajority of the Court was sufficiently infatuated by arbitration that it pursued it even in the face of contrary substantive law.

Similar substantive preferences for arbitration over states' rights, federalism, and the right to regulate were reflected a year later in Doctor's Associates, Inc. v. Casarotto. ${ }^{311}$ A Subway sandwich shop franchisee sought to avoid arbitration of his dispute with the franchisor based on the failure of the arbitration clause in the agreement to comply with the requirements of a Montana statute, which provided that "[n]otice that a contract is subject to arbitration... shall be typed in underlined capital letters on the first page of the contract; and unless such notice is displayed thereon, the contract may not be subject to arbitration.” 312

Reversing the Montana Supreme Court, the U.S. Supreme Court held the provision was in violation of the Arbitration Act because the state law did not apply to the revocation of "any" contract but only to arbitration agreements. ${ }^{313}$ Justice Ginsburg's majority opinion enjoyed a supermajority, with only Justice Thomas in dissent, reiterating his view that Southland was wrongly decided. ${ }^{314}$

Notwithstanding the strength of the Court's vote and its consistency with federal appeals court decisions taking a similarly dim view of analogous state laws, Casarotto reads like an opinion written by a court in the sway of arbitration and wishing to promote it in spite of legitimate countervailing state goals. The Montana statute is not a ban on specific enforcement of arbitration clauses but simply a means of forcing disclosure to attempt to ensure that arbitration agreements are consensual.

The Montana law was vulnerable to preemption by the Act because it singled out arbitration. But this presumably reflected state concern that arbitration agreements presented particularly pressing problems of disclosure, consent, and fairness. A Court less infatuated with arbitration could have respected the traditional state domain of contract law and been consistent with the Act. Although the state statute placed an additional burden on the drafters of arbitration agreements, the burden is

311. 517 U.S. 681 (1996).

312. Id. at 684 (quoting MoNT. CODE ANN. § 27-5-114(4) (1995) (amended 1997)).

313. Id. at 688 .

314. Id. at 689 (Thomas, J., dissenting). 
light, merely requiring a disclosure provision rather than imposing a substantive bar to arbitration. Further, a Court less driven to require arbitration could have considered other contract-based defenses to arbitrability and whether Montana's information-forcing statute was simply a form of similar state-centered policing of contracts. ${ }^{315}$

After a four-year break from arbitration cases, the new century saw the Court return to the topic and largely continue its pro-arbitration approach. ${ }^{316}$ In Green Tree Financial Corp.-Alabama v. Randolph, the Court ruled that an arbitration agreement that does not specifically set forth information about the costs and fees of arbitration is nonetheless enforceable. ${ }^{317}$ The Court in effect rejected the view that such silence was per se unconscionable as a matter of federal common law. ${ }^{318}$ Justice Ginsburg, joined by Justices Stevens, Souter, and Breyer, concurred in part and dissented in part, arguing that instead of making a definitive pronouncement on the issue, the Court should have remanded the case for "closer consideration of the arbitral forum's accessibility" and potential unconscionability in light of the lack of disclosure about costs and fees. ${ }^{319}$ This decision continued the Court's affection for arbitration and reflected some division within the Court as well as the Court's overall resistance to unconscionability analysis.

Then came Circuit City Stores, Inc. v. Adams, in which the Court expressly addressed the issue it had dodged in Gilmer $v$. Interstate/Johnson Lane Corp., albeit hinting at a bad result for workers whenever forced to face the issues squarely. The Circuit City Court ruled that section 1 of the Act, which prohibits enforcement of arbitration clauses in employment contracts, did not apply to all workers engaged in activity affecting commerce but only applied to those directly involved in the interstate movement of goods. ${ }^{320}$ In reaching this result, the Court

315. See Stephen Ware, Arbitration and Unconscionability After Doctor's Associates, Inc. v. Casarotto, 31WAKE FOREST L. REV. 1001, 1002 (1996) (advocating a contractual approach to issues of unconscionability in arbitration).

316. In Cortez Byrd Chips, Inc. v. Bill Harbert Construction Co., a unanimous and uncontroversial decision, the Court held that the venue provisions of the Arbitration Act are permissive and allow a motion for confirming, vacating, or modifying an arbitration award to be filed either in the federal district court where the award was made or in any other federal district court where venue is proper under the general venue statute. 529 U.S. 193, 195 (2000)

317. 531 U.S. 79, 82 (2000).

318. Id. at 89-92.

319. See id. at 93-96 (Ginsburg, J., dissenting) (arguing that the Court should have considered Green Tree's practice under the form contract and the financial inaccessibility of the arbitral forum to Randolph).

320. See 532 U.S. 105, 112, 119 (2001) (stating that most courts of appeal limit the exclusion 
took a narrow construction of section 1 and limited its protections to transportation workers. ${ }^{321}$

As he had in Gilmer, Justice Stevens dissented, this time enjoying support from Justices Ginsburg, Breyer, and Souter. ${ }^{322}$ As in Gilmer, Justice Stevens reviewed the legislative history of the Act and convincingly showed a congressional desire to protect workers subject to contracts of adhesion that contain arbitration clauses. ${ }^{323}$ Although the language of section 1 could have been broader, it not only singles out seamen and railroad workers, but it includes the catchall of "any other class of workers engaged in foreign or interstate commerce" ${ }^{\text {"324 }}$ language broad enough to encompass workers involved in nontransportation activities implicating interstate commerce. Early cases construing section 1 took this view, and it was not until Tenney Engineering, Inc. v. United Electrical \& Machine Workers of America, Local 437 that a contrary view arose in the circuits, ${ }^{325}$ creating a split at the time of the Circuit City decision.

In addition to criticizing the majority's pre-arbitration reading of section 1, Justice Stevens made a persuasive case that the majority ignored both the congressional intent and legislative purpose underlying the statute:

It is not necessarily wrong for the Court to put its own imprint on a statute. But when its refusal to look beyond the raw statutory text enables it to disregard countervailing considerations that were expressed by Members of the enacting Congress and that remain valid today, the Court misuses its authority. As the history of the legislation indicates, the potential disparity in bargaining power between individual employees and large employers was the source of organized labor's opposition to the Act, which it feared would require courts to enforce unfair employment contracts.... When the Court simply ignores the interest of the unrepresented employee, it skews its interpretation with its own policy preferences.

... A method of statutory interpretation that is deliberately uninformed, and hence unconstrained, may produce a result that is consistent with a

\footnotetext{
provision to employees actually moving goods in interstate commerce and adopting this as the appropriate interpretation); see supra text accompanying notes 270-84 (discussing Gilmer).

321. See Circuit City, 532 U.S. at 119.

322. Id. at 124 (Stevens, J., dissenting).

323. See id. at 125-29 (reviewing legislative history of section 1 of the Act).

324. 9 U.S.C. $\S 1$ (2006).

325. 207 F.2d 450 (3d Cir. 1954); see Stempel, supra note 282 (providing a detailed description of the case law of section 1 prior to Gilmer and Circuit City).
} 
court's own views of how things should be, but it may also defeat the very purpose for which a provision was enacted. That is the sad result in this case. ${ }^{326}$

Justice Souter's dissent, also joined by the other three dissenters, noted the difficult-to-defend inconsistency between the Court's broad construction of section 2, which makes arbitration agreements specifically enforceable save for contract-based revocation defenses, and the Court's narrow construction of section 1 so as to limit employee protection to only transportation workers. ${ }^{327}$

The dissenting opinions by Justices Stevens and Souter persuasively argue that the Circuit City majority largely turned its back on legislative history considerations in favor of reading statutory text in an unnatural manner designed to implement the majority's policy preference for arbitration of employment disputes. ${ }^{328}$ In effect, the four dissenters accuse the five Justices in the majority of spurning traditional statutory interpretation jurisprudence that all of the majority judges-Justices Rehnquist, Kennedy, O'Connor, Scalia, and Thomas-profess to embrace, instead favoring imposition of the majority's personal preferences for private ordering and reduced litigation.

After a period of relative quiet on the arbitration front, ${ }^{329}$ the Court returned to the issue in substantial, but confusing, fashion in 2003 with the decision in Green Tree Financial Corp. v. Bazzle. ${ }^{330}$ Reviewing state

\footnotetext{
326. Circuit City, 532 U.S. at 132-33 (Stevens, J., dissenting).

327. Id. at 133-35.

328. Id. at 131; id. at 136 (Souter, J., dissenting).
}

329. The 2002-2003 time period broke the mold slightly with one decision favorable to workers suffering discrimination. In EEOC v. Waffle House, Inc., the Court, in an opinion by Justice Stevens, held that an arbitration agreement between an employee and his restaurant employer did not bind the Equal Employment Opportunity Commission (EEOC) from seeking relief in court for the employee because the EEOC was not a party to the arbitration clause or its container contract. 534 U.S. 279, 297-98 (2002). Justice Thomas, joined by Justices Rehnquist and Scalia, objected, arguing that the Act required enforceability and that the EEOC was bound by the agreements made by the plaintiffs whose causes it may take up in litigation. See id. at 298 (Thomas, J., dissenting).

Two other decisions, however, continued to be highly supportive of arbitrability. In Howsam v. Dean Witter Reynolds, Inc., the Court held that the meaning of a limitation provision in the National Association of Securities Dealers (NASD) Code of Arbitration Procedure was a matter to be determined by the arbitrator rather than the court. 537 U.S. 79, 84-85 (2002). In Citizens Bank v. Alafarbco, Inc., the Court's per curiam opinion followed Allied-Bruce Terminex Cos. v. Dobson, holding that debt restructuring agreements made in Alabama between Alabama residents nonetheless had a sufficient connection to interstate commerce to fall within the Act. Alafarbco, 539 U.S. 52, 55-56 (2003); Dobson, 513 U.S. 265 (1995). The Court found agreements were contracts evidencing a transaction involving commerce within the meaning of the Act. Id. at 56.

330. 539 U.S. 444 (2003). 
court decisions permitting an arbitrator to accord class action treatment to homeowners contending that their commercial lender had violated the South Carolina Consumer Protection Code, the Court vacated the South Carolina high court's ruling, holding that although the Federal Arbitration Act did not clearly preclude class arbitration, the matter required more scrutiny according to state contract law. ${ }^{331}$ The decision is odd and seems not to accomplish much other than falling short of finding a wholesale prohibition on class arbitration in the Act. To that extent, it is not particularly indicative of either affection for or opposition to arbitration. Surprisingly, the decision engendered dissents by Justice Rehnquist, joined by Justices O'Connor and Kennedy, ${ }^{332}$ and Justice Thomas, ${ }^{333}$ as well as a concurrence and dissent by Justice Stevens. ${ }^{334}$

Justice Stevens would have simply affirmed, in part because the petitioner did not appear to preserve a challenge to this issue of whether the state courts improperly decided a question of class arbitration that should have been for the arbitrator in the first instance. ${ }^{335}$ Justice Thomas again reiterated his view that Southland was wrongly decided. ${ }^{336}$ Justices Rehnquist, O'Connor, and Kennedy thought reversal was the apt remedy because the matter was one for the courts rather than the arbitrator, and in their view, the contract in question did not permit class arbitration, making the state court decision a violation of the federal Act. $^{337}$

\section{The Roberts Court: A More Tainted Kind of Love}

From the uncertainty of Bazzle, the Court returned to more obvious policy preference for arbitration in Buckeye Check Cashing, Inc. v. Cardegna. $^{338}$ In Buckeye, the Court addressed a variant of the Prima Paint issue of allocation of initial interpretative authority between the courts and arbitrators. ${ }^{339}$ The Court held that the issue of whether an allegedly usurious contract containing an arbitration clause was illegal

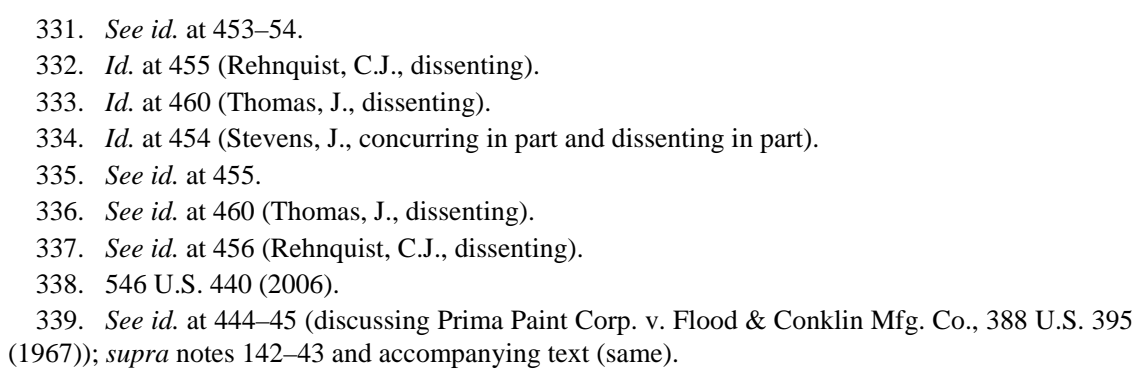


and thus void and unenforceable was for the arbitrator to decide, ${ }^{340}$ a result that can be justified under Prima Paint even if incorrect or unwise. Buckeye is thus an example of continued affection for arbitration and a desire to keep more dispute resolution activity before the arbitrator rather than the courts. But it is not an outrageous example of the Court swooning over arbitration. Justice Thomas was again a voice in the wilderness, contending that the Act, if properly interpreted, applies only in federal courts. ${ }^{341}$ Justice Alito did not participate. ${ }^{342}$

More obvious substantive favoritism of arbitration was reflected in Preston v. Ferrer, in which the Court, with Justice Thomas in lone dissent, ${ }^{343}$ held that the Federal Arbitration Act supersedes state law that would in the absence of arbitration rest primary jurisdiction over a dispute in an administrative forum. ${ }^{344}$ The Court viewed the state law requiring exhaustion of administrative remedies as a prerequisite to arbitration as an obstacle to arbitration in conflict with the federal Act. ${ }^{345}$

Ironically, the case involved a dispute between a television "judge" and his attorney/agent. ${ }^{346}$ The judge sought to have the matter determined by the California Labor Commissioner rather than an arbitrator. $^{347}$ The California appellate court supported this request, finding Buckeye Check Cashing inapposite because there had been no question of primary administrative agency jurisdiction in Buckeye. ${ }^{348}$ The Court rejected the distinction in an opinion that continued the Court's infatuation with arbitration but that was no more pro-arbitration than the existing Prima Paint and Buckeye precedents.

Hall Street Associates, LLC v. Mattel, Inc., arguably takes the proarbitration sentiment of the Court further by preventing parties to an arbitration agreement from consensually expanding judicial review of arbitration. ${ }^{349}$ Hall Street held that parties to an arbitration agreement could not stipulate to more searching judicial review of any resulting

\footnotetext{
340. See Buckeye, 546 U.S. at 445-47.

341. See id. at 449 (Thomas, J., dissenting).

342. Id. at 441 (majority opinion).

343. 552 U.S. 346, 363 (2008) (Thomas, J., dissenting) (restating the argument that the Act did not apply in state court proceedings).

344. Id. at 349-51 (majority opinion).

345. See id. at 360-63.

346. Id. at 350 .

347. Id. at 350-51.

348. See Ferrer v. Preston, 51 Cal. Rptr. 3d 628, 634 (Ct. App. 2006), rev'd, 552 U.S. 346, 346 (2008).

349. Hall Street, 552 U.S. at 578.
} 
award, in particular de novo review of the arbitrator's legal determinations rather than the more limited menu of grounds for vacating an award set forth in section 10 of the Act. ${ }^{350}$ The Court viewed this as improper attempts by disputants to change the applicable law or to attempt to control the courts. ${ }^{351}$

Justices Stevens, Kennedy, and Breyer dissented. ${ }^{352}$ All essentially argued that the Arbitration Act did not preclude agreements to enlarge the scope of review. Justice Stevens noted that there was precedent permitting such agreements prior to the Act and that neither the text nor the legislative history of the Act suggested that Congress intended to overturn these precedents. ${ }^{353}$ Hall Street, however interesting, does not give a clear signal regarding the Court's preferences for arbitration over litigation. But the decision appears to strengthen the power of arbitration by preventing judicial review in excess of that provided by section 10 of the Act rather than protect the courts from litigants' efforts to control the courts' discharge of statutory duty.

After two relatively minor decisions in $2009,{ }^{354}$ the Court's arbitration jurisprudence took increasingly wrong turns in 2010 and 2011. With Stolt-Nielsen S.A. v. AnimalFeeds International Corp., the Court's recent arbitration jurisprudence became particularly problematic and unsatisfying, in part because its romance with arbitration began to appear fickle, or at least compromised of favoritism depending on who was pursuing arbitration combined with a significant but unfounded aversion to class action treatment of cases. ${ }^{355}$

In Stolt-Nielsen, a customer sought class action proceedings in its arbitration with the shipper when accusing the shipper of illegal price

\footnotetext{
350. Id. at 586.

351. See id. at 590-92.

352. See id. at 592 (Stevens, J. and Kennedy, J., dissenting); id. at 596 (Breyer, J. dissenting).

353. See id. at 595 n.3 (Stevens, J., dissenting).

354. In Vaden v. Discover Bank, the Court held that judges may look through a petition to compel arbitration to determine whether the court has jurisdiction over the matter rather than relying solely on the averments of the petition. 556 U.S. 49, 53-54 (2009). Vaden is thus probably more of a vindication of judicial authority than a reflection of arbitral infatuation. In Arthur Andersen LLP $v$. Carlisle, the Court held that an entity or person not party to the underlying agreement containing an arbitration clause nonetheless had standing to request a stay of court action on a matter pending in arbitration. 129 S. Ct. 1896, 1903 (2009). By expanding standing to seek judicial relief in support of arbitration, the decision continued the Court's tendency to embrace arbitration. Justice Souter, as joined by Chief Justice Rehnquist and Justice Stevens, dissented on grounds that the matter was not ripe for appeal but appeared not to disagree with the majority's substantive decision regarding the Federal Arbitration Act. See id. at 1903-04 (Souter, J., dissenting).
}

355. 130 S. Ct. 1758 (2010). 
fixing. ${ }^{356}$ The arbitration clause of the shipping contract used broad language, and no one contested that the matter was subject to arbitration. ${ }^{357}$ But the shipper opposed class action treatment of the claim. $^{358}$ The appointed arbitrators considered the issue and, after a hearing, determined the parties should proceed with class treatment of the case, though they stayed the proceedings pending judicial review. ${ }^{359}$

The federal district court vacated this "award" on the ground that the arbitrators had shown "manifest disregard" of the law because they had failed to conduct a choice-of-law analysis. ${ }^{360}$ The Second Circuit reversed and reinstated the arbitration panel decision. ${ }^{361}$ The Supreme Court vacated the decision to proceed on a class basis, holding that class treatment was improper absent sufficient proof that the shipper had affirmatively consented to class action arbitration. ${ }^{362}$

Stolt-Nielsen, a relatively close 6-3 decision, could be viewed as curtailing the Court's general affinity for arbitration. The decision has the immediate practical effect of limiting an arbitration panel's power over a dispute. But Stolt-Nielsen reflects not so much a cooling of arbitral ardor as a revelation that the Court's love of arbitration is a reckless and irresponsible affair. In most of the post-Southland cases, the Court has given no serious consideration to issues of consent in the formation of an arbitration agreement. But in Stolt-Nielsen, where the party resisting broader arbitration held greater commercial power and the relief requested would empower claimants, the Court was suddenly gripped with concern over whether sufficient consent to arbitrate existed. $^{363}$

Perhaps the Court hates antitrust claimants or class action treatment of disputes even more than it loves arbitration. But this hardly makes for sound adjudication. Rather, it exposes the Court's own inconsistency and favoritism. More sound and persuasive is Justice Ginsburg's dissent, which Justices Stevens and Breyer joined. ${ }^{364}$ In addition to making the

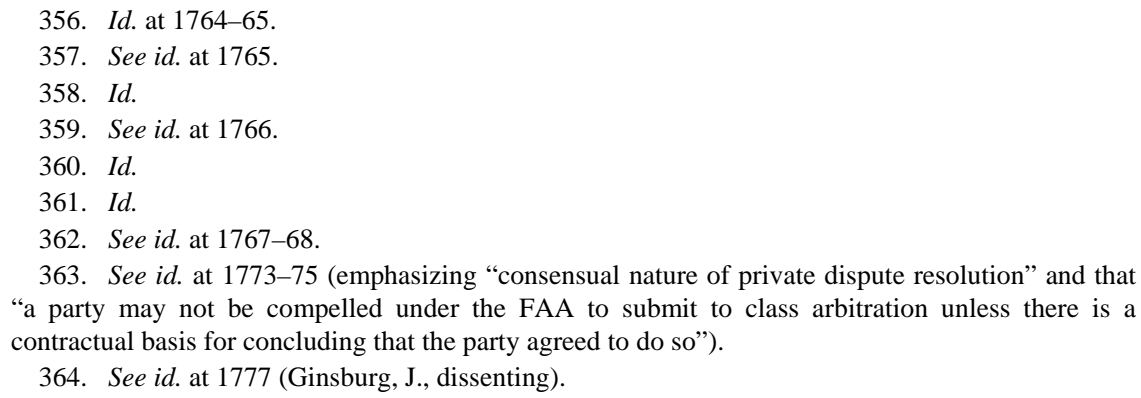


argument that the matter was not a final award subject to review under section $10,{ }^{365}$ the dissent took the sensible view that an arbitration agreement ordinarily carries with it an agreement to arbitrate according to whatever rules govern the proceeding as applied by the arbitrators:

Even if [the shipper] had a plea ripe for judicial review, the Court should reject it on the merits. Recall that the parties jointly asked the arbitrator to decide, initially, whether the arbitration clause in their shipping contracts permitted class proceedings. The panel did just what it was commissioned to do. It construed the broad arbitration clause (covering "[a]ny dispute arising from the making, performance or termination of this Charter Party,” and ruled, expressly and only, that the clause permitted class arbitration. The Court acts without warrant in allowing Stolt-Nielsen essentially to repudiate its submission of the contract-construction issue to the arbitration panel, and to gain, in place of the arbitrators' judgment, this Court's de novo determination.

The controlling FAA prescription, § 10(a), authorizes a court to vacate an arbitration panel's decision “only in very unusual circumstances.

As the dissent also accurately noted, the majority unfairly and inaccurately characterized the arbitration panel decision as being one of policy preference for class action treatment despite that the words "policy" or "public policy" were "not so much as mentioned" by the panel, which instead "tied its conclusion that the arbitration clause permitted class arbitration" on contract language, historical practices, applicable rules, and the record as informed by expert testimony. ${ }^{367}$

"The question properly before the Court is not whether the arbitrators' ruling was erroneous but whether the arbitrators 'exceeded their powers' [under section 10(a)(4)]. The arbitrators decided a threshold issue, explicitly committed to them, about the procedural mode

\footnotetext{
365. See id. at 1778 . The majority emphasized consent and noted that "a party may not be compelled under the FAA to submit to class arbitration unless there is a contractual basis for concluding that the party agreed to do so.” Id. at 1774-75 (majority opinion). The dissent responded by arguing that "[t]he Court ... does not persuasively justify judicial intervention so early in the game, or convincingly reconcile its adjudication with the firm final-judgment rule prevailing in the federal court system.” Id. at 1778 (Ginsburg, J., dissenting). Justice Ginsburg additionally noted that "[n]o decision of this Court, until today, has ever approved immediate judicial review of an arbitrator's decision, as preliminary as the 'partial award' made in this case." Id. at 1779 (footnote omitted).

366. Id. at 1779-80 (Ginsburg, J., dissenting) (citations omitted).

367. See id. at $1780-81$.
} 
available for presentation of AnimalFeeds' antitrust claims.”368 Making good use of the Court's then-recent opinion in Shady Grove Orthopedic Associates, P.A. v. Allstate Insurance Co. that had permitted class action litigation against an Erie challenge, ${ }^{369}$ the dissent, quoting Shady Grove, noted that "'rules allowing multiple claims (and claims by or against multiple parties) to be litigated together ... neither change plaintiffs' separate entitlements to relief nor abridge defendants' rights; they alter only how the claims are processed.",370 The author of Shady Grove was Justice Scalia, a member of the Stolt-Nielsen majority. ${ }^{371}$

Succinctly noting the logical flaw in the reasoning of the StoltNielsen majority, the dissent observed that "[f]or arbitrators to consider whether a claim should proceed on a class basis, the Court apparently demands contractual language one can read as affirmatively authorizing class arbitration. The breadth of the arbitration clause, and the absence of any provision waiving or banning class proceedings, will not do.”372 But the law of arbitrability as set forth in the Court's pre-Stolt-Nielsen cases of the modern era has been broad construction of broadly worded arbitration agreements and the presumption that, unless stated to the contrary, arbitration generally should be able to accord the same remedies that are available in litigation.

As the dissent also noted, the right question in cases like StoltNielsen seeks "the proper default rule when there is no stipulation."373 Where industry-wide arbitration is the norm, one would logically expect the dispute resolution norm to be one of according full remedies commensurate with the dispute. And, as the dissent also noted "[w]hen adjudication is costly and individual claims are no more than modest in size, class proceedings may be 'the thin,' i.e., without them, potential claimants will have little, if any, incentive to seek vindication of their rights." ${ }^{374}$

In Rent-A-Center, West, Inc. v. Jackson, the Court was back in unbridled pro-arbitration mode, holding that an arbitration clause challenged as unconscionable by a former employee bringing a 42 U.S.C. $§ 1981$ discrimination suit must first be assessed by the arbitrator

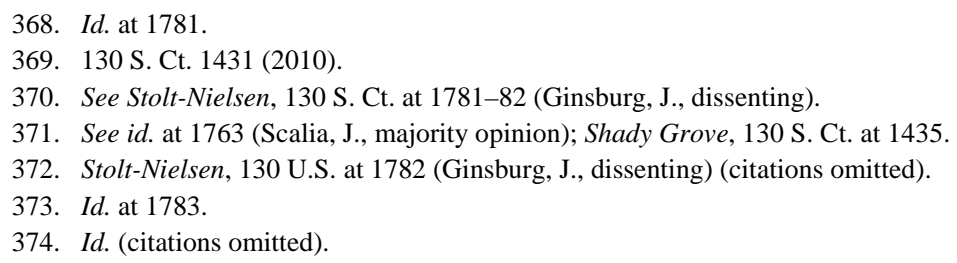


rather than the court. ${ }^{375}$ The clause was broadly drafted, stating that the arbitrator, "and not any federal, state, or local court or agency, shall have exclusive authority to resolve any dispute relating to the interpretation, applicability, enforceability or formation" of the agreement and was "not limited to any claim that all or any part of [the agreement was] void or voidable." ${ }^{376}$ But by reading the clause broadly and literally to preclude judicial assessment of the fairness of the provision, the Court ignored the very language of section 2 of the Act, which permits contract-based claims for revocation of an arbitration agreement. ${ }^{377}$

Coming less than two months after the Court's concern in StoltNielsen over whether a large shipping company had adequately consented to class treatment of allegations that it had engaged in price fixing, it is jarring to see little or no concern over the employee's consent to a clause that sought to oust courts from even the jurisdiction left to them by the drafters of the Act. Similarly odd is the Rent-A-Center Court's willingness to permit this when only two years earlier it was unwilling to permit the expanded judicial review of arbitration awards sought by the contracting parties in Hall Street. ${ }^{378}$ The decisions seem irreconcilable except by reference to a raw preference for arbitration with limited judicial involvement-but, under Stolt-Nielsen, for piecemeal arbitration of claims rather than class treatment.

The majority's reasoning is circular in that it prevents-until after an award and a section 10 challenge to the award-judicial scrutiny of the arbitration clause even though the worker's very argument is that the clause suffers from procedural or substantive unconscionability. ${ }^{379}$ In particular, the arbitration clause contained a fee-sharing provision that the trial court determined was not substantively unconscionable and that had been affirmed by the Ninth Circuit, with other unconscionability arguments pending review when the Supreme Court intervened. ${ }^{380}$

\footnotetext{
375. 130 S. Ct. 2772, 2772-73 (2010).

376. Id. at 2775.

377. See 9 U.S.C. § 2 (2006).

378. Hall Street, 552 U.S. 576, 583 (2008). Three days after issuing Rent-A-Center, the Court in Granite Rock Co. v. International Brotherhood of Teamsters, held that a dispute over the ratification date of the collective bargaining agreement at issue was a matter for the court rather than an arbitrator, that the employer did not implicitly consent to arbitration, and that a claim of tortious interference fell outside the scope of the Labor Management Relations Act. 130 S. Ct. 2847, 2853, 2863-66 (2010). In dissent, Justices Sotomayor and Stevens argued that the CBA clearly directs such issues to the arbitrator. See id. at 2866 (Sotomayor, J., dissenting).

379. Rent-A-Ctr., 130 S. Ct. at 2774.

380. The trial court had found no substantive unconscionability as an alternative holding should
} 
its determination that the issue was for the arbitrator be disturbed on review. Id. at 2776 . 
The Rent-A-Center majority justified its holding as a natural extension of Prima Paint and Buckeye, which both held that attacks on contracts containing arbitration clauses are for the arbitrator because such attacks do not question the validity of the arbitration clause. ${ }^{381}$ But allowing arbitrators to assess contract revocation defenses that do not focus on arbitration is one thing. Allowing boilerplate arbitration agreements imposed on employees, who would be free of such clauses had the Court decided Gilmer or Circuit City correctly, is quite another.

With Rent-A-Center, the Court made a big move toward further embracing arbitration. Under Rent-A-Center, it is not enough to require judicial enforcement of arbitration clauses after judicial investigation determines that they apply to the dispute and are not subject to a revocation defense under section $2 .^{382}$ Now, parties favoring arbitration, even the highly problematic mass arbitration that was foreign to the drafters of the Act, can remove courts from the inquiry altogether, restricting the judicial role to its limited authority of policing arbitration awards after the fact pursuant to the limited scope of section 10 of the Act. That is, unless the Court takes an unjustifiably expansive view of section 10, as it did in Stolt-Nielsen.

The pro-arbitration aggressiveness of Rent-A-Center engendered a 54 split in the Court. ${ }^{383}$ As in so many of the Court's arbitration decisions of the past twenty years, the dissenting arguments appear more consistent with statutory text, legislative intent and purpose, and deference to state contract law. ${ }^{384}$ In addition, the dissent holds truer to judicial precedent:

The Court's decision today goes beyond Prima Paint. Its breezy assertion that the subject matter of the contract at issue-in this case, an arbitration agreement and nothing more-"makes no difference" is simply wrong. This written arbitration agreement is but one part of a broader employment agreement between the parties, just as the arbitration clause in Prima Paint was but one part of a broader contract for services between those parties. Thus, that the subject matter of the

\footnotetext{
381. Id. at 2778-80; see Buckeye Check Cashing, Inc. v. Cardegna, 546 U.S. 440, 442 (2006); Prima Paint Corp. v. Flood \& Conklin Mfg. Co. 388 U.S. 395, 403-04 (1967); see also supra notes 142-43 and accompanying text (discussing Prima Paint); supra notes 338-42 and accompanying text (discussing Buckeye).

382. Rent-A-Ctr., 130 S. Ct. at 2774.

383. Id.

384. See id. at 2781-88 (Stevens, J., Ginsburg, J., Breyer, J., and Sotomayor, J., dissenting).
} 
agreement is exclusively arbitration makes all the difference in the Prima Paint analysis. ${ }^{385}$

At least for the moment, the Court may have saved its worst for last. Of the many problematic arbitration decisions that seem to run roughshod over settled legal principles, AT\&T Mobility LLC $v$. Concepcion is by far the worst in its direct opposition to the Act's text, legislative history, and architecture, and its disregard of the rights of the states to regulate contracts. ${ }^{386}$

Vincent and Lisa Concepcion purchased mobile phones subject to an AT\&T Mobility (AT\&T) service contract. ${ }^{387}$ And like most cell phone service contracts, the AT\&T contract provided for arbitration, including the right of AT\&T to "make unilateral amendments, which it did to the arbitration provision on several occasions.”388 The Concepcions brought litigation alleging AT\&T improperly charged \$30.22 in sales tax on the supposedly "free" phones they received as part of the service agreement, a complaint that was consolidated with a putative class action alleging fraud and false advertising because the company had advertised the phones as "free" with a service agreement. ${ }^{389}$

AT\&T in turn moved to compel arbitration of the claim. ${ }^{390}$ The Concepcions resisted, asserting "that the arbitration agreement was unconscionable and unlawfully exculpatory under California law because it disallowed classwide procedures."391 Because the arbitration clause forbade class action treatment of claims, the trial court and the Ninth Circuit found it unconscionable under California law on the strength of Discover Bank v. Superior Court. ${ }^{392}$

Notwithstanding that Discover Bank and earlier class action precedent such as Armendariz v. Foundation Health Psychcare Services, Inc. ${ }^{393}$ can be characterized as unconscionability decisions in which the unreasonably unfair terms simply happened to be contained in an

\footnotetext{
385. Id. at 2781-82 (citations omitted); see also id. at 2782 (the question of arbitrability, including defenses to arbitrability, is "an issue the FAA assigns to the courts").

386. 131 S. Ct. 1740 (2011).

387. Id. at 1744 .

388. Id.

389. Id.

390. Id.

391. Id. at 1745 .

392. Id. (citing Discover Bank v. Superior Court, 113 P.3d 1100, 1110 (Cal. 2005) (holding that limitations on remedies such as a ban on class actions were unconscionable contract provisions)).

393. 6 P.3d 669, 771-72 (Cal. 2000).
} 
arbitration clause, ${ }^{394}$ the Concepcion majority specifically characterized the California law as anti-arbitration law that was precluded by the Act:

The question in this case is whether $\S 2$ preempts California's rule classifying most collective-arbitration waivers in consumer contracts as unconscionable. We refer to this rule as the Discover Bank rule.

$\ldots$

California courts have frequently applied this rule [that class action waivers in consumer contracts that limit consumer remedies are unconscionable] to find arbitration agreements unconscionable. ${ }^{395}$

The Concepcion majority construed Discover Bank to be a restriction on arbitration rather than an unconscionability rule of which the AT\&T arbitration agreement ran afoul. ${ }^{396}$ In doing so, it embraced the view of critics who had opposed this application of California unconscionability law. ${ }^{397}$ The Court observed that:

The overarching purpose of the FAA, evident in the text of $\S \S 2,3$, and 4 , is to ensure the enforcement of arbitration agreements according to their terms so as to facilitate streamlined proceedings. Requiring the availability of classwide arbitration interferes with fundamental

394. Id. Other state supreme court cases are consistent with Armendariz and Discover Bank in finding some arbitration agreements unconscionable, not merely because they are arbitration agreements, but because of some other unfairness in the contracting process or the terms of the clause itself, such as lack of mutuality in the parties' access to remedies. See, e.g., Arnold v. United Cos. Lending Corp., 511 S.E.2d 854, 862 (W. Va. 1998); Iwen v. U.S. W. Direct, 977 P.2d 989, 997 (Mont. 1999).

Some scholars have criticized this approach. See, e.g., Christopher Drahozal, Nonmutual Agreements to Arbitrate, 27 I. J. CoRP. L. 537, 547 (2002); Susan Randall, Judicial Attitudes Toward Arbitration and the Resurgence of Unconscionability, 52 BuFF. L. REV. 185, 186-87 (2004). And it appears that most states do not find unconscionability from nonmutuality alone so long as there was sufficient consideration given to the party that lacks mutuality of remedies or procedural options. See Allyson K. Kennett, Case Notes, Showmethemoney Check Cashers, Inc. v. Williams: Show Me the Mutuality-A New Demand Based on an Old Doctrine Changes the Rules for Enforceability of Arbitration Agreements in Arkansas, 54 ARK. L. REV. 621, 631 (2001). But regardless of which perspective is correct, it is unquestionable that the text of the Federal Arbitration Act itself places authority for making this determination in the hands of the state whose contract law governs the disputed arbitration clause. See 9 U.S.C. $§ 2$ (2006).

395. Concepcion, 131 S. Ct. at 1746.

396. Id. at $1746-47$.

397. See id. (citing Stephen A. Broome, An Unconscionable Application of the Unconscionability Doctrine: How the California Courts Are Circumventing the Federal Arbitration Act, 3 Hastings Bus. L.J. 39, 54, 66 (2006); Randall, supra note 394, at 186-87). 
attributes of arbitration and thus creates a scheme inconsistent with the FAA. $^{398}$

Beyond this formalistic but erroneous analysis-in error because it misread the statutory language and congressional intent and purpose as well as ignoring federalism concerns-the Concepcion majority could not resist displaying its infatuation for arbitration as a mode of dispute resolution differing from litigation. ${ }^{399}$ The opinion reads like an "Ode to Arbitration," $" 00$ at least so long as the arbitration is bilateral, limited in scope, and not vested with too many of the leveling characteristics of litigation such as class treatment, liberal joinder of parties, and broad access to discovery. ${ }^{401}$

In particular, the majority saw the California unconscionability law as a barrier that must be dismantled because arbitration works best when bilateral and "is poorly suited to the higher stakes of class litigation" by "increas[ing] risks to defendants." ${ }^{402}$ Once again, the Court was embracing arbitration when it served the interests of the business establishment while also rebuking it as necessary to achieve the same end. The Court was also embracing a view that class treatment of arbitration is so threatening to defendants as to unfairly coerce

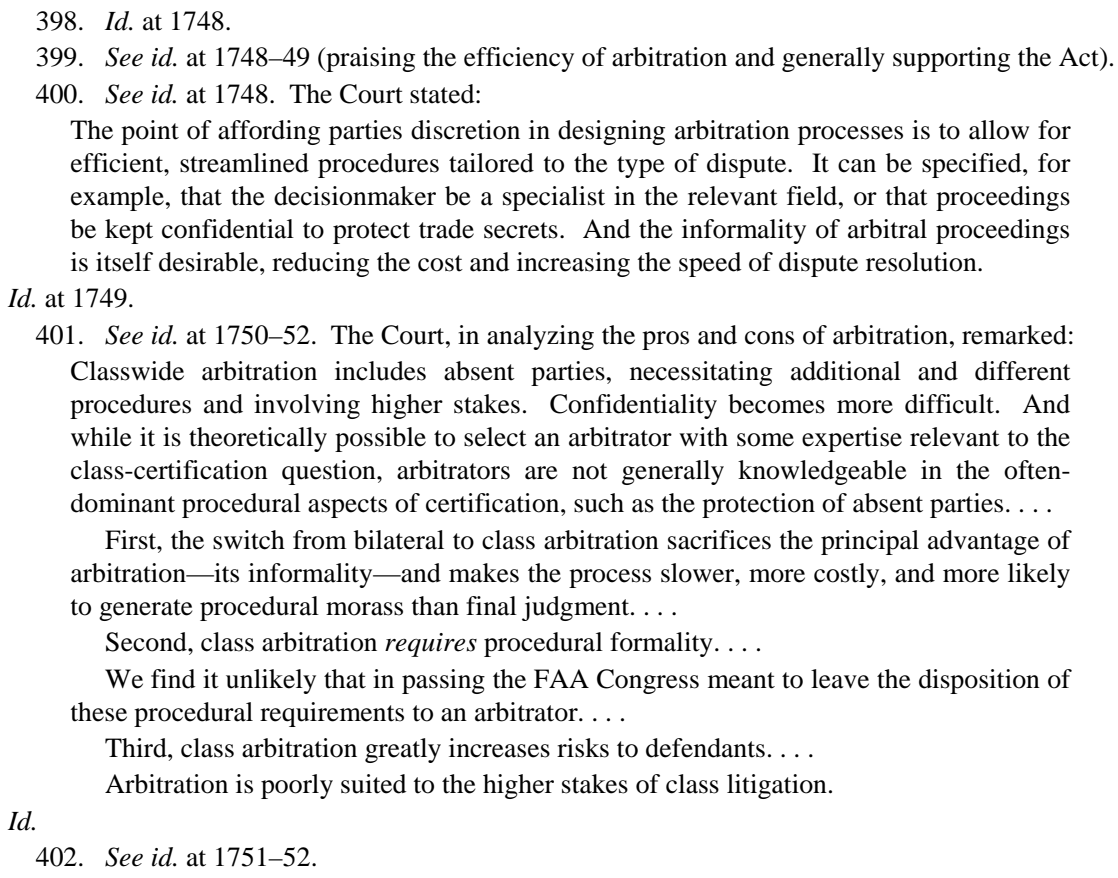

401. See id. at 1750-52. The Court, in analyzing the pros and cons of arbitration, remarked: Classwide arbitration includes absent parties, necessitating additional and different procedures and involving higher stakes. Confidentiality becomes more difficult. And while it is theoretically possible to select an arbitrator with some expertise relevant to the class-certification question, arbitrators are not generally knowledgeable in the oftendominant procedural aspects of certification, such as the protection of absent parties. ...

First, the switch from bilateral to class arbitration sacrifices the principal advantage of arbitration—its informality—and makes the process slower, more costly, and more likely to generate procedural morass than final judgment. ...

Second, class arbitration requires procedural formality. ...

We find it unlikely that in passing the FAA Congress meant to leave the disposition of these procedural requirements to an arbitrator....

Third, class arbitration greatly increases risks to defendants. ...

Arbitration is poorly suited to the higher stakes of class litigation.

402. See id. at 1751-52.

Id. 
settlement. $^{403}$ Although this has long been a rallying cry of forces opposing class actions, the most sophisticated scholarship on the topic has largely debunked this view as a canard. ${ }^{404}$

In Concepcion, the dissenters reflect a stronger commitment to the standard rules of adjudication and a more realistic picture of the practical implications of the decision to which they object. In the main, however, the dissenters are simply truer than the majority to both federalism concerns and legislative intent and purpose:

The Discover Bank rule does not create a "blanket policy in California against class action waivers in the consumer context." Instead, it represents the "application of a more general [unconscionability] principle.” Courts applying California law have enforced class-action waivers where they satisfy general unconscionability standards. And even when they fail, the parties remain free to devise other dispute mechanisms, including informal mechanisms, that, in context, will not prove unconscionable.

The Discover Bank rule is consistent with the federal Act's language....

The Discover Bank rule is also consistent with the basic "purpose behind" the Act. ...

Congress was fully aware that arbitration could provide procedural and cost advantages. ... .

But we have also cautioned against thinking that Congress' primary objective was to guarantee these particular procedural advantages. Rather, that primary objective was to secure the "enforcement" of agreements to arbitrate.

... [C]lass arbitration is consistent with the use of arbitration. It is a form of arbitration that is well known in California and followed elsewhere....

Where does the majority get its contrary idea-that individual, rather than class, arbitration is a "fundamental attribut[e]" of

403. See id. at 1752 ("Faced with even a small chance of a devastating loss, defendants will be pressured into settling questionable claims.”).

404. See, e.g., Charles Silver, "We're Scared to Death": Class Certification and Blackmail, 78 N.Y.U. L. REV. 1357, 1359-60 (2003); Stempel, supra note 24, at 1128-29, 1227-30 (collecting literature debating the degree of coercive force in class actions). 
arbitration? The majority does not explain. And it is unlikely to be able to trace its present view to the history of the arbitration statute itself.

The majority's related claim that the Discover Bank rule will discourage the use of arbitration because "[a]rbitration is poorly suited to ... higher stakes” lacks empirical support. ... .

Further, even though contract defenses, e.g., duress and unconscionability, slow down the dispute resolution process, federal arbitration law normally leaves such matters to the States....

Because California applies the same legal principles to address the unconscionability of class arbitration waivers as it does to address the unconscionability of any other contractual provision, the merits of class proceedings should not factor into our decision. If California had applied its law of duress to void an arbitration agreement, would it matter if the procedures in the coerced agreement were efficient?

Finally, the majority can find no meaningful support for its views in this Court's precedent. The federal Act has been in force for nearly a century. We have decided dozens of cases about its requirements. We have reached results that authorize complex arbitration procedures. We have upheld nondiscriminating state laws that slow down arbitration proceedings. But we have not, to my knowledge, applied the Act to strike down a state statute that treats arbitrations on par with judicial and administrative proceedings.

At the same time, we have repeatedly referred to the Act's basic objective as assuring that courts treat arbitration agreements "like all other contracts." And we have recognized that "[t]o immunize an arbitration agreement from judicial challenge” on grounds applicable to all other contracts "would be to elevate it over other forms of contract." ${ }^{405}$

The dissenters, like the majority, also could not resist a public policy argument. But at least the public policy of the dissenters recognizes the realities of small claims practice and the potential for class treatment to level the playing field upon which larger, wealthier, repeat-player institutional litigants contend with largely unorganized individuals of 
modest means. ${ }^{406}$ More important in terms of the mainstream rules of jurisprudence, the dissent reflects the type of respect for traditional state contract law prerogatives reflected in the text of the Act and its legislative history:

What rational lawyer would have signed on to represent the Concepcions in litigation for the possibility of fees stemming from a \$30.22 claim? In California's perfectly rational view, nonclass arbitration over such sums will also sometimes have the effect of depriving claimants of their claims (say, for example, where claiming the $\$ 30.22$ were to involve filling out many forms that require technical legal knowledge or waiting at great length while a call is placed on hold). Discover Bank sets forth circumstances in which the California courts believe that the terms of consumer contracts can be manipulated to insulate an agreement's author from liability for its own frauds by "deliberately cheat[ing] large numbers of consumers out of individually small sums of money." Why is this kind of decision-weighing the pros and cons of all class proceedings alike-not California's to make? ? $^{407}$

Emphasizing the advantages of their legislative intent and purpose argument, the dissenters noted that Congress was quite clear that in passing the Act: it focused on merchants acting "under the customs of their industries, where the parties possessed roughly equivalent bargaining power." 408

Although the dissent hews considerably closer to mainstream approaches to statutory construction and to the text and legislative intent of the Act than does the majority, the majority was able to put together an argument based on precedent because the Court's arbitration decisions of the prior thirty years had steadily moved away from fidelity to statutory text, legislative intent, the purpose of the Act, and concern for values of consent and fairness in contracting.

While lacking much support in the Act's text or legislative background, ${ }^{409}$ the Concepcion majority was nonetheless able to put

\footnotetext{
406. See id.

407. Id. at 1761 (citations omitted).

408. See id. at 1759 (citing Mitsubishi Motors Corp. v. Soler Chrysler-Plymouth, Inc., 473 U.S. 614, 646 (1985) (Stevens, J., dissenting)); J. Hearings on S. 1005 and H.R. 646 before the Subcomms. of the Comms. on the Judiciary, 67th Cong., 4th Sess., 9-10 (1923); Press Release, Dep't of Commerce, Secretary Hoover Favors Arbitration (Dec. 28, 1925) (on file with the Herbert Hoover Presidential Library); Julius Henry Cohen \& Kenneth Dayton, The New Federal Arbitration Law, 12 VA. L. REV. 265, 281 (1926)).

409. The Concepcion majority's efforts to support its holding based on modern Court precedent is rather well done, presuming one reads the majority's selective summary and quotation of
} 
together a plausible attack on California's approach to unconscionability analysis of arbitration agreements based on decades of case law that had gradually undermined these mainstream bases for construing the Act. ${ }^{410}$ Brick by brick, the Court had erected an edifice of arbitration quite different than Congress intended. Through relatively steady incremental "slouching" away from the core of the original Act and "bootstrapping" upon the rhetorical excesses of each case expanding the Act and diminishing controls on mandated mass arbitration, ${ }^{411}$ the Court by 2011 had effectively judicially rewritten the Act into something fitting the majority's policy preferences.

Incredibly, the Concepcion majority was horrified at the prospect of class-wide administration of arbitration but saw no problems with the world of mass, mandatory arbitration the Court had created over the past

precedent in a vacuum divorced from the actual background history of the Act and the Court's first fifty years of adjudicating disputes under the Federal Arbitration Act. The majority's direct contact with the background of the statute, however, takes on an almost ludicrous tone. For example, the majority criticizes the dissent's assessment of the statute as focused on commercial arbitration among merchants as "[r]elying upon nothing more indicative of congressional understanding than statements of witnesses in committee hearings and a press release of Secretary of Commerce Herbert Hoover.” Id. at 1749 n.5.

This is a little unfair to the dissent, which implicitly considers the entire background of the Act even if it only quotes certain material and grossly mischaracterizes the full genesis of the Act. Scholars investigating the Act have agreed with the dissent's viewpoint that the enacting Congress envisioned an Act specifically enforcing the type of arbitration agreements found in merchants' commercial contracts of the time and not the type of mandated mass consumer arbitration at issue in Concepcion. See HUBER \& WESTON, supra note 104, at 9-11 (providing background on the derivation of the Act); Stempel, supra note 104, at 277-82; see also 1 MACNEIL, SPEIDEL \& STIPANOWICH, supra note $240 \S \S 8: 1-8: 2$ (reviewing the Act's background and legislative history).

410. See Concepcion, 131 S. Ct. at 1746, 1749 (asserting that the Act reflects “'a liberal federal policy favoring arbitration agreements, notwithstanding any state substantive or procedural policies to the contrary"” (quoting Moses H. Cone Mem'l Hosp. v. Mercury Constr. Corp., 460 U.S. 1, 24 (1983))); id. at 1747 (stating that "a court may not 'rely on the uniqueness of an agreement to arbitrate as a basis for a state-law holding that enforcement would be unconscionable"” (quoting Perry v. Thomas, 482 U.S. 483, 493 n.9 (1987))); id. at 1748 (noting that "[t]he 'principal purpose' of the FAA is to 'ensur[e] that private arbitration agreements are enforced according to their terms'” (quoting Volt Info. Scis., Inc. v. Bd. of Trs. of Leland Stanford Junior Univ., 489 U.S. 468, 478 (1989))); id. at 1749 ("Contrary to the dissent's view, our cases place it beyond dispute that the FAA was designed to promote arbitration. They have repeatedly described the Act as 'embod[ying] [a] national policy favoring arbitration' ....” (alterations in original) (quoting Buckeye Check Cashing, Inc. v. Cardegna, 546 U.S. 440, 443 (2006))); id. (stating that requiring the exhaustion of administrative remedies prior to arbitration frustrates the purpose of the Act and "'hinder[s] speedy resolution of the controversy'” (quoting Preston v. Ferrer, 552 U.S. 346, 357-58 (2008))); id. at 1750-51 (criticizing class treatment of disputes as inconsistent with the Act (citing Stolt-Nielsen S.A. v. AnimalFeeds, Int'l Corp., 130 S. Ct. 1758, 1773-76 (2010))); id. at 1753 (stating that the California contract doctrine of unconscionability " "stands as obstacle to the... purposes and objectives of Congress'” expressed in the Act (quoting Hines v. Davidowitz, 312 U.S. 52, 67 (1941))).

411. See Stempel, Bootstrapping and Slouching, supra note 11. 
three decades. ${ }^{412}$ One might ascribe this to jurisprudential myopia, but it seems more likely that the Concepcion majority disliked the former because of its leveling effect between the more and less powerful disputants but embraced the latter because of its inequality-enhancing traits. The arbitration decisions of the Roberts Court line up too neatly in favor of the economically and politically more powerful disputants to be the product of mere inadvertence.

The Concepcion majority was so intent on striking down California's use of the authority provided in section 2 of the Federal Arbitration Act that it exhibited a truly embarrassing moment of judicial amnesia. After criticizing California's Discover Bank doctrine of unconscionability as unduly targeted against arbitration, the Concepcion majority observed that "[o]f course States remain free to take steps addressing the concerns that attend contracts of adhesion-for example, requiring class-actionwaiver provisions in adhesive arbitration agreements to be highlighted." 413 The problem, of course, is that the Court prohibited just this type of state disclosure statute in Doctor's Associates, Inc. v. Casarotto. ${ }^{414}$ The Montana law struck down in Casarotto required that arbitration provisions in franchise contracts be noted in underlined capital letters. $^{415}$ That actual state law pretty closely resembles the hypothetical state disclosure law suggested by the Concepcion Court as an acceptable policing alternative to Discover Bank's unconscionability doctrine. If anything, the Montana statute would seem less of a disclosure burden than highlighting class action waiver provisions as suggested by the Concepcion majority. ${ }^{416}$

412. See Concepcion, 131 S. Ct. at 1746-53 (citing case law from 1983 to 2006 in support of its decision).

413. See id. at 1750 n.6.

414. 517 U.S. 681 (1996)

415. See id. at 683. The Montana law provided that that "[n]otice that [the] contract is subject to arbitration ... [shall be] typed in underlined capital letters on the first page of the contract.” Id. (first alteration in original) (quoting MONT. CODE ANN. § 27-5-114(4) (1995)) (internal quotation marks omitted) An arbitration clause not meeting this provision was rendered unenforceable under Montana law. Id. at 684 .

416. Note 6 of Concepcion is unclear regarding whether a state could make the violation of an apparently permissible state statute requiring the highlighting of a class action waiver grounds for refusing to enforce the arbitration clause or the class action limitations of the clause. See $131 \mathrm{~S}$. Ct. at 1750 n.6. Such was the penalty in Montana for violation of the arbitration disclosure provision at issue in Casarotto. States frequently refuse to enforce contract terms where there have been violations of disclosure requirements. But reading Casarotto as a whole suggests the Court was concerned that not only was the required disclosure singling out and burdening arbitration, but that the statute had an excessively draconian penalty for failing to provide the required disclosure that the contract contained an arbitration clause. See 517 U.S. at 687 ("Courts may not, however, invalidate 
Was the Concepcion majority unaware of Casarotto, a decision only fifteen years old that involved four members of the Concepcion Court, three in the majority ${ }^{417}$ Impossible. The same Concepcion majority suggesting that states respond to its holding with legislation similar to that struck down in Casarotto had just cited Casaratto a mere four pages earlier concerning the types of state contract rules that fell within the purview of section 2 of the Act. ${ }^{418}$

But being aware of a precedent and appreciating its meaning are two different things. A Court with its wits about it would at least have addressed the inconsistency of Concepcion note 6 and Casarotto. But the Concepcion majority failed to do so, and the Concepcion dissent did not address this error by the majority. ${ }^{419}$ One can make attempts to distinguish Casarotto and Concepcion, but any attempted distinction seems doomed to unpersuasiveness. ${ }^{420}$ How can a requirement of minimally adequate disclosure of arbitration in a franchise agreement violate the Act while a requirement of forced disclosure of the limitations on class actions in an arbitration clause complies with the Act? ${ }^{421}$

arbitration agreements under state laws applicable only to arbitration provisions.” (citation omitted)); id. at 687-88 (highlighting the Court's concern over state laws which invalidate arbitration clauses in general); see also supra notes 311-15 and accompanying text.

417. Justices Scalia, Kennedy, Thomas, Ginsburg, and Breyer were all members of both the Casarotto Court and the Concepcion Court. Casarotto, 517 U.S. at 682; Concepcion, 131 S. Ct. at 1743.

418. See Concepcion, 131 S. Ct. at 1746 ("This saving clause [of section 2 of the Act] permits agreements to arbitrate to be invalidated by 'generally applicable contract defenses, such as fraud, duress, or unconscionability,' but not by defenses that apply only to arbitration or that derive their meaning from the fact that an agreement to arbitrate is at issue." (quoting Casarotto, 517 U.S. at $687)$ ).

419. The Concepcion dissent cited Casarotto only in passing in a string citation for the proposition that that Court's precedents "have repeatedly referred to the Act's basic objective as assuring that courts treat arbitration agreements 'like all other contracts.'” Concepcion, $131 \mathrm{~S}$. Ct. at 1761 (Breyer, J., Ginsburg, J., Sotomayor, J., and Kagan, J., dissenting) (gathering cases).

420. See Concepcion, 131 U.S. at 1750 n.6 (majority opinion). One sentence after inviting California to consider legislation similar to the Montana statute struck down in Casarotto, the Court cautioned that "[s]uch steps cannot, however, conflict with the FAA or frustrate its purpose to ensure that private arbitration agreements are enforced according to their terms." Id. Trying to be fair to the majority, one could seize upon this last sentence as a means of distinguishing Casarotto from the type of hypothetical state disclosure legislation that the Concepcion majority appears to be suggesting as a substitute for the Discover Bank approach to unconscionability. But, a reasonably neutral observer could not regard such a proffered distinction as persuasive.

421. If the Concepcion Court meant what it wrote in note 6, then the type of state disclosure regulation seemingly approved therein could significantly mitigate the potential unfairness of mandatory mass arbitration. In light of Concepcion's seeming obliviousness to the conflict between note 6 and Casarotto, however, state legislatures will probably be reluctant to follow the Court's suggestion. 
In a separate concurrence, Justice Thomas stakes out a strained position, one that is particularly surprising coming from the Justice who had until recently continued to argue that Southland was wrongly decided and that the Federal Act did not apply in state court. ${ }^{422}$ According to Justice Thomas, Discover Bank's brand of unconscionability could not thwart the arbitration sought by AT\&T because it "does not relate to defects in the making of the agreement." Surely this view is incorrect, because section 2 of the Act speaks of any contract doctrine that relates to revocation. A contract can be revocable for infirmities other than those going directly to the contracting process.

\section{CONCLUSION: THE CONTINUATION OF THE AFFAIR}

Looking back on nearly thirty years of Supreme Court affection for arbitration, the record is not a particularly attractive one for proponents of the rule of law or fans of constrained judging that does not unduly reflect the personal political, social, economic, and ideological preferences of the bench.

For the most part, the Court has been caught up in the same uncritical support for arbitration that society has shown during the same time period. Business is in vogue while government is out of favor. ${ }^{424}$ Litigation is considered wasteful while private ordering is revered. ${ }^{425}$

422. Concepcion, 131 S. Ct. at 1753 (Thomas, J., concurring); see supra text accompanying note 333 (discussing Justice Thomas's traditional view that the Federal Arbitration Act governed actions in federal court but did not set forth substantive law applicable in state court).

423. See id.

424. See JefF MADricK, The CASE FOR BIG GOVERnMENT 1 (2009) ("It is conventional wisdom in America today that high levels of taxes and government spending diminish America's prosperity. The claim strikes a deep intuitive chord, not only among those on the Right, but also among many on today's Left. It has become so obvious to so many over the last thirty years, it hardly seems to require demonstration any longer. It is apparently so widely accepted by the public and rolls off the tongues of policymakers from both parties with such fluency that one would think the evidence needn’t even be gathered.”); Andrew Edgecliffe-Johnson, Faith in Government Plummets, Research Says, Fin. TIMES, Jan. 23, 2012, at 6 ("The public's faith in government has dropped sharply around the world in the past year, giving businesses a rare opportunity to seize the global agenda .... [I]n every country, government leaders were more distrusted than business chiefs.”); Elizabeth Mendes, In U.S., Fear of Big Government at Near-Record Level, GALLUP.COM (Dec. 12, 2011), available at http://www.gallup.com/poll/151490/fear-big-government-near-record-level.aspx ("Two in three Americans (64\%) say big government will be the biggest threat to the country, one percentage point lower than the record high, and more than twice the number who say the same about big business (26\%).”).

425. See Marc Galanter, The Hundred-Year Decline of Trials and the Thirty Years War, 57 STAN. L. REV. 1255, 1266-67 (2005) ("Starting in the 1970s, large sections of business embraced beliefs and prescriptions about the legal system that, for want of a name, I have called the 'jaundiced 
Arbitration is enforced even under circumstances where reasonable persons might wonder about the degree of assent to boilerplate arbitration clauses in standardized contracts of adhesion.

Courts-particularly the Supreme Court-have tended to view arbitration as if it were still the type of guild-like expert resolution among merchants that animated support for the 1925 Federal Act while ignoring the degree to which post-Southland forms of mass consumer arbitration have moved far away from the original congressional intent and purpose. But to a large degree, the Court, when dealing with arbitration, has refused to bind itself to the type of textualism and originalism it ordinarily embraces in matters of statutory construction.

The Court's modern arbitration jurisprudence imposed a judicial evolution of the Act in which the statute morphed from one shielding the commercial contracts of merchants from overt judicial hostility into a statute allegedly enshrining a "liberal" and "national policy" in favor of arbitration so strong that-in spite of the language of section 2 of the Act-state contract law regulating the arbitration contracting process is largely preempted by the Act, even when applied to a variety of mandatory mass arbitration far afield from the dispute resolution envisioned by the enacting Congress.

In the process, the Court has been willing to ignore seemingly clear statutory text favorable to workers resisting mandatory arbitration of jobrelated disputes and to view traditional state contract regulation as some

view.' By this I refer to the view that America is enmeshed in a 'litigation explosion' that is unraveling the nation's social fabric and undermining the economy.... In the jaundiced view, trials are not only expensive, but risky because juries are arbitrary, sentimental, and 'out of control.' This view reinforces strategies of settlement to avoid trial.”) According to Galanter, "[w]hile confidence in adjudication and courts has declined, the courts, politicians, and business elites have embraced ADR.” Id. at 1268; accord, Arthur R. Miller, The Pretrial Rush to Judgment: Are the "Litigation Explosion," "Liability Crisis," and Efficiency Clichés Eroding Our Day in Court and Jury Trial Commitments?, 78 N.Y.U. L. REV. 982, 984-85 (2003) ("Critics maintain that excessive and frivolous litigation overwhelms the judicial system's capacity to administer speedy and efficient justice, leads to higher costs for litigants and society at large, and even hinders America's competitive position in the global economy.... Civil litigation has long been criticized as costly and inefficient.”); Deborah L. Rhode, Frivolous Litigation and Civil Justice Reform: Miscasting the Problem, Recasting the Solution, 54 DUKE L.J. 447, 475 (2004) ("Critics of the current system frequently present alternative dispute resolution (ADR) as an all-purpose prescription.”).

Anti-litigation sentiment has been in ascendency for some time. See Marc Galanter, The Day After the Litigation Explosion, 46 MD. L. REV. 3, 5 (1986) ("A phalanx of mournful and indignant commentators concur that America is in the throes of a litigation crisis requiring urgent attention from policymakers."); see also WALTER K. OLSON, THE LITIGATION EXPLOSION 2 (1991) (describing the "unleashing of litigation" that "clogs and jams the gears of commerce, sowing friction and distrust between the productive enterprises on which material progress depends and all who buy their products, work at their plants and offices, join in their undertakings”). 
sort of insurgency threatening federal power and the core of U.S. business.

This kind of adjudication is far removed from the traditional judicial commitment to fair reading of the text, close attention to legislative intent and purpose, and respect for traditional state authority. Even without considering the practical David versus Goliath aspects of many arbitration disputes and the practical consequences of enforced private ordering, the Court's arbitration jurisprudence has been so disappointing as to suggest undue infatuation with arbitration.

But in selected cases, the Court has been willing to disparage at least some aspects of some arbitrations, ${ }^{426}$ when necessary to prevent it from benefitting consumers or less powerful commercial actors. The Court has also been willing to permit mass-contract drafters wide latitude to arrogate to the arbitrator the traditional judicial role of assessing whether an arbitration agreement even covers the parties' dispute ${ }^{427}$ but has been unwilling to permit contracting parties to agree to subject arbitration awards to more searching scrutiny than provided by section $10 .{ }^{428}$

Perhaps the Court loves some things-for example, litigants with more money, power, or leverage - even more than it admires arbitration. Or perhaps it hates some things-for example, class actions, consumer demands, assertion of "anti-business" remedial legislation or common law-enough to restrict arbitration in some cases. But neither of these reasons provides any better justification for the Court's disappointing case law about arbitration than the Court's demonstrated infatuation with the arbitration mechanism.

True to this depressing form, the Court ushered in 2012 with yet another poorly reasoned valentine to arbitration in CompuCredit Corp. $v$. Greenwood, holding that "right to sue" and non-waiver provisions of the Credit Repair Organizations Act (CROA) $)^{429}$ did not preclude enforcement of a boilerplate mass arbitration clause. ${ }^{430}$ Distressingly, only Justice Ginsburg dissented, ${ }^{431}$ although Justices Sotomayor and

426. See supra text accompanying notes 355-74 (discussing Stolt-Nielsen and class-wide resolution of claims).

427. See supra text accompanying notes 375-85 (discussing Rent-A-Center and the expansion of arbitrators' authority).

428. See supra text accompanying notes 349-53 (discussing Hall Street and the inability of a contract to expand the scope of judicial scrutiny of arbitrations).

429. 15 U.S.C. § 1679 (2006).

430. CompuCredit Corp. v. Greenwood, 132 S. Ct. 665, 669-71 (2012).

431. Id. at 676 (Ginsburg, J., dissenting). 
Kagan in concurring opinions viewed the issue as "a much closer case than the majority opinion suggests." 432

CROA, passed in 1996, responded to a perceived problem of abusive lending and was designed to protect consumers dealing with "credit repair” lenders, in particular credit card companies that issued low-limit credit cards to persons with poor credit history. ${ }^{433}$ The limited options and sophistication of these bad-credit-risk consumers logically made them particularly vulnerable to predatory lending agreements. ${ }^{434}$

CompuCredit itself provided an almost textbook example of the potential for abuse of such credit card issuance. Plaintiff Greenwood was issued an "Aspire Visa" credit card marketed by CompuCredit and issued by a bank. ${ }^{435}$ Greenwood's complaint alleged that:

CompuCredit's promotional materials told potential customers that no deposit would be required, and that cardholders would receive, upfront, a credit line of $\$ 300$. In fact, plaintiffs asserted, they were charged an initial finance fee of $\$ 29$, a monthly fee of $\$ 6.50$, and an annual fee of $\$ 150$, assessed immediately against the $\$ 300$ limit. In the aggregate, Plaintiffs calculated, fees charged the first year amounted to $\$ 257 .{ }^{436}$

When Greenwood sued and sought class action treatment of the case, she was confronted with the broad-based arbitration clause used in an "enclosed insert" to the application materials, which provided for arbitration before the controversial National Arbitration Forum (NAF) that has since been forced from this segment of the arbitration market by a state attorney general's action. ${ }^{437}$

CROA mandates certain disclosures by card marketers such as CompuCredit, including a statement to the consumer that "[y]ou have a right to sue" ${ }^{338}$ and also makes void "[a]ny waiver by any consumer of any protection provided by or any right of the consumer" under the law. ${ }^{439}$ Continuing the Court's departure from the normal rules of statutory construction when faced with a challenge to arbitration, the

432. Id. at 675 (Sotomayor, J., concurring).

433. See Andrew T. Schwenk, A Beast of Burden Without Any Reins, 76 BROOK. L. REV. 1165, 1180-81 (2011).

434. See id.

435. CompuCredit, 132 S. Ct. at 667.

436. Id. at 676 (Ginsburg, J., dissenting).

437. See id. at $677 \mathrm{nn} .1-2$; supra note 102 (discussing the NAF’s settlement with the Minnesota Attorney General).

438. See 15 U.S.C. § 1679c(a) (2006).

439. See § $1679 f$. 
Court ruled that the "right to sue" disclosure did not literally mean what it said and meant only a right to make a claim-which could in turn be subject to a forum selection clause like an arbitration agreement, even one found in a package insert to an adhesion contract designating a tribunal thought by many to be stacked against consumers. ${ }^{440}$

Only a half-year after its controversial and much-criticized 5-4 split in Concepcion, ${ }^{441}$ the Court returned with a vengeance to supporting arbitration, even in the face of seemingly contrary statutory directives and problematic "consent" to an arbitration provision that severely limited the opportunity for vindication of small claims. But perhaps even worse, the Court's latest embrace of arbitration spurred only one dissenting vote. ${ }^{442}$ However tainted, the Court's love for arbitration continues unabated.

440. See $131 \mathrm{~S}$. Ct. at $669-70$. The majority attempted to bolster its argument by noting that Congress has in other instances used more express language precluding arbitration and posited that, by 1996, Congress was well aware of concerns about mandatory arbitration. See id. at 672 (majority opinion) (citing Ware, supra note 315).

The majority also relied on cases that refused to apply a "statutory exception" to arbitration, $i d$., but none of the statutes involved in those cases contained nonwaiver provisions, a point well made by the dissent. See id. at 679 (Ginsburg, J., dissenting).

441. Battles continue over Concepcion. See Scott Graham, AT\&T Mobility Doesn't Apply in the Workplace, Says NLRB, CORP. COUNSEL, Jan. 9, 2012, available at http://www.law.com/jsp/cc/ PubArticleCC.jsp?id=1202537751118 ("NLRB member Craig Becker joined chairman Mark Gaston Pearce (both Obama appointees to the Board) to hold that class action waivers don't belong in the workplace, and that requiring them as a condition of employment is an unfair labor practice. The Board's sole Republican member, Brian Hayes, was recused for undisclosed reasons.”).

442. Media reports of the CompuCredit decision not only portrayed the vote as lopsided and the result as uncontroversial, but they generally failed to discuss Justice Ginsburg's dissenting rationale and counter statement regarding statutory text, structure, and purpose. See, e.g., Debra Cassens Weiss, Supreme Court Upholds Arbitration Provision in Credit Card Contract, A.B.A. J., Jan. 10, 2012, available at http://www.abajournal.com/news/article/supreme_court_upholds_arbitration_ provision_in_credit_card_contract (reporting that Justice “Ginsburg was the only dissenter”); Supreme Court Upholds Credit Card Arbitration Clauses, INS. J., Jan. 12, 2012, available at http://www.insurancejournal.com/news/national/2012/01/12/230946.htm (same). 